\section{Arrkivoc

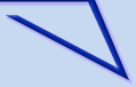

Archive for

Organic Chemistry
The Free Internet Journal

for Organic Chemistry
Review

Arkivoc 2017, part i, 148-201

\title{
Recent applications of isatin in the synthesis of organic compounds
}

\author{
Razieh Moradi, ${ }^{a}$ Ghodsi Mohammadi Ziarani, ${ }^{* a}$ and Negar Lashgari ${ }^{b}$ \\ ${ }^{a}$ Department of Chemistry, Alzahra University, Tehran, Iran \\ ${ }^{b}$ School of Chemistry, College of Science, University of Tehran, Tehran, Iran \\ E-mail:gmziarani@hotmail.com gmohammadi@alzahra.ac.ir
}

\section{Abstract}

Isatin has been used in design and synthesis of diverse types of heterocyclic and carbocyclic compounds and considered as a valuable building block in organic synthesis. There is a diversity of multicomponent reactions of this useful reagent. This article aims to review the advances in the use of isatin as starting material in the synthesis of various organic compounds and drugs up to June 2016.

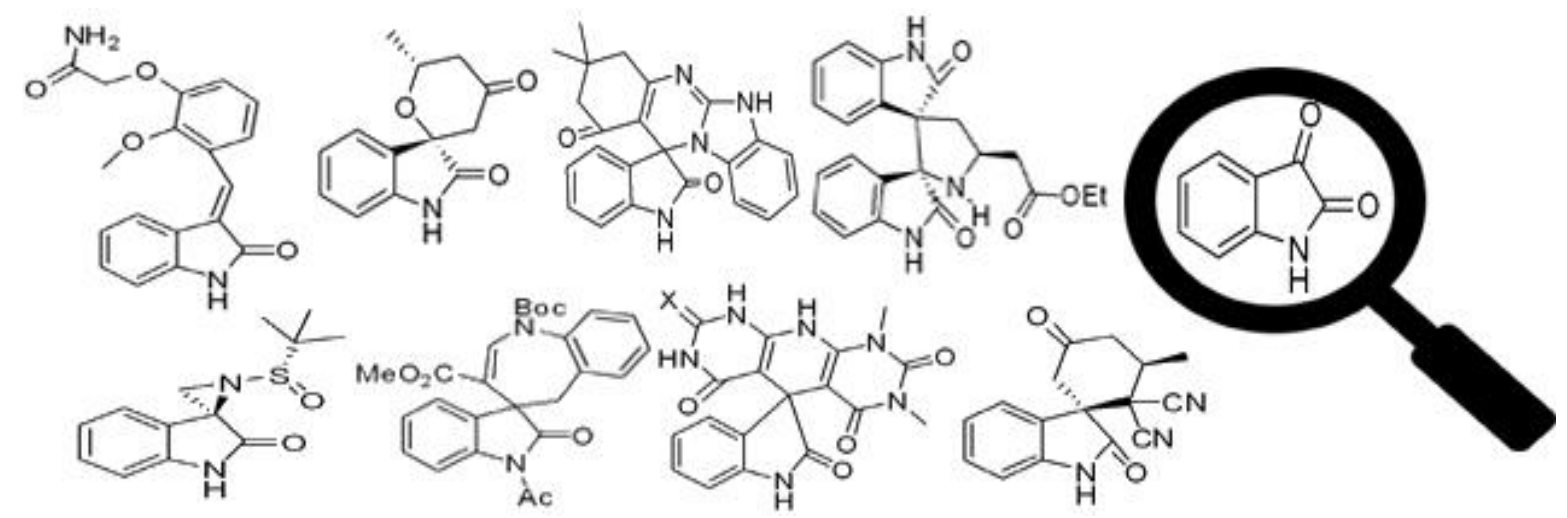

Keywords: Isatin, organic compounds, heterocyclic compounds, carbocyclic compounds 


\section{Table of Contents}

1. Introduction

2. Reactions at the C-3 Position of Isatin

3. Synthesis of Isatin-based Spiro-fused Heterocyclic Frameworks

3.1 Synthesis involving two-component reactions of isatins

3.1.1 Three-membered heterocycles

3.1.2 Five-membered heterocycles

3.1.3 Six-membered heterocycles

3.1.4 Seven-membered heterocycles

4. Synthesis Involving Multicomponent Reactions

4.1 Three-membered heterocycles

4.2 Five-membered heterocycles

4.3 Six-membered heterocycles

4.4 Seven-membered heterocycles

5. Synthesis of Isatin-based Spiro-fused Carbocyclic Frameworks

6. Miscellaneous Reactions

7. Conclusions

Acknowledgements

Abbreviations

References

\section{Introduction}

Isatin was first obtained by Erdmann ${ }^{1}$ and Laurent ${ }^{2}$ in 1840 as a product of the oxidation of indigo dye by nitric acid and chromic acid. Isatin is one of the most important heterocyclic compounds. For example, Schiff bases of isatin are used for their pharmaceutical properties. ${ }^{3}$ Oxindole as an isatin derivative represents an important class of heterocyclic compounds endowed of interesting pharmacological $\left.\right|^{4,5}$ and biological activities such as antimicrobial, ${ }^{6}$ antitumor, ${ }^{7,8}$ antitubercular, ${ }^{9,10}$ antimalaria, ${ }^{11}$ anti-HIV ${ }^{12}$ and antibacterial activities. ${ }^{13}$ On the other hand, the chiral 3,3-disubstituted oxindole framework is a privileged motif found in various natural products and pharmaceutically active compounds. ${ }^{14}$ As a class of important 3,3-disubstituted oxindoles, 3-substituted 3-hydroxyindolin-2-ones have attracted considerable attention because of their diverse biological activities. ${ }^{15,16}$

During recent years several review articles were published on isatins. Singh and Desta reviewed isatin as a privileged molecule in design and synthesis of spiro-fused cyclic frameworks. ${ }^{17}$ Synthesis of spiro ${ }^{18}$ and multispiro ${ }^{19}$ heterocyclic compounds from isatin were studied by Borad et al. The enantioselective reactions of isatin were also the subject of several review articles. ${ }^{20-22}$ Herein, in continuation of our studies towards isatin, ${ }^{23-25}$ and since there is a wide range of reactions that include isatin in the synthesis of organic compounds, this review presents the recent applications of isatin in the synthesis of different types of organic compounds up to June 2016.

\section{Reactions at the C-3 Position of Isatin}

The direct asymmetric aldol reaction between isatin derivatives 1 and acetone 2 at $-35^{\circ} \mathrm{C}$ in EtOH using $\mathrm{N}$ - 
arylprolinamides has been developed and the corresponding aldol products 3 were obtained (Scheme 1). ${ }^{26}$ The same authors used trans-4-hydroxy-L-prolinamide as a catalyst in this reaction. ${ }^{27}$ In a similar reaction, $\alpha$ cross-coupling aldol addition of activated olefins $\mathbf{4}$ with isatins $\mathbf{1}$ has been described in the presence of ruthenium(III) chloride and tributyltin hydride (TBTH) at room temperature to afford 3-substituted-3-hydroxy2-oxindoles 5 (Scheme 1). ${ }^{28}$

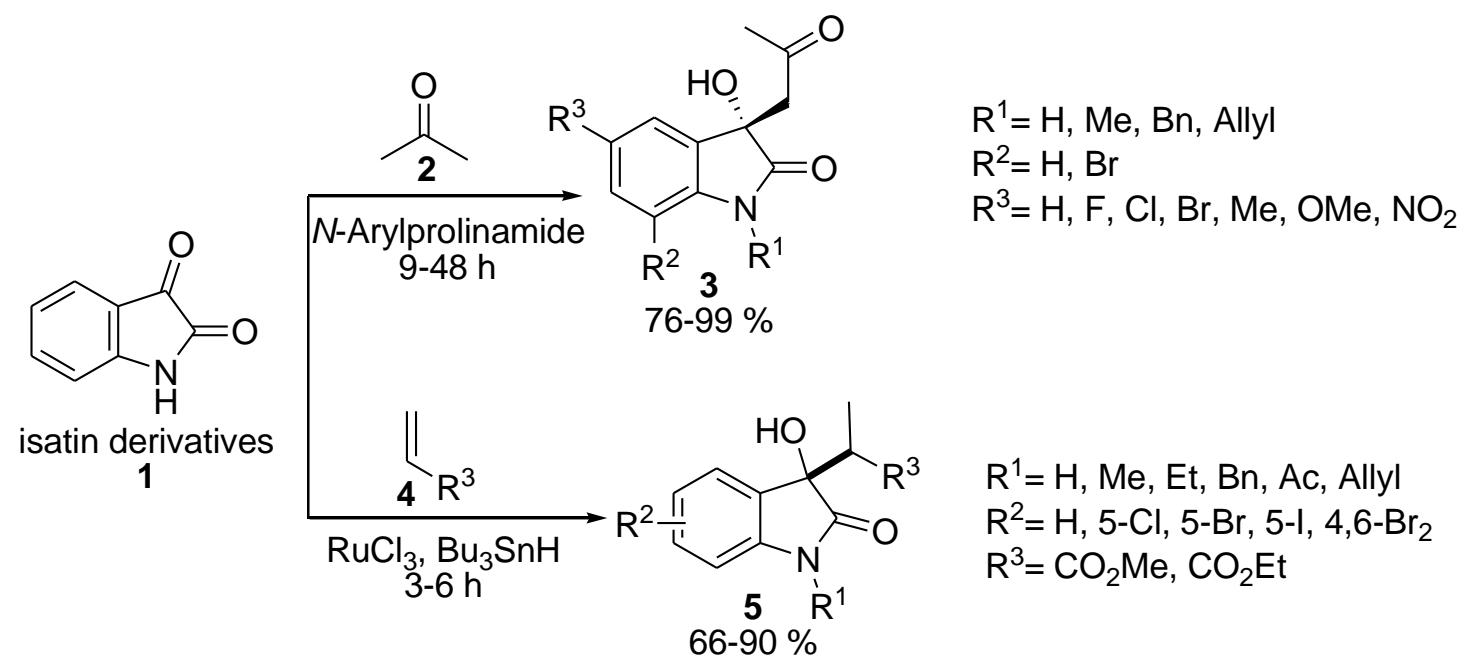

\section{Scheme 1}

The vinylation of isatins 1 by vinyl boronic acids 6 catalyzed by $\mathrm{CoBr}_{2}$ in the presence of DuanPhos was reported for the synthesis of the tertiary allylic alcohols 7 (Scheme 2 ). ${ }^{29}$

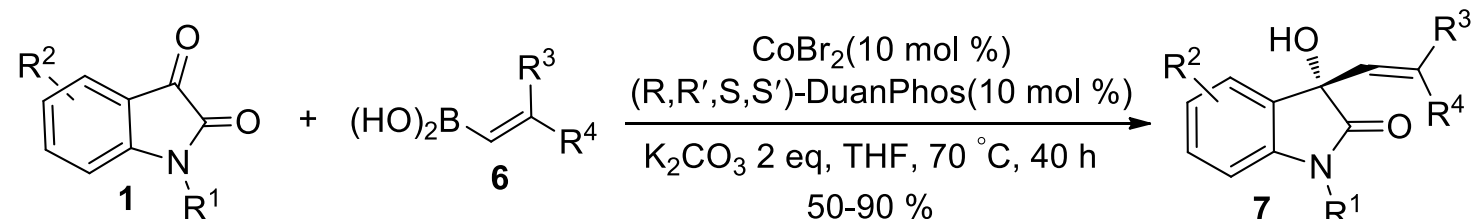

$\mathrm{R}^{1}=\mathrm{H}, \mathrm{Cl}, \mathrm{Me}, \mathrm{Bn}, \mathrm{PMB}$

$\mathrm{R}^{2}=\mathrm{H}, 5-\mathrm{Cl}, 5-\mathrm{I}, 5-\mathrm{Me}, 5-\mathrm{OMe}, 5-\mathrm{OCF}_{3}, 7-\mathrm{Cl}$

$\mathrm{R}^{3}=\mathrm{C}_{6} \mathrm{H}_{5}, \mathrm{Me}, 4-\mathrm{ClC}_{6} \mathrm{H}_{4}, 4-\mathrm{FC}_{6} \mathrm{H}_{4}, 4-\mathrm{MeC}_{6} \mathrm{H}_{4}$ $\mathrm{R}^{4}=\mathrm{H}, \mathrm{Me}$

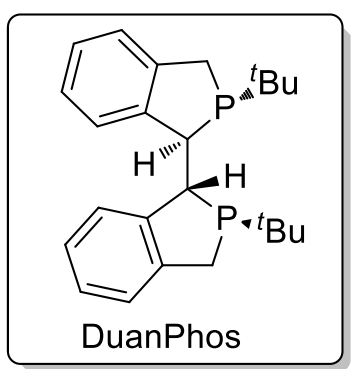

\section{Scheme 2}

The alkynylation reaction of isatins 1 and aryl-substituted alkynes 8 in the presence of bifunctional guanidine/Cul as catalyst was accomplished for the synthesis of 3-substituted 3-hydroxyoxindole scaffolds 9 (Scheme 3). ${ }^{30}$ In another study, zink dust was also used as catalyst in this reaction. ${ }^{31}$ 


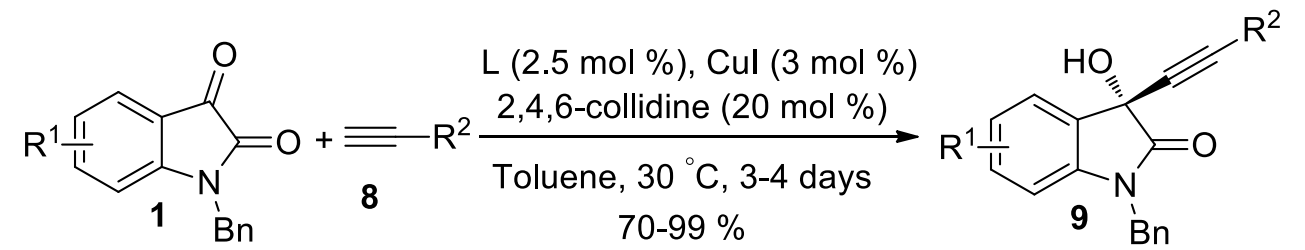

$\mathrm{R}^{1}=\mathrm{H}, 4-\mathrm{Cl}, 5-\mathrm{F}, 5-\mathrm{Br}, 5-\mathrm{I}, 5-\mathrm{MeOO}, 5-\mathrm{CF}_{3} \mathrm{O}$,

7-F, 7-Br, 7-Cl, 7-I, 7-- $\mathrm{CF}_{3}, 7-\mathrm{CF}_{3} \mathrm{O}$

$\mathrm{R}^{2}=2-\mathrm{FC}_{6} \mathrm{H}_{4}, 3-\mathrm{FC}_{6} \mathrm{H}_{4}, 4-\mathrm{FC}_{6} \mathrm{H}_{4}, 3-\mathrm{ClC}_{6} \mathrm{H}_{4}$,

3- $\mathrm{MeC}_{6} \mathrm{H}_{4}, 4-\mathrm{MeC}_{6} \mathrm{H}_{4}$, 3- $\mathrm{MeOC}_{6} \mathrm{H}_{4}$,

$\mathrm{CH}_{2} \mathrm{C}_{6} \mathrm{H}_{4}, \mathrm{CH}_{2} \mathrm{OCOEt}, \mathrm{CH}_{2} \mathrm{OCOPh}, \mathrm{CH}_{2} \mathrm{O}^{t} \mathrm{Bu}$,

$\mathrm{CH}_{2} \mathrm{NHBoc},{ }^{i} \mathrm{Pr}$, cyclopropyl, ${ }^{n} \mathrm{C}_{5} \mathrm{H}_{11},{ }^{n} \mathrm{C}_{10} \mathrm{H}_{21}$,

cyclopentyl, cyclohexyl, propenyl, octynyl,

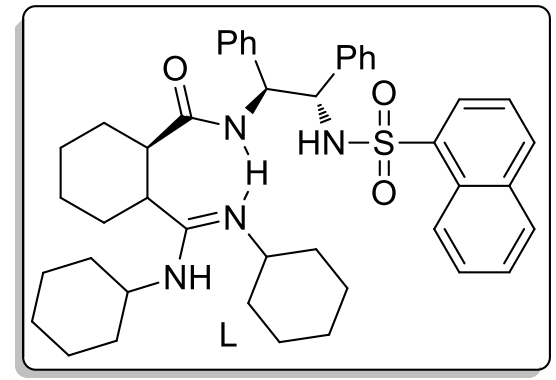

2-methylisoindolinyl-1,3-dione

\section{Scheme 3}

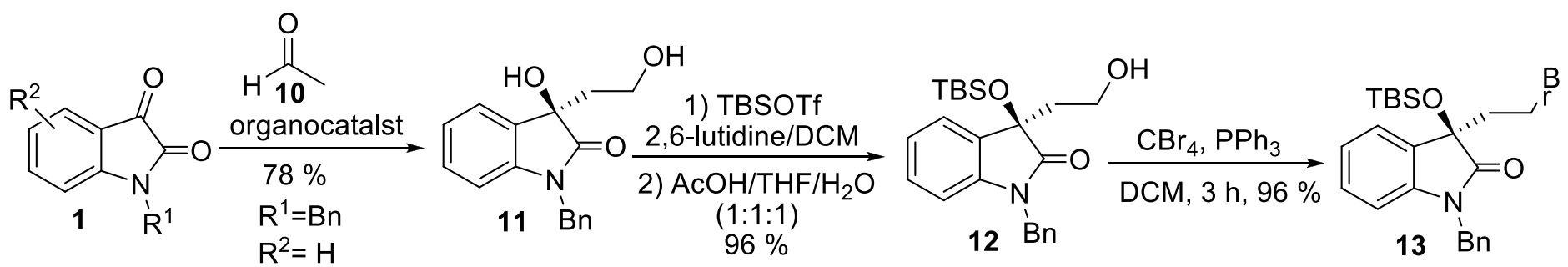

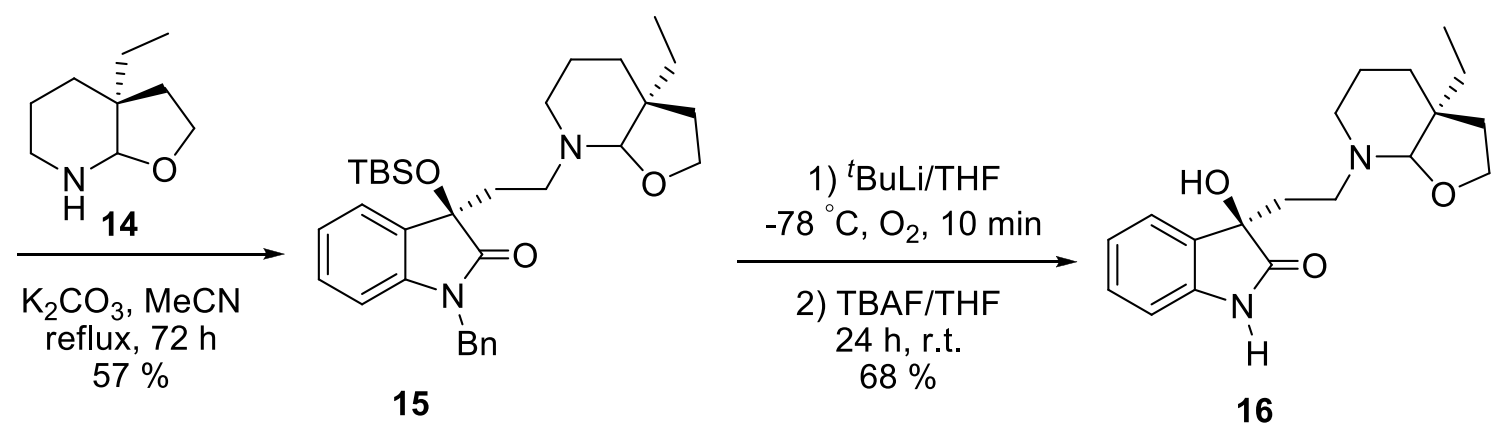

leucolusine<smiles>[R]c1ccc2c(c1)C(=O)C(=O)N2[R1]</smiles>

$\mathrm{R}^{1}=\mathrm{H}$

$\mathrm{R}^{2}=\mathrm{H}, 5-\mathrm{Me}, 5-\mathrm{MeO}, 5-\mathrm{F}, 5-\mathrm{Cl}$,

5,7-- $\mathrm{Me}_{2}, 4,6-\mathrm{Br}_{2}, 6-\mathrm{Br}, 7-\mathrm{Me}$,

7-Cl, 6,7-- $\mathrm{Me}_{2}, 6-\mathrm{Cl}-7-\mathrm{Me}$

$\mathrm{R}^{3}=\mathrm{H}, \mathrm{Me}, \mathrm{CH}_{2} \mathrm{OAC}$

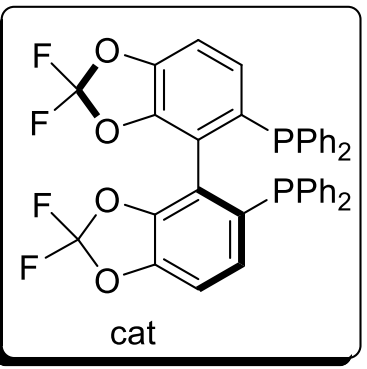

\section{Scheme 4}


The diastereoselective total synthesis of leucolusine $\mathbf{1 6}$ was described by the coupling of enantioenriched $(R)$-1-benzyl-3-(2-bromoethyl)-3-((tert-butyldimethylsilyl)oxy)indolin-2-one 13 with 14, which gave 15 in $57 \%$ yield (Scheme 4). ${ }^{32}$ Precursor 13 was prepared from 12 that obtained from 3-alkyl-3-hydroxyindolin-2-one 11 by the known organocatalytic cross-aldol reaction between acetaldehyde 10 and $\mathrm{N}$-benzylisatin $\mathbf{1}$. Global deprotection of 15 using ${ }^{t} \mathrm{BuLi} / \mathrm{O}_{2}$ in THF at $-78{ }^{\circ} \mathrm{C}$ followed by treatment with TBAF led to the formation of natural leucolusine 16 with 68\% isolated yield. In another study, the 3-allyl-3-hydroxyoxindoles 18 were obtaind from allylation reaction of isatin derivatives $\mathbf{1}$ and allyltrimethylsilane $\mathbf{1 7}$ using the (S)-difluorophos derived chiral $\mathrm{Hg}(\mathrm{OTf})_{2}$ complex as a catalyst (Scheme 4). ${ }^{33}$

The diastereo- and enantio-selective aldol addition of allenic esters 19 to isatins 1 in the presence of $\mathrm{AuCl}_{3}$ and chiral $N, N^{\prime}$-dioxide has been reported for the synthesis of the carbinol allenoates 20 (Scheme 5). ${ }^{34}$ The decrease in yield and enantioselectivity was mainly due to the steric hindrance of vicinal 4-substituted bulky halogen atoms (4-Cl, 4-Br). 5,7-Dimethyl-substituted isatin provided the best enantioselectivity.

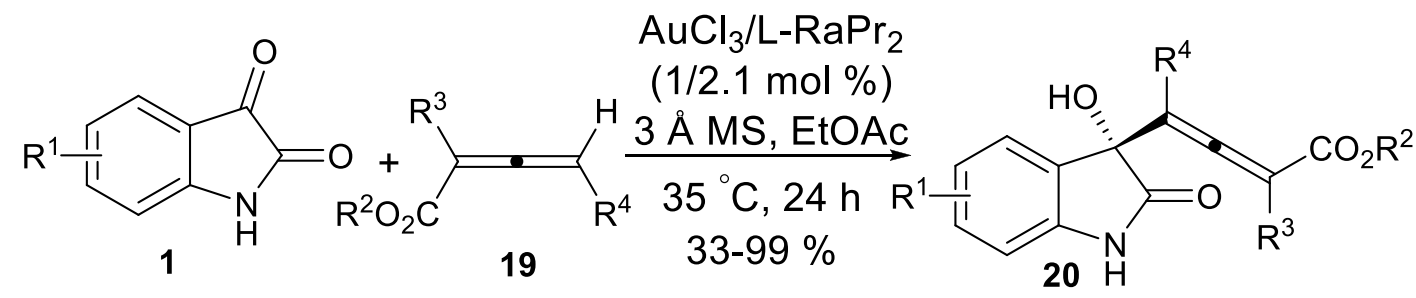

$\mathrm{R}^{1}=4-\mathrm{Cl}, 4-\mathrm{Br}, 5-\mathrm{F}, 5-\mathrm{Br}, 5-\mathrm{I}$, 5-Me, 5-MeO, 5- $\mathrm{CF}_{3} \mathrm{O}, 5,7-\mathrm{Me}_{2}$, 6-Br, 7-F, 7-Br, 7-CF $\mathrm{R}^{2}=\mathrm{Me}, \mathrm{Et}, \mathrm{Bn}, \mathrm{Ph},{ }^{i} \mathrm{Pr},{ }^{t} \mathrm{Bu}$ $\mathrm{R}^{3}=\mathrm{H}, \mathrm{Bn}, \mathrm{Et},{ }^{i} \mathrm{Bu}, i$-pentyl, n-decyl, 2- $\mathrm{MeC}_{6} \mathrm{H}_{4} \mathrm{CH}_{2}, 4-\mathrm{MeC}_{6} \mathrm{H}_{4} \mathrm{CH}_{2}$, 3- $\mathrm{FC}_{6} \mathrm{H}_{4} \mathrm{CH}_{2}, \mathrm{EtO}_{2} \mathrm{CCH}_{2}$ $\mathrm{R}^{4}=\mathrm{H}, \mathrm{Me}, \mathrm{Et}, \mathrm{Bn}, \mathrm{Ph}, n$-decyl

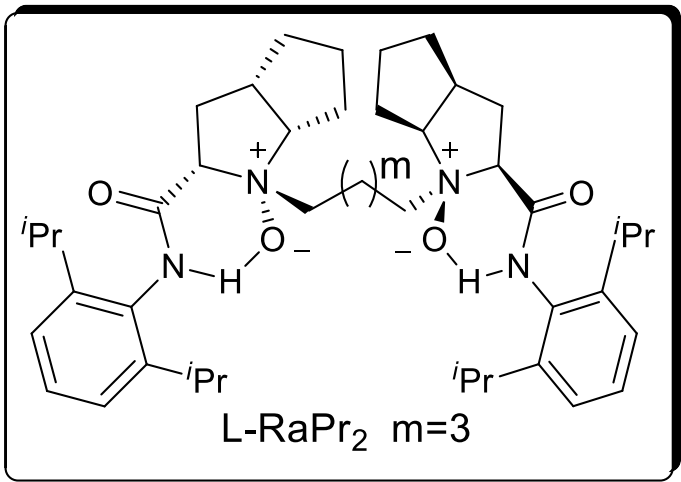

\section{Scheme 5}

A series of 3-hydroxy-7-aza-2-oxindoles $\mathbf{2 3}$ have been synthesized in good yields and moderate to high enantioselectivity via the enantioselective Morita-Baylis-Hillman (MBH) reaction of 7-azaisatins 21 with maleimides $\mathbf{2 2}$ in the presence of bifunctional tertiary amine, $\beta$-isocupreidine ( $\beta-I C D)$ as the catalyst (Scheme 6). ${ }^{35}$

Shankaraiah's group designed the synthesis of new (Z)-3-(3'-methoxy-4'-(2-amino-2oxoethoxy)benzylidene)indolin-2-one derivatives $\mathbf{2 5}$ from the Knoevenagel condensation reaction of isatin derivatives 1 and 3-methoxy-4-(2-amino-2-oxoethoxy)-benzaldehydes 24 (Scheme 7). ${ }^{36}$ The products were evaluated for their cytotoxic activity against selected human cancer cell lines of prostate (PC-3 and DU-145), breast (BT-549 and MDA-MB-231) and non-tumorigenic prostate epithelial cells (RWPE-1). 
<smiles>[R]c1cnc2c(c1)C(=O)C(=[OH+])N2[Z17]</smiles>

$\mathrm{R}^{1}=\mathrm{Me}, \mathrm{Ph}, \mathrm{Bn}, 4-\mathrm{ClC}_{6} \mathrm{H}_{5}, \mathrm{MOM}$

$\mathrm{R}^{2}=\mathrm{H}, \mathrm{Cl}, \mathrm{Br}, \mathrm{Ph}$

$\mathrm{R}^{3}=\mathrm{Ph}, \mathrm{Me}, \mathrm{Bn},{ }^{n} \mathrm{Bu}$, cyclohexyl, 4- $-\mathrm{MeC}_{6} \mathrm{H}_{4}$,

4- $\mathrm{MeOC}_{6} \mathrm{H}_{4}, 4-\mathrm{ClC}_{6} \mathrm{H}_{4}, 2,4,6-\mathrm{Me}_{3} \mathrm{C}_{6} \mathrm{H}_{2}$

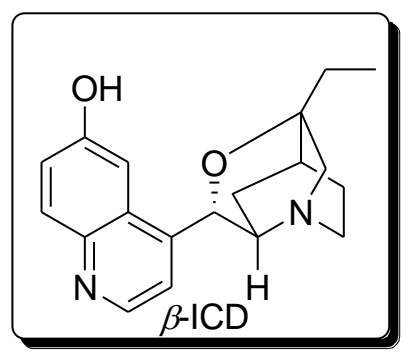

\section{Scheme 6}

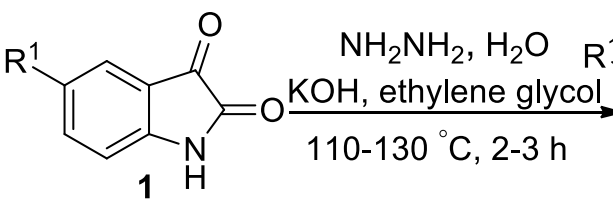

$\mathrm{R}^{1}=\mathrm{H}, \mathrm{F}, \mathrm{Cl}, \mathrm{Br}, \mathrm{Me}$

$N R^{2} R^{3}=$ morpholino, piperidine-1-yl, indolin-1-yl, 2,6-dimethylmorpholin

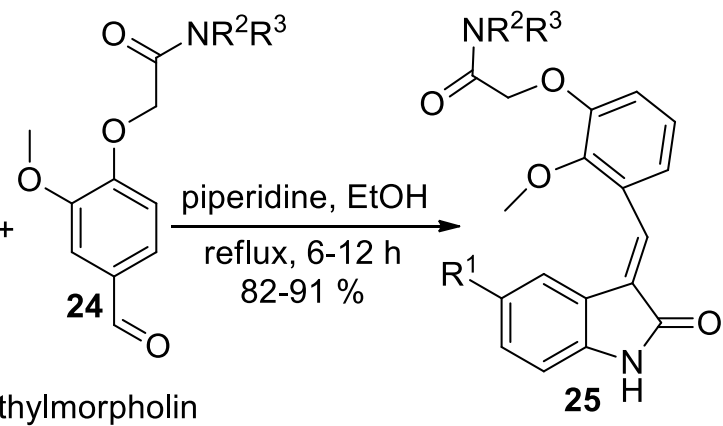

$25 \mathrm{H}$

\section{Scheme 7}

Shaker and Marzouk investigated the condensation of isatin $\mathbf{1}$ with acetohydrazide 26 to yield the oxoindolinylidene $\mathbf{2 7}$ (Scheme 8). ${ }^{37}$ The newly prepared compound was tested in vitro against a panel of four human tumor cell lines, namely hepatocellular carcinoma (liver) HePG-2, colon cancer HCT-116, human prostate cancer PC3, and mammary gland breast MCF-7. It was also tested as an antioxidant.<smiles>NNC(=O)CN1N=C([Al])CCC1=O</smiles>

$\mathrm{Ar}=4-\mathrm{ClC}_{6} \mathrm{H}_{4}, 3-\mathrm{MeC}_{6} \mathrm{H}_{4}$

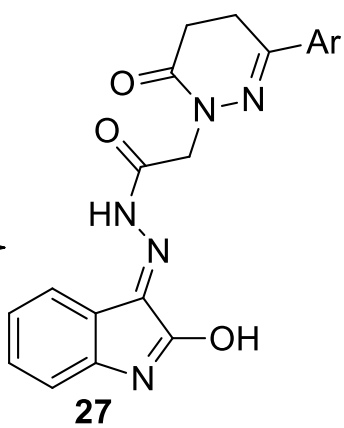

\section{Scheme 8}


Terada's group developed a methodology based on the two-step sequence strategy for the synthesis of 3arylisatin derivatives $\mathbf{3 0}$ from the isatin derivatives $\mathbf{1}$ and aryl boron salts $\mathbf{2 9}$. The methodology involves the formation of an oxindole having a phosphate moiety $\mathbf{2 8}$ at the C-3 position via the [1,2]-phospha-Brook rearrangement under Brønsted base catalysis and the subsequent palladium-catalyzed cross-coupling reaction with aryl boron 29 reagents (Scheme 9). ${ }^{38}$

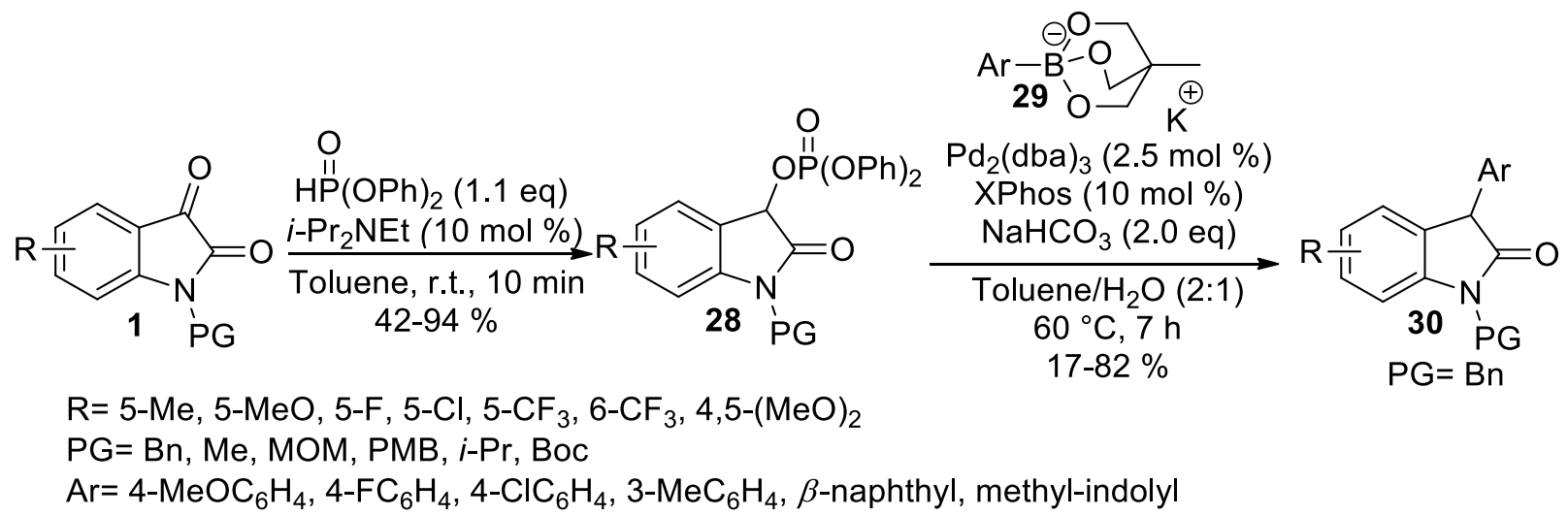

\section{Scheme 9}

Bajaj and co-workers reported the use of macrocyclic Ti(IV)-salen complexes as catalysts for enantioselective hydrophosphonylation (EHP) reaction of isatin derived ketimines $\mathbf{3 1}$ with diphenyl phosphate 32 as nucleophile. The corresponding phosphonylated products $\mathbf{3 3}$ were obtained in high enantioselectivity (ee up to 99\%) (Scheme 10). ${ }^{39}$

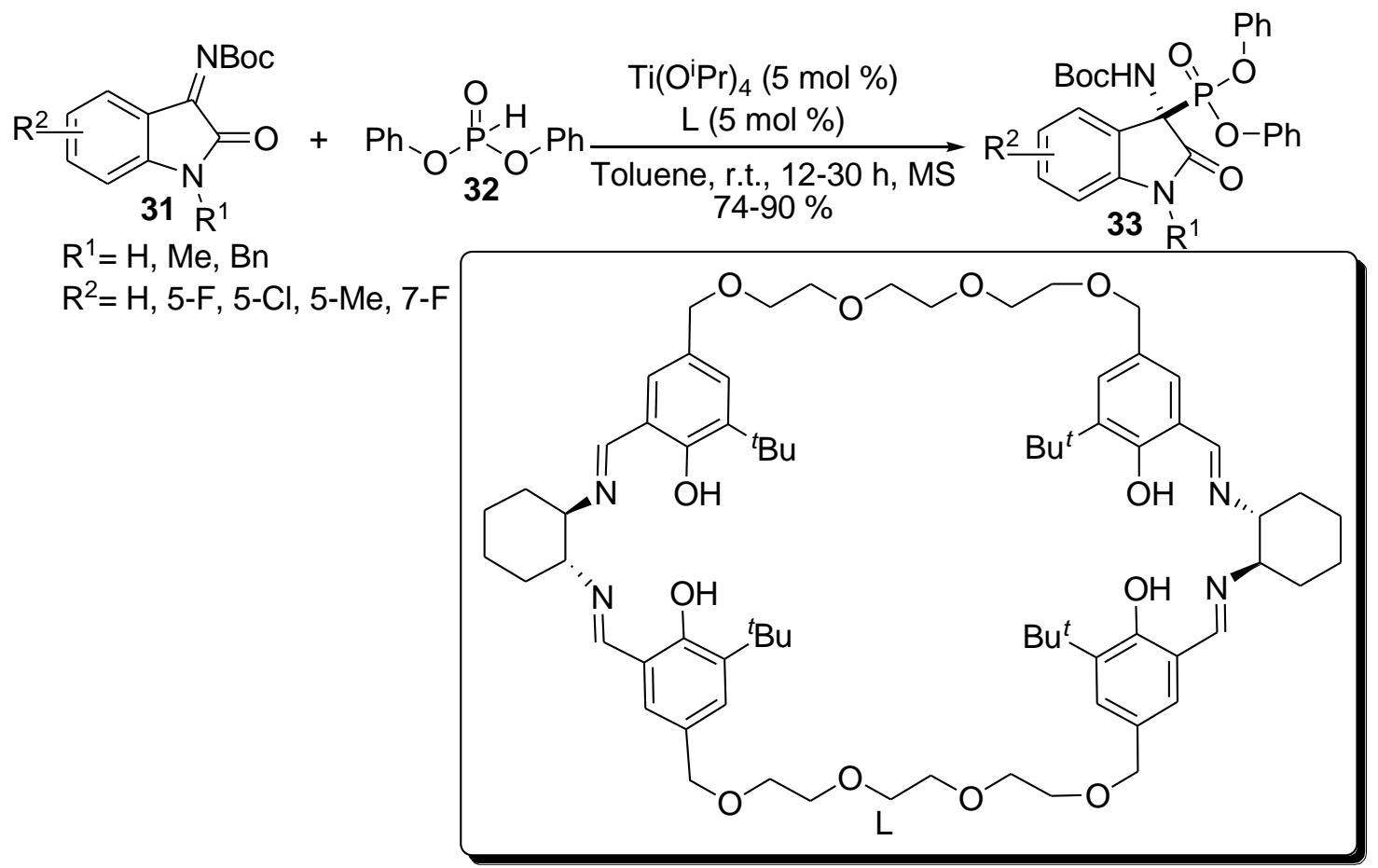

\section{Scheme 10}


In another study, Su and Xu developed the synthesis of optically pure 2-oxoindolinyl- $\beta^{3,3}$-amino esters 36 in good yields via the diastereoselective asymmetric Reformatsky-type reaction of isatin-derived chiral $N$ sulfinyl ketimines 34 with ethyl bromoacetate 35 (Scheme 11). ${ }^{40}$

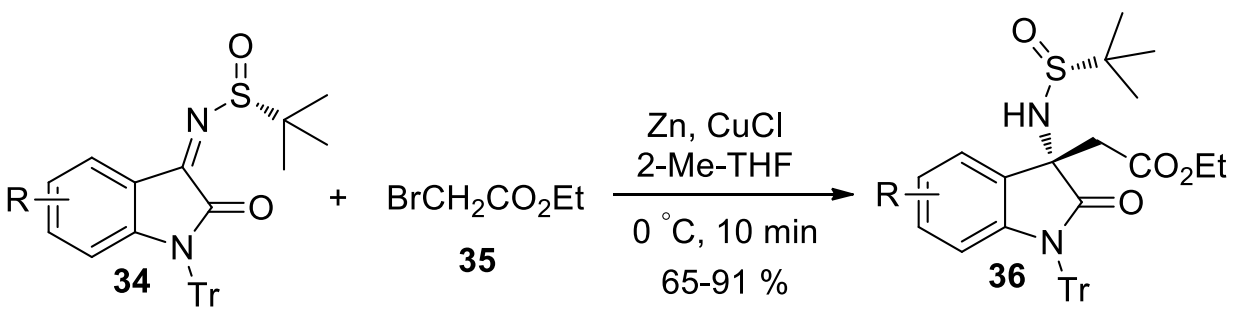

$\mathrm{R}=\mathrm{H}, 5-\mathrm{F}, 5-\mathrm{Cl}, 5-\mathrm{Br}, 5-\mathrm{I}, 5-\mathrm{Me}, 5-\mathrm{MeO},{ }^{i}{ }^{\mathrm{Pr}}, 6-\mathrm{Cl}, 6-\mathrm{Br}, 7-\mathrm{F}, 4,6-\mathrm{F}_{2}, 5-\mathrm{F}-6-\mathrm{MeO}$

\section{Scheme 11}

Kureshy's group synthesized the $\beta$-nitro amines $\mathbf{3 8}$ from the asymmetric aza-Henry reaction of various isatin derived $\mathrm{N}$-Boc ketimines $\mathbf{3 1}$ with nitromethanes $\mathbf{3 7}$ in the presence of the chiral $\mathrm{Cu}(I I)$ dimeric macrocyclic salen complex as catalyst (ee, up to 99\%). This protocol was also used for the synthesis of enantiomerically pure (S)- $\beta$-diamines $\mathbf{3 9}$ via asymmetric aza-Henry reaction of $N$-Boc ketimine $\mathbf{3 1}$ in two steps in good yield and high enantioselectivity (Scheme 12). ${ }^{41}$

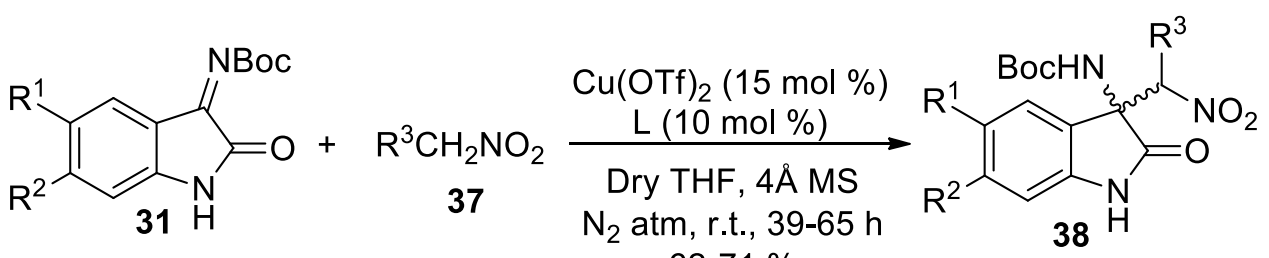

$62-71 \%$

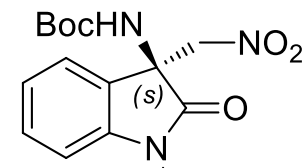

38

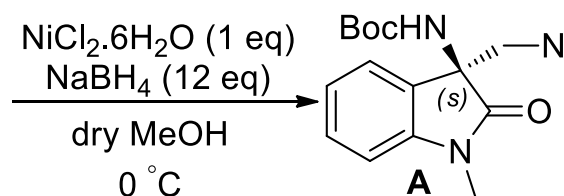

$\underset{\mathrm{Et}_{2} \mathrm{O}-\mathrm{MeOH}}{\stackrel{\mathrm{HCl}}{\longrightarrow}}$<smiles>CN1C(=O)[C@](N)(CN)c2ccccc21</smiles>

$\mathrm{R}^{1}=\mathrm{H}, \mathrm{Cl}$

$\mathrm{R}^{2}=\mathrm{H}, \mathrm{Br}$

$\mathrm{R}^{3}=\mathrm{Me},{ }^{n} \mathrm{Bu}, \mathrm{Me}_{2}$

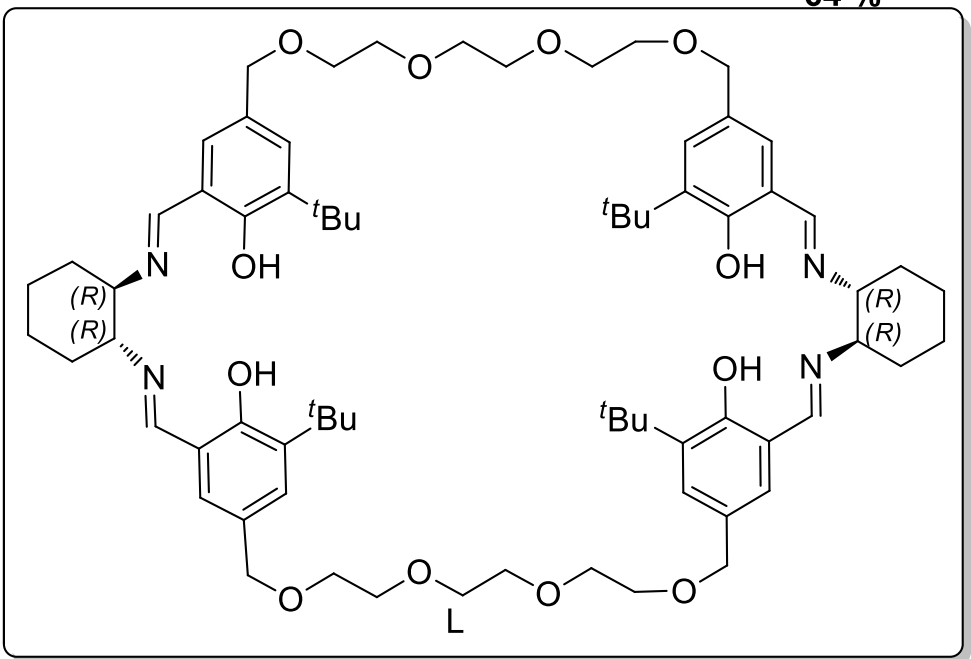


Pedro's group reported the enantioselective addition of 4-substituted pyrazolones $\mathbf{4 0}$ to isatin-derived ketimines 31. In this study, the authors used a bifunctional organocatalyst (a quinine-derived thiourea) to provide a variety of chiral heterocyclic compounds containing both aminooxindole and pyrazolone moieties bearing vicinal quaternary stereocenters 41 (Scheme 13)..$^{42,43}$

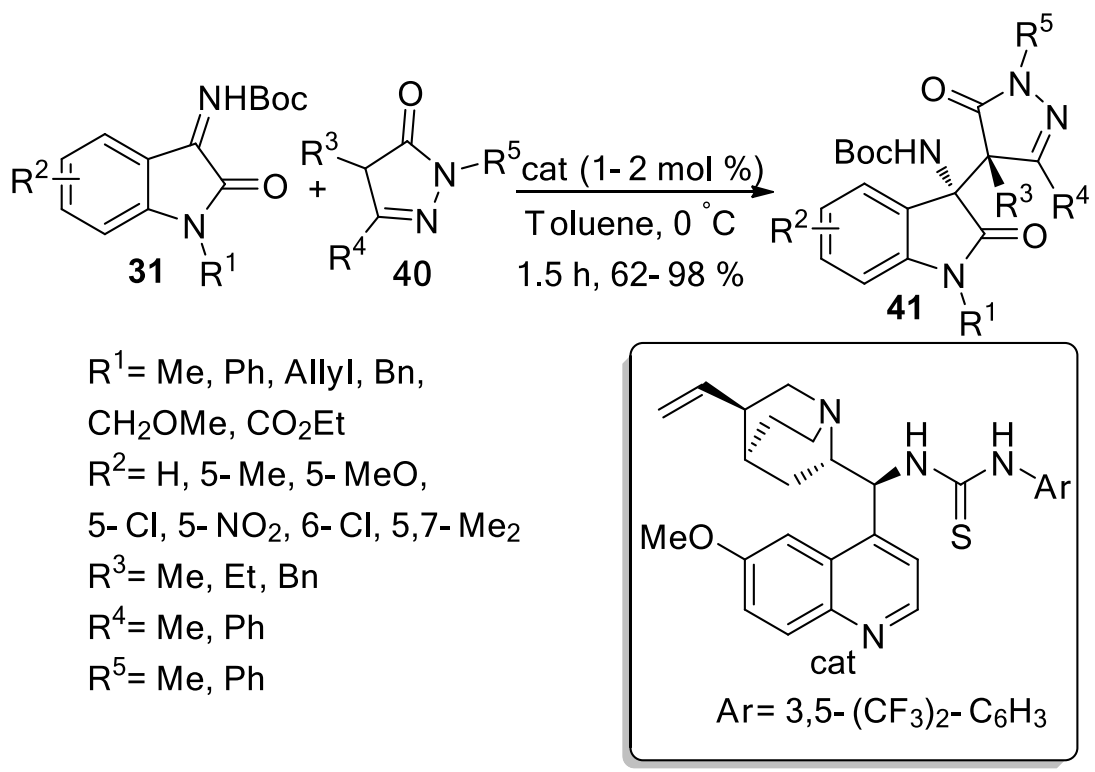

\section{Scheme 13}
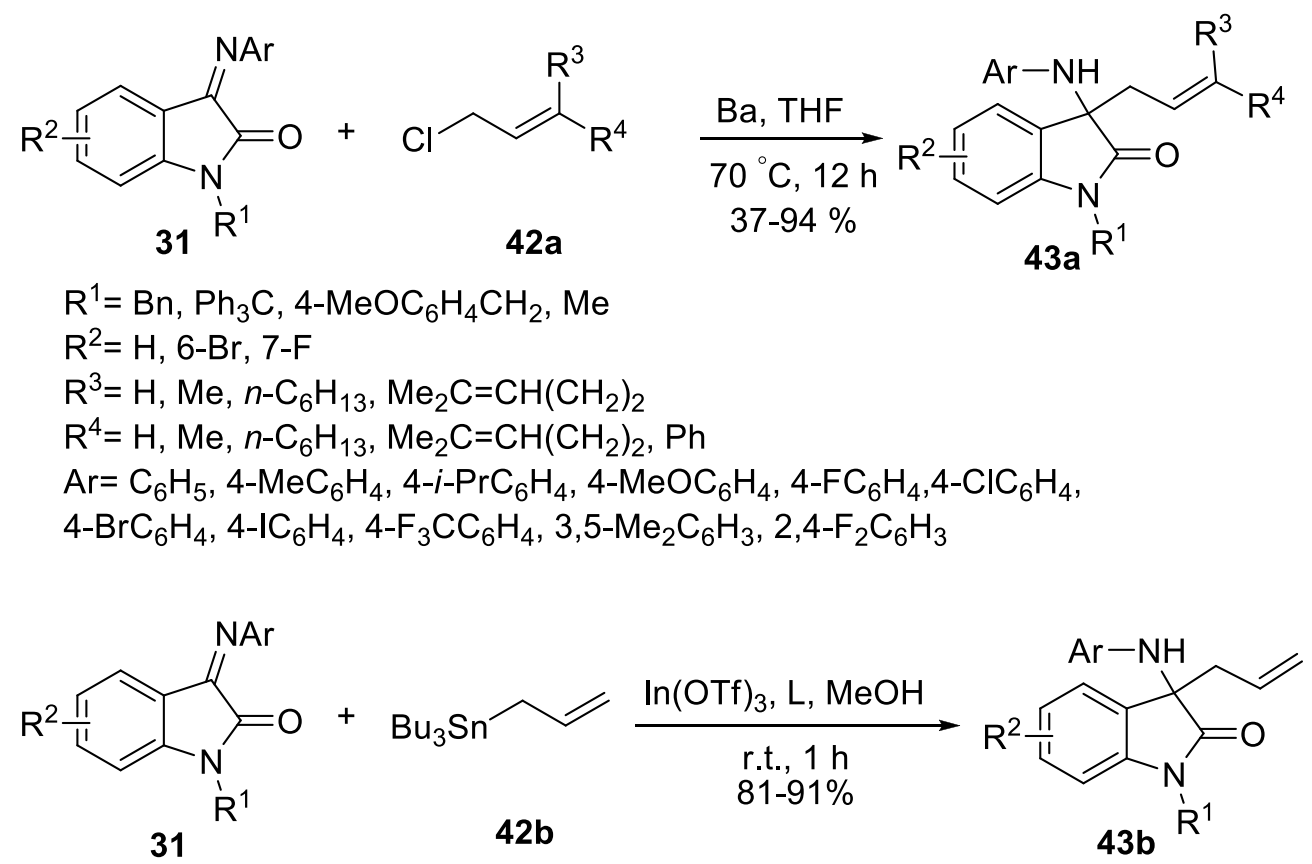

$\mathrm{R}^{1}=\mathrm{H}, \mathrm{Me}, \mathrm{Ph}, \mathrm{Bn}$

$\mathrm{R}^{2}=\mathrm{H}, 5-\mathrm{Me}, 5-\mathrm{MeO}, 5-\mathrm{Cl}, 6-\mathrm{Cl}, 7-\mathrm{Cl}$

$\mathrm{Ar}=\mathrm{C}_{6} \mathrm{H}_{5}, 2-\mathrm{MeC}_{6} \mathrm{H}_{4}, 3-\mathrm{MeC}_{6} \mathrm{H}_{4}, 4-\mathrm{MeOC}_{6} \mathrm{H}_{4}$, $4-\mathrm{NO}_{2} \mathrm{C}_{6} \mathrm{H}_{4}, 4-\mathrm{ClC}_{6} \mathrm{H}_{4}, 4-\mathrm{BrC}_{6} \mathrm{H}_{4}$

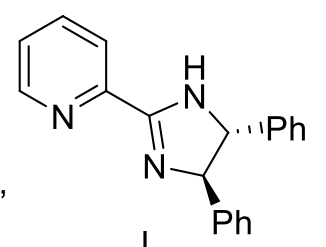

\section{Scheme 14}


Various $\alpha$-allylated 3-amino-2-oxindoles 43a were achieved by the Barbier-type allylation of isatin imines 31 with allylic comppounds 42a using metallic barium as the promoter (Scheme 14). ${ }^{44}$ In a similar study, Chen and Cai described the $\operatorname{In}(\mathrm{OTf})_{3}$-catalyzed allylation of ketimines derived from isatins $\mathbf{3 1}$ in the presence of an imidazolylpyridine ligand, $L$ (Scheme 14). ${ }^{45}$

The 2-oxindoles bearing chiral $\alpha$-tertiary amines at the 3-position $\mathbf{4 6}$ were prepared in good yields and with high enantioselectivities via a $\mathrm{Pd}(\mathrm{II}) /$ Pyrox-catalyzed addition of arylboronic acids $\mathbf{4 5}$ to 3-ketimine isatins 44 (Scheme 15). ${ }^{46}$ The absolute configuration of one of the products $\left(R^{2}=H\right)$ was determined to be $R$ and the absolute configuration of the $\mathrm{C}=\mathrm{N}$ bond of the 3-ketimine isatin was determined to be $E$ by $\mathrm{X}$-ray crystallographic analysis.

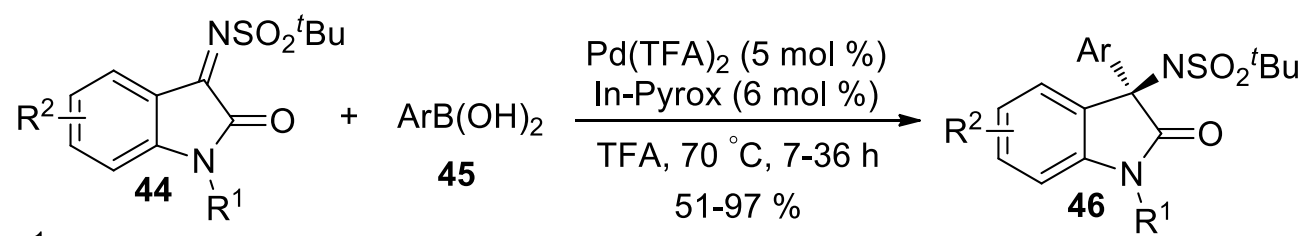

$\mathrm{R}^{1}=\mathrm{H}, 5-\mathrm{Me}, 5-\mathrm{MeO}, 5-\mathrm{F}, 5-\mathrm{Br}, 6-\mathrm{Cl}, 6-\mathrm{Br}, 7-\mathrm{F}, 7-\mathrm{Br}$

$\mathrm{R}^{2}=2,6-\mathrm{Cl}_{2} \mathrm{C}_{6} \mathrm{H}_{3} \mathrm{CH}_{2}$

$\mathrm{Ar}=4-\mathrm{MeC}_{6} \mathrm{H}_{4}, 4-t-\mathrm{BuC}_{6} \mathrm{H}_{4}, 4-\mathrm{MeOC}_{6} \mathrm{H}_{4}, 4-\mathrm{FC}_{6} \mathrm{H}_{4}$, 4- $\mathrm{ClC}_{6} \mathrm{H}_{4}, 4-\mathrm{BrC}_{6} \mathrm{H}_{4}, 3-\mathrm{MeC}_{6} \mathrm{H}_{4}, 3-\mathrm{MeOC}_{6} \mathrm{H}_{4}, 3-\mathrm{BrC}_{6} \mathrm{H}_{4}$

3,5- $-\mathrm{Me}_{2} \mathrm{C}_{6} \mathrm{H}_{3}$, thienyl, benzodioxolyl

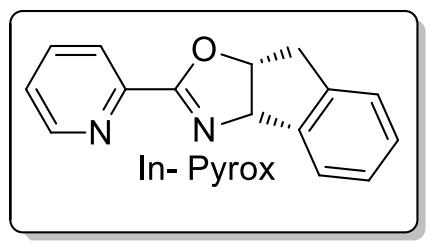

\section{Scheme 15}

A simple and efficient way for the synthesis of a series of chiral $\alpha$-trifluoromethylamines $\mathbf{4 9}$ with excellent yields and stereoselectivities was reported by $\mathrm{Li}$ and co-workers. The reaction was performed between $N$ 2,2,2-trifluoroethylisatin ketimines 47 and $\mathrm{MBH}$ type carbonates 48 using $\beta$-isocupreidine ( $\beta$-ICD) as catalyst. A possible mechanism of this reaction was proposed, as shown in scheme $16, \beta-I C D$ attacks the $\mathrm{MBH}$ carbonate 48 via an $S_{N} 2^{\prime}$ process (intermediate B). It behaves as a Lewis base chiral catalyst. This is followed by another $S_{N 2}$ '-type process, with the isatinketimine 47 acting as an active nucleophile (intermediate A) (Scheme 16). ${ }^{47}$

Elghamry and Al-Faiyz developed a new method for the synthesis of quinoline-4-carboxylic acids $\mathbf{5 1}$ using isatin $\mathbf{1}$ and enaminones $\mathbf{5 0}$ as a substitute for 1,3-dicarbonyl compounds in the Pfitzinger reaction (Scheme 17). ${ }^{48}$

Microwave assisted synthesis of 4-phenyl-1,3-thiazole derivatives 54 from the reaction of isatin 1, 2bromoethanones $\mathbf{5 2}$ and thiosemicarbazide $\mathbf{5 3}$ has been accomplished (Scheme 18). ${ }^{49}$ The synthesized compounds were tested for their antimicrobial activities. 
<smiles></smiles>

47<smiles>[R]C(=O)C(=C)C([R])OC(=O)O</smiles>

48

$\mathrm{R}^{1}=\mathrm{H}, 4-\mathrm{Cl}, 4-\mathrm{Br}, 5-\mathrm{Me}, 5-\mathrm{Br}$

$\mathrm{R}^{2}=\mathrm{Me}, \mathrm{Et}, \mathrm{OMe}, \mathrm{OEt}, \mathrm{O}^{t} \mathrm{Bu}$

$\mathrm{R}^{3}=\mathrm{C}_{6} \mathrm{H}_{5}, 2-\mathrm{ClC}_{6} \mathrm{H}_{4}, 2-\mathrm{MeC}_{6} \mathrm{H}_{4}, 2-\mathrm{MeOC}_{6} \mathrm{H}_{4}$, 3- $\mathrm{ClC}_{6} \mathrm{H}_{4}, 3-\mathrm{MeC}_{6} \mathrm{H}_{4}, 3-\mathrm{MeOC}_{6} \mathrm{H}_{4}, 4-\mathrm{ClC}_{6} \mathrm{H}_{4}$, $4-\mathrm{FC}_{6} \mathrm{H}_{4}, 4-\mathrm{BrC}_{6} \mathrm{H}_{4}, 4-\mathrm{MeC}_{6} \mathrm{H}_{4}, 4-\mathrm{MeOC}_{6} \mathrm{H}_{4}$, thienyl, $\alpha$-naphthyl, $\beta$-naphthyl<smiles></smiles>

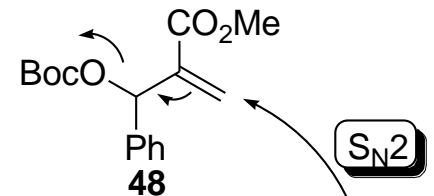

${ }^{t} \mathrm{BuOH}$<smiles>CC(C)(C)CCCCCCC(C)(C)C(F)(F)F</smiles>

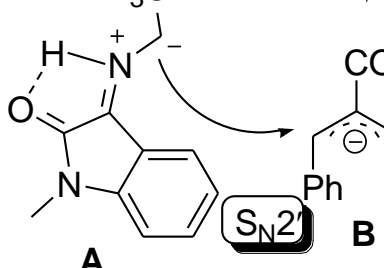

A<smiles>[Y17]CC(C)(C[18O])CC(=O)O</smiles>

$\mathrm{Ph}$, .<smiles>Oc1cc2nccc(C3OC4CCC3CC4)c2cc1O</smiles>

49<smiles>[R]C(=O)C(=C)C([R])C(N=CC(=O)O)C(F)(F)F</smiles>

\section{Scheme 16}

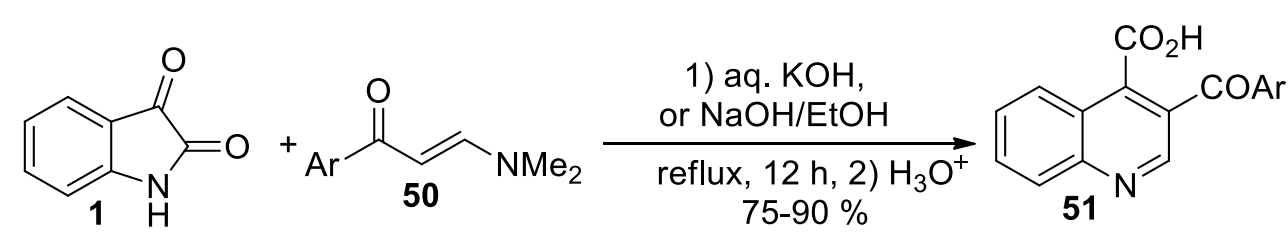

$\mathrm{Ar}=\mathrm{C}_{6} \mathrm{H}_{5}, 4-\mathrm{MeC}_{6} \mathrm{H}_{4}, 4-\mathrm{MeOC}_{6} \mathrm{H}_{4}, 4-\mathrm{ClC}_{6} \mathrm{H}_{4}, 4-\mathrm{BrC}_{6} \mathrm{H}_{4}$

\section{Scheme 17}

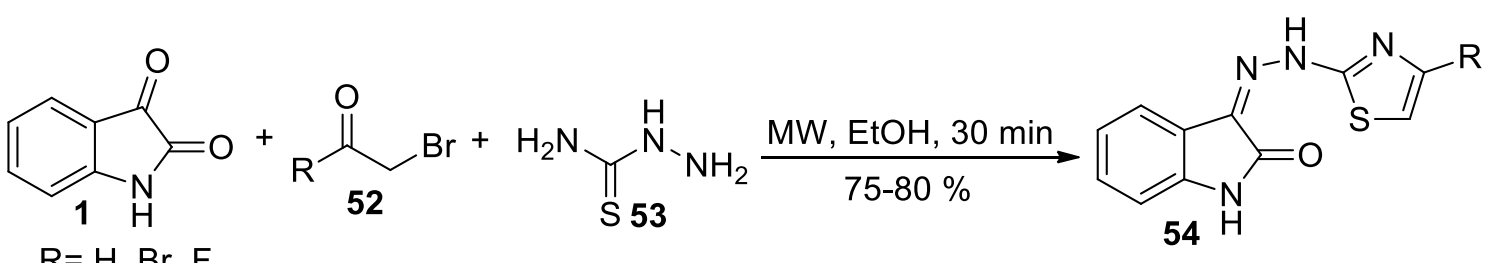

\section{Scheme 18}


2,4-Dinitrophenol (DNP) facilitated the three component reaction of isatins 1, cyclic-amines 55 and alkynes 8 to prepare the mono-functionalized $\alpha$-alkynyl-3-amino-2-oxindole derivatives 56 (Scheme 19). ${ }^{50}$

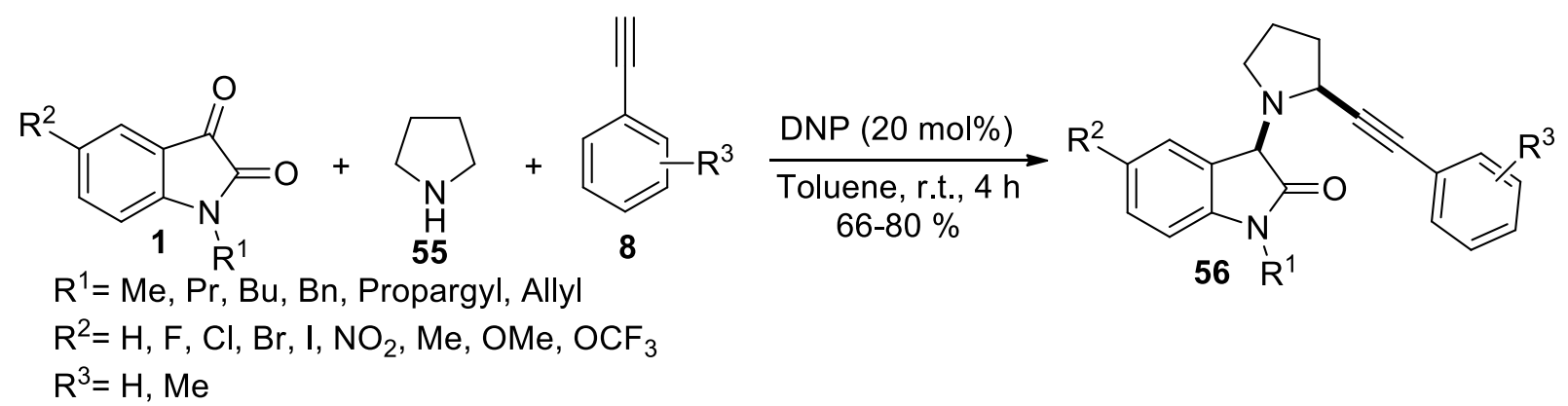

\section{Scheme 19}

The new indole derivative $5,5^{\prime \prime}$-difluoro- $1 H, 1^{\prime \prime} H$-[3, $3^{\prime}: 3^{\prime}, 3^{\prime \prime}$-terindol]-2' $\left(1^{\prime} H\right)$-one 58 has been synthesized from the reaction of isatin 1 and 2 eq. 5-fluoroindole 57 in the presence of sulfamic acid as an efficient organocatalyst (Scheme 20). ${ }^{51}$ Crystal structure of the product was determined by X-ray structure analysis. In other studies, the reactions of various isatin derivatives $\mathbf{1}$ and indoles $\mathbf{5 7}$ were also investigated in the presence of nano $\mathrm{SiO}_{2}{ }^{52}$ and $\mathrm{Fe}_{3} \mathrm{O}_{4} @ \mathrm{SiO}_{2} @ \mathrm{SO}_{3} \mathrm{H}^{53}$ as catalysts.<smiles>O=C1Nc2ccccc2C1=O</smiles>

1<smiles></smiles>

57
$\mathrm{NH}_{2} \mathrm{SO}_{3} \mathrm{H}(20 \mathrm{~mol} \%)$

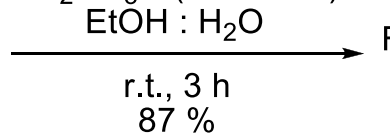

$87 \%$

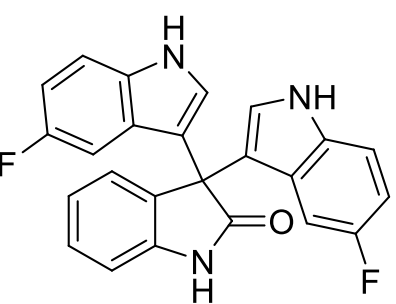

58

\section{Scheme 20}

A tunable copper-catalyzed azide-alkyne cycloaddition (CuAAC)-initiated multicomponent reaction strategy for the construction of 3-functionalized indolin-2-ones have been reported. In this regard, the reaction of isatins $\mathbf{1}$, tosyl azides $\mathbf{5 9}$, and terminal alkynes $\mathbf{8}$ the presence of Cul and Et ${ }_{4} \mathrm{NI}$ was developed. This tandem process can be manipulated to proceed in three-component and four-component fashion respectively, yielding a range of (Z)-3-alkenyloxindole 60 or 3-substituted 3-hydroxyoxindole 61 compounds (Scheme 21). 54

Meshram and co-workers reported a one-pot four component protocol for the synthesis of a novel class of functionalized (Z)-5-(3-hydroxy-2-oxoindolin-3-yl)-2-iminothiazolidin-4-ones 63 by the reaction of substituted isatins 1, amines 55, phenylisothiocyanate 62 and ethyl bromoacetate 35 in the presence of DABCO as catalyst in aqueous medium (Scheme 22). ${ }^{55}$ The 5-halo isatins reacted under standard condition and resulted in moderate yields of products while other 5-substituted isatins reacted smoothly to furnish the desired products in high yields. As like monosubstituted isatins, disubstituted isatins reacted in the same way and afforded comparatively less yield of desired products under standard reaction conditions. 


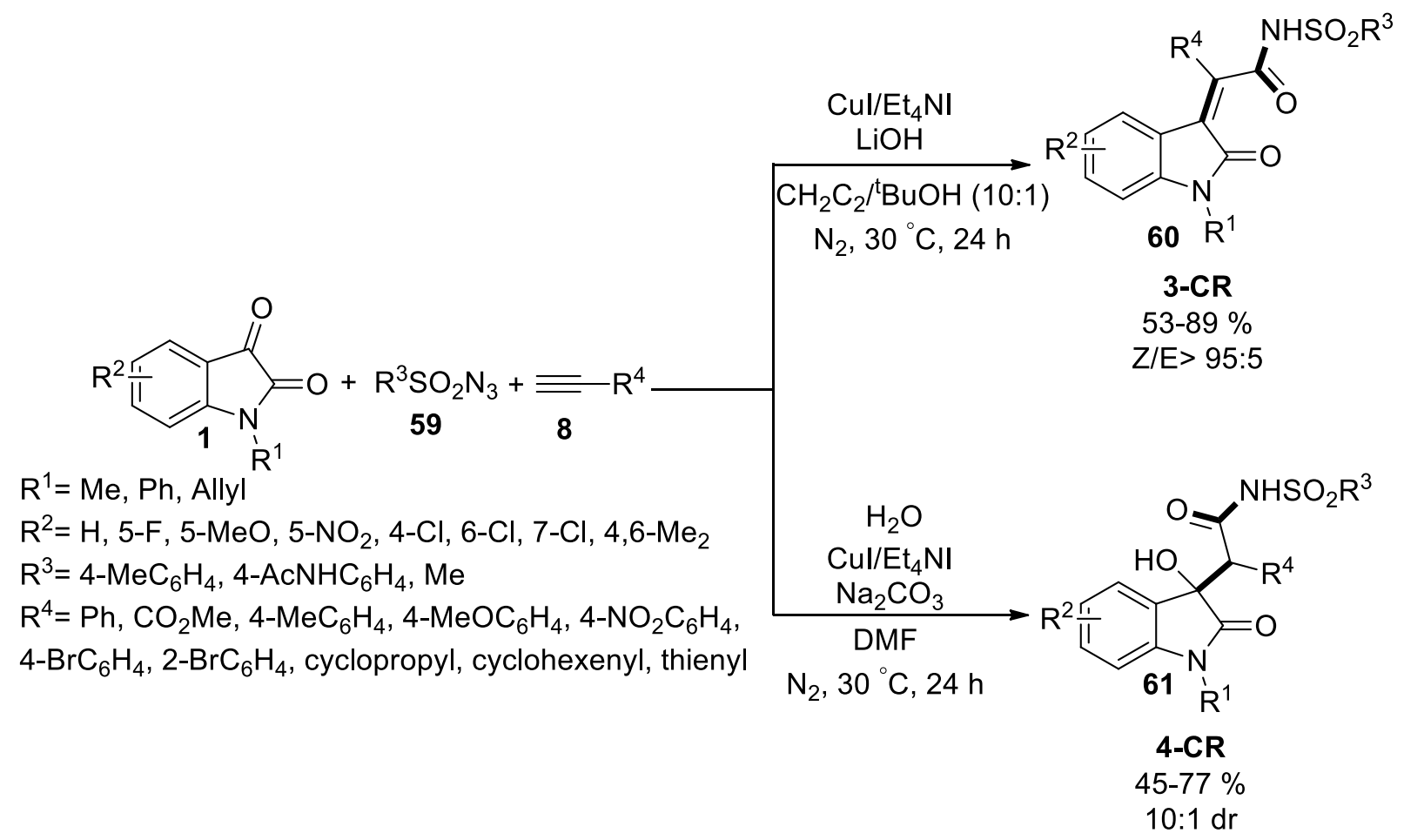

\section{Scheme 21}

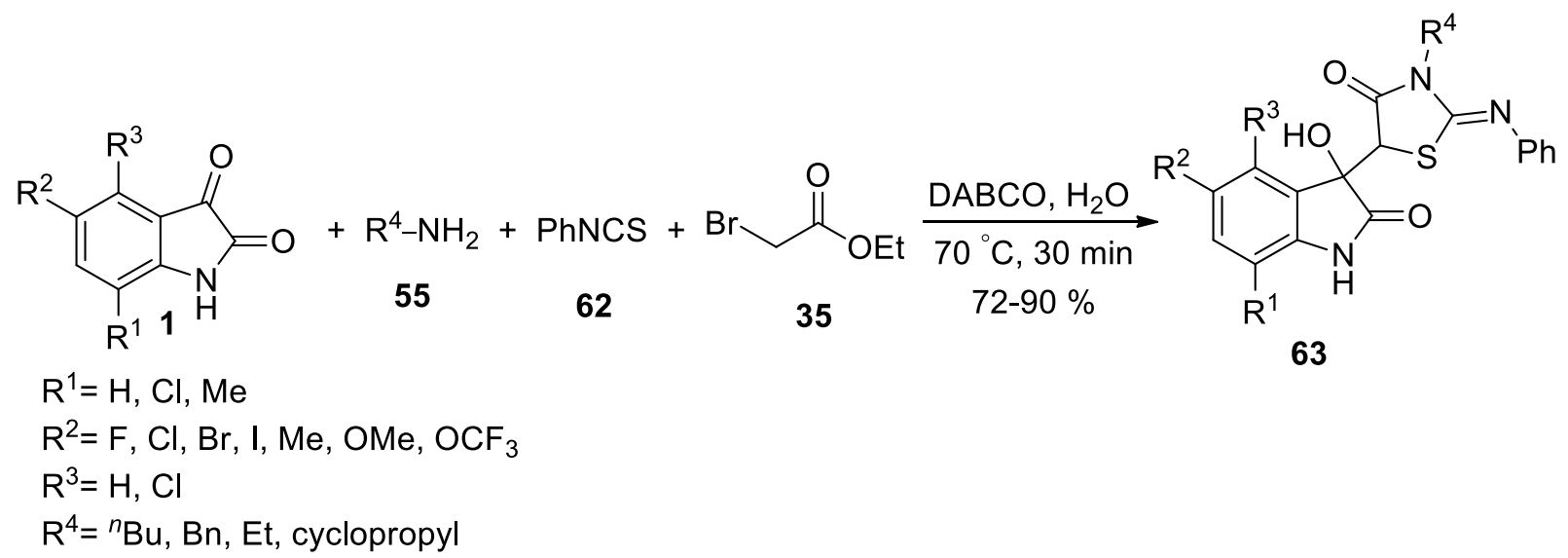

\section{Scheme 22}

\section{Synthesis of Isatin-based Spiro-fused Heterocyclic Frameworks}

The heterocyclic spirooxindole ring system is a widely distributed structural framework in a number of pharmaceuticals and natural products, ${ }^{56}$ including cytostatic alkaloids such as spirotryprostatins A, B, and strychnophylline. ${ }^{57}$ The unique structural array and the highly pronounced pharmacological activity displayed by the class of spirooxindole compounds have made them attractive synthetic targets (Figure 1). ${ }^{58-60}$ 
<smiles>Cn1c(C#N)ccc1-c1ccc2c(c1)C1(CCCCC1)C(=O)N2</smiles>

Progesteron receptor agonist<smiles>CCC1(c2ccc(Cl)cc2)CC(=O)CC[C@]12C(=O)Nc1cc(Cl)ccc12</smiles>

MDM2-p53 interaction<smiles>Cc1cc(F)cc(N2C[C@]3(CC2=O)C(=O)N(CC(=O)O)c2ccc(Cl)cc23)c1</smiles>

CR TH2 receptor antagonist<smiles>[M]C1CC2c3cc(F)c(Cl)cc3NC2[C@@]2(N1)C(=O)Nc1ccc(Cl)cc12</smiles>

Antimalarial activity

\section{Figure 1}

\subsection{Synthesis involving two-component reactions of isatins}

3.1.1. Three-membered heterocycles. Hajra et al. carried out the asymmetric synthesis of spiroaziridine oxindoles 67a, 67b via the aza Corey-Chaykovsky reaction of isatin-derived tert-butanesulfinyl ketimines 64 with in situ generated sulfur ylide from trimethylsulfonium iodide $\mathbf{6 5}$ (or the reaction of benzyl sulfur ylides generated from $S$-benzyl tetrahydrothiophenium bromide $\mathbf{6 6}$ with chiral tertbutanesulfinyl ketimines 64 ) and $\mathrm{NaH}$ (Scheme 23). ${ }^{61}$

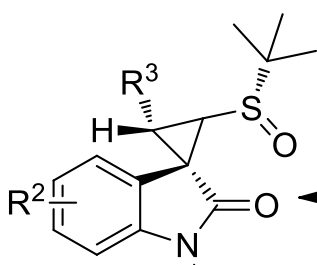
$67 \mathrm{~b} \mathrm{R}^{1}$

$\mathrm{R}^{1}=\mathrm{Me}$ $\mathrm{R}^{2}=\mathrm{H}, 5-\mathrm{F}, 5-\mathrm{Br}$,

5-Cl, 5-MeO, 5,7- $\mathrm{Me}_{2}$ $\mathrm{R}^{3}=\mathrm{H}, 4-\mathrm{ClC}_{6} \mathrm{H}_{4}, 4-\mathrm{NO}_{2} \mathrm{C}_{6} \mathrm{H}_{4}$<smiles>C[R17]1ccc2c(c1)/C(=N/[S@](=O)C(C)(C)C)C(=O)N2</smiles>

$64 R^{1}$ $30-50 \mathrm{~min}$ $66-78 \%$

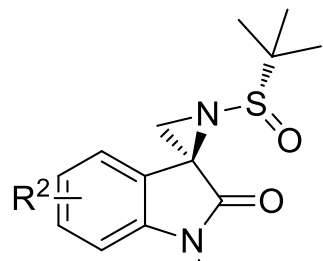

67 a $\stackrel{R}{1}^{1}$ $61-77 \%$ $\mathrm{R}^{1}=\mathrm{Me}, \mathrm{Bn}$ $\mathrm{R}^{2}=\mathrm{H}, 5-\mathrm{F}, 7-\mathrm{F}, 5-\mathrm{Br}$, 5-Cl, 5-MeO, 5,7- $\mathrm{Me}_{2}$

\section{Scheme 23}

An efficient chemoselective access to rare spiro-epoxyoxindoles 70 has been developed through the addition of the carbenoidic chloromethyllithium $\mathbf{6 9}$ to various $N$-functionalized isatins $\mathbf{1}$ followed by the ring closure (Scheme 24). ${ }^{62}$ 


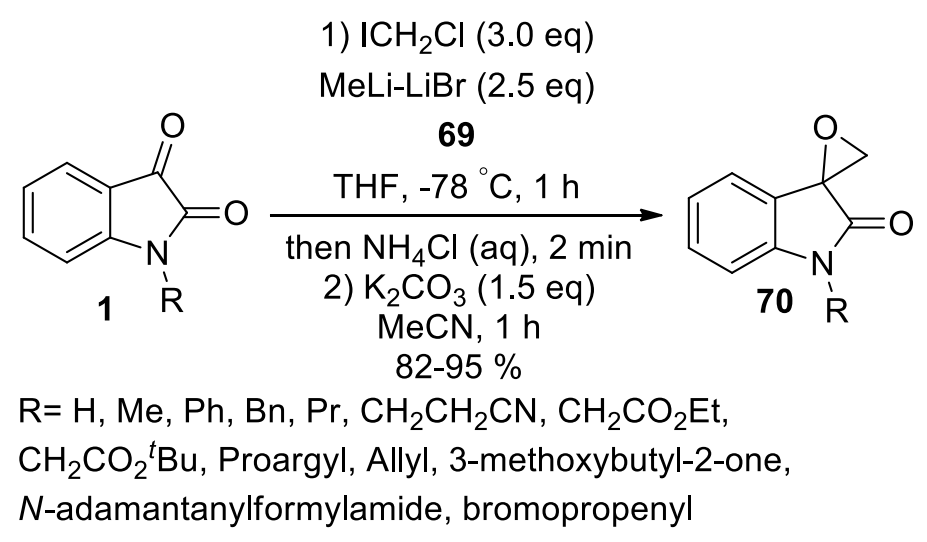

\section{Scheme 24}

3.1.2. Five-membered heterocycles. Wang et al. developed an $\alpha$-regioselective asymmetric [3 +2$]$ annulation reaction of isatins $\mathbf{7 1}$ and 1-azadienes $\mathbf{7 2}$ for the synthesis of bulky 1,2-benzoisothiazole 1,1-dioxide motifs $\mathbf{7 3}$ (Scheme 25). ${ }^{63}$

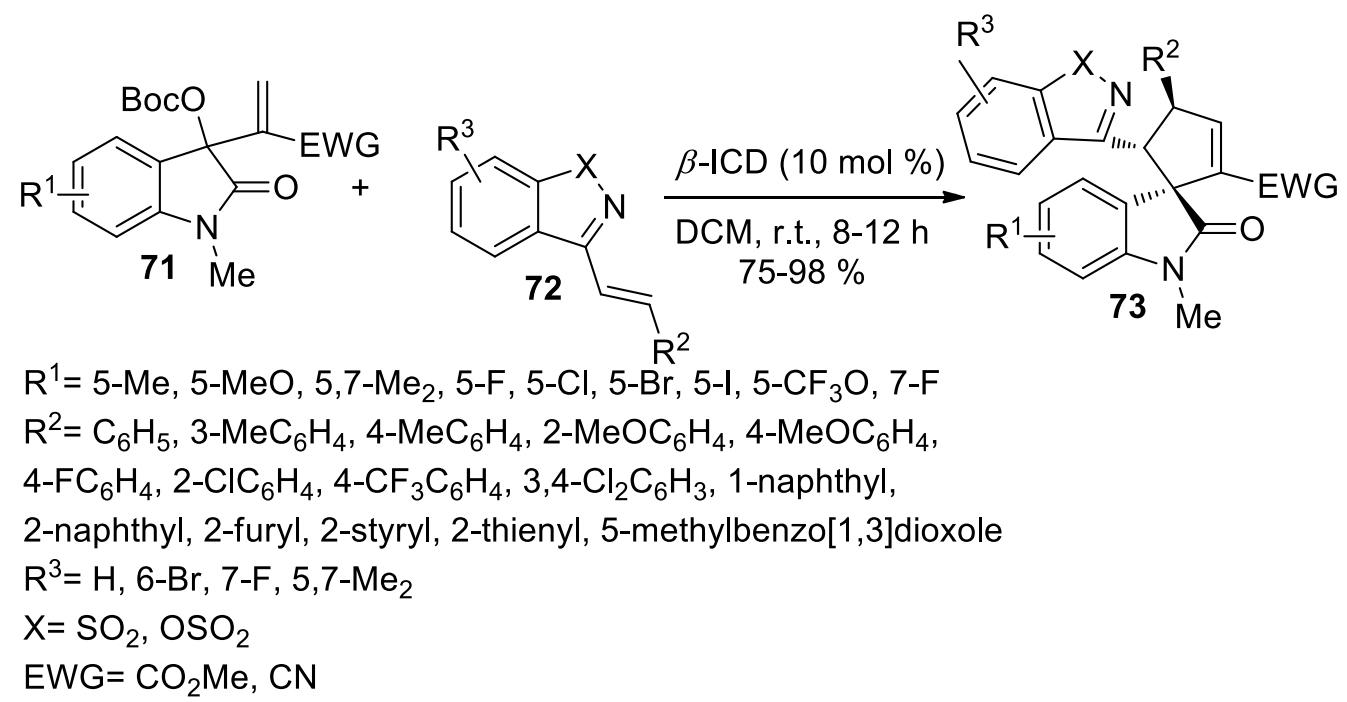

\section{Scheme 25}

Zhao and Du developed an efficient cascade Michael/Michael reaction catalyzed by a bifunctional tertiary amine-squaramide catalyst for the asymmetric synthesis of five-membered spirooxindoles containing five contiguous stereocenters $\mathbf{7 6}$ from the reaction of isatin derived enoates $\mathbf{7 4}$ and $\alpha$-alkylidene succinimides $\mathbf{7 5}$. The products were obtained with excellent diastereoselectivities and enantioselectivities (Scheme 26). ${ }^{64}$ 
$\mathrm{R}^{1}$<smiles>[R]OC(=O)C1C(=[O+])Nc2cc[R1]cc21</smiles>

74 Boc

$\mathrm{R}^{1}=\mathrm{H}, 5-\mathrm{F}, 5-\mathrm{Cl}, 5-\mathrm{Br}, 5-\mathrm{I}$,

$5-\mathrm{Me}, 5-\mathrm{MeO}, 5-\mathrm{NO}_{2}, 6-\mathrm{Cl}$

$\mathrm{R}^{2}=\mathrm{Et},{ }^{t} \mathrm{Bu}$

$\mathrm{R}^{3}=\mathrm{C}_{6} \mathrm{H}_{5}, 4-\mathrm{FC}_{6} \mathrm{H}_{4}, 4-\mathrm{ClC}_{6} \mathrm{H}_{4}$,

$4-\mathrm{BrC}_{6} \mathrm{H}_{4}, 4-\mathrm{MeC}_{6} \mathrm{H}_{4}, 2-\mathrm{BrC}_{6} \mathrm{H}_{4}$,

2- $\mathrm{MeOC}_{6} \mathrm{H}_{4}, \mathrm{CH}_{2} \mathrm{CH}_{2} \mathrm{C}_{6} \mathrm{H}_{4}$,

naphthyl, thienyl<smiles>[R]C=C1CC(=O)N(C(=O)OCc2ccccc2)C1=O</smiles>

75 $\underset{\text { cat }(5 \mathrm{~mol} \%)}{\stackrel{\text { THF, r.t., } 20-30 \mathrm{~h}}{63-93 \%}}$
列

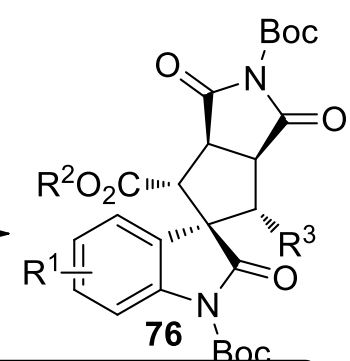

76

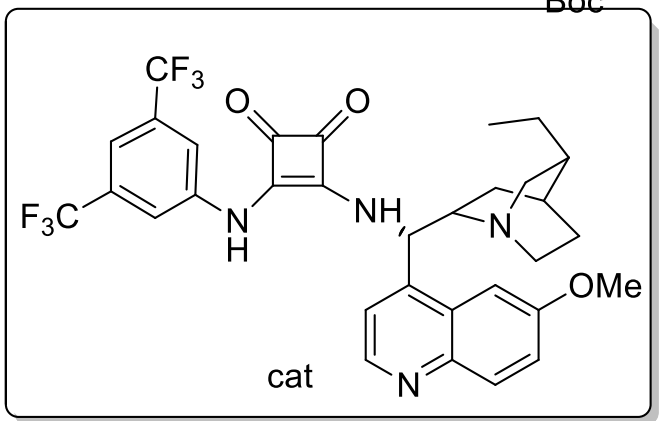

\section{Scheme 26}

The functionalized 3,3'-pyrrolidinyldispirooxindole derivatives $\mathbf{7 8}$ with three stereogenic centers, including two contiguous spiro-stereocenters were achieved from the stereoselective organocatalytic Mannich/Bocdeprotection/aza-Michael sequence reaction of isatin imines $\mathbf{3 1}$ and the 3-substituted oxindoles $\mathbf{7 7}$ employing the commercially available (DHQD) 2 PHAL as the catalyst (Scheme 27$).{ }^{65}$

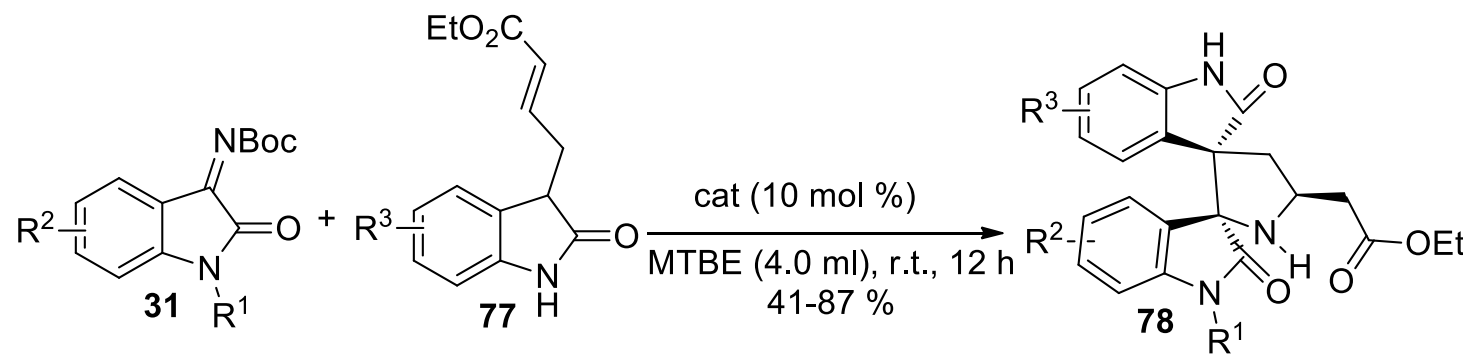

$\mathrm{R}^{1}=\mathrm{Me}, \mathrm{Et}, \mathrm{CH}_{2} \mathrm{C}_{6} \mathrm{H}_{4}, 4-\mathrm{BrC}_{6} \mathrm{H}_{4} \mathrm{CH}_{2}$ $\mathrm{R}^{2}=\mathrm{H}, 5-\mathrm{F}, 5-\mathrm{Cl}, 5-\mathrm{Br}, 5-\mathrm{Me}, 5-\mathrm{MeO}$, $5-\mathrm{CF}_{3} \mathrm{O}, 5-\mathrm{NO}_{2}, 7-\mathrm{F}, 7-\mathrm{Cl}$ $\mathrm{R}^{3}=\mathrm{H}, 5-\mathrm{Cl}$

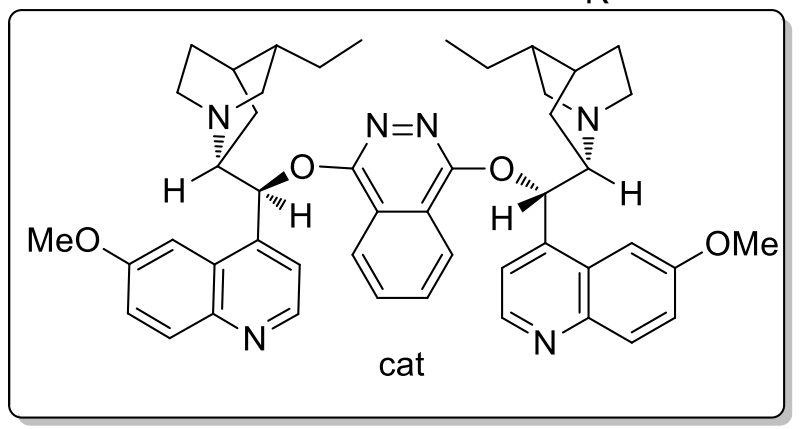

\section{Scheme 27}

The synthesis of 3,2'-dihydropyrrolyl spirooxindoles $\mathbf{8 0}$ with excellent enantioselectivities (up to >99\%) was accomplished by asymmetric [3 +2 ] annulation of isatin imines $\mathbf{3 1}$ with zwitterions generated from allenyl esters as well as allenyl ketones 79 catalyzed by L-isoleucine derived bifunctional $N$-acylaminophosphine (Scheme 28). ${ }^{66}$ 


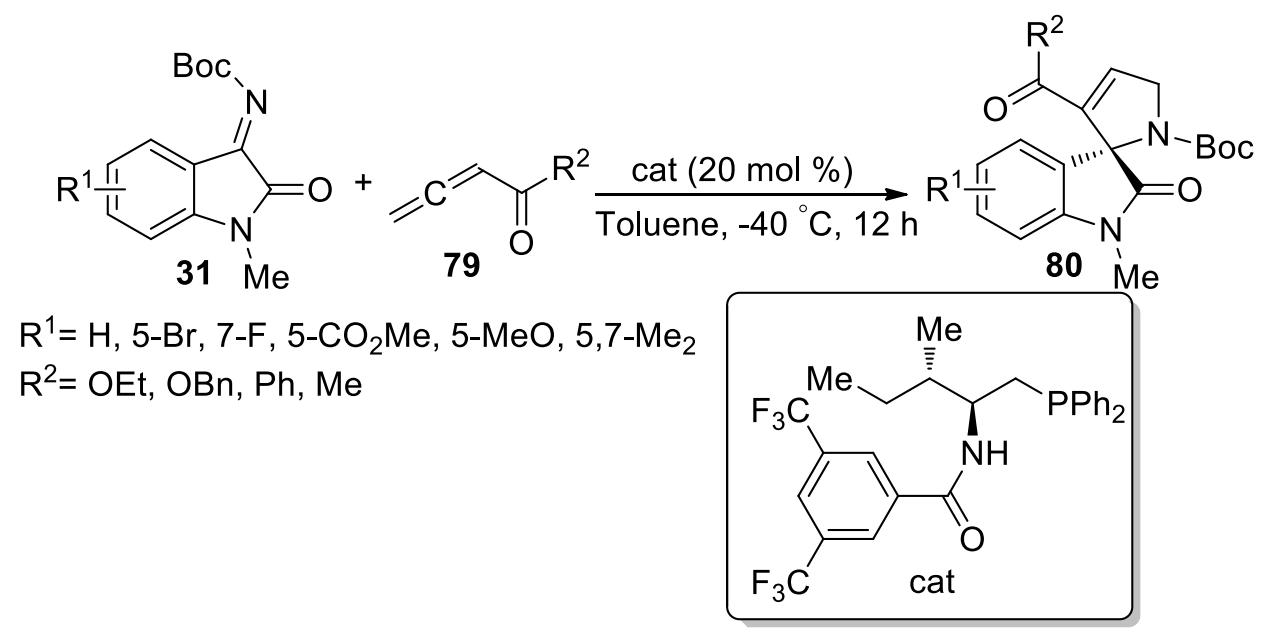

\section{Scheme 28}

The enantioenriched spirooxindole based 4-thiazolidinones 82 were accessed through the catalytic asymmetric [3 + 2] annulation of isatin ketimines 31 with the 1,4-dithiane-2,5-diol 81 using a bifunctional catalyst followed by simple oxidation with high enantioselectivity (up to $98 \%$ ee) (Scheme 29). ${ }^{67}$

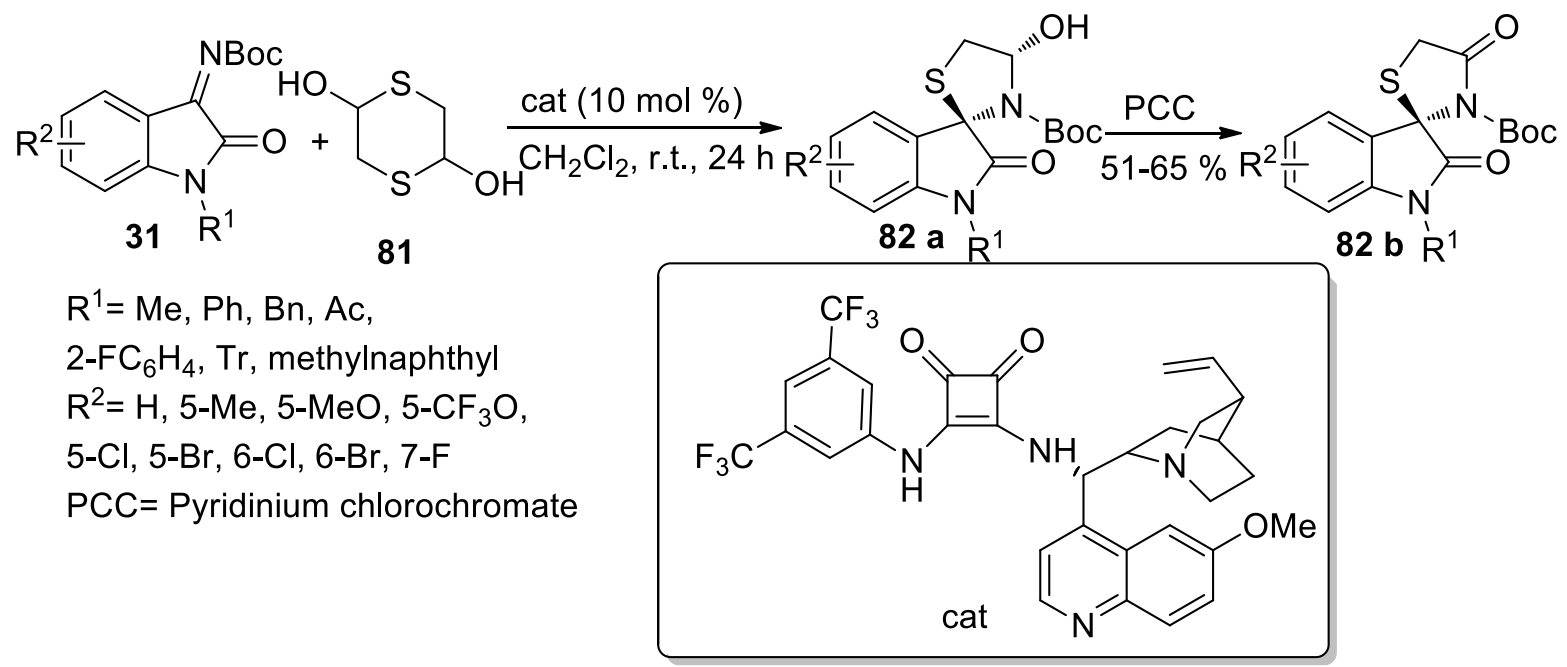

\section{Scheme 29}

3.1.3. Six-membered heterocycles. The hetero-Diels-Alder (hDA) reaction of isatins $\mathbf{1}$ with enones $\mathbf{8 3}$ that was catalyzed by an amine-based catalyst system composed of three molecules (an amine, an acid and a thiourea) was accomplished for synthesis of the functionalized spirooxindole tetrahydropyran derivatives $\mathbf{8 4}$ according to intermediates A-C (Scheme 30). ${ }^{68,69}$ 


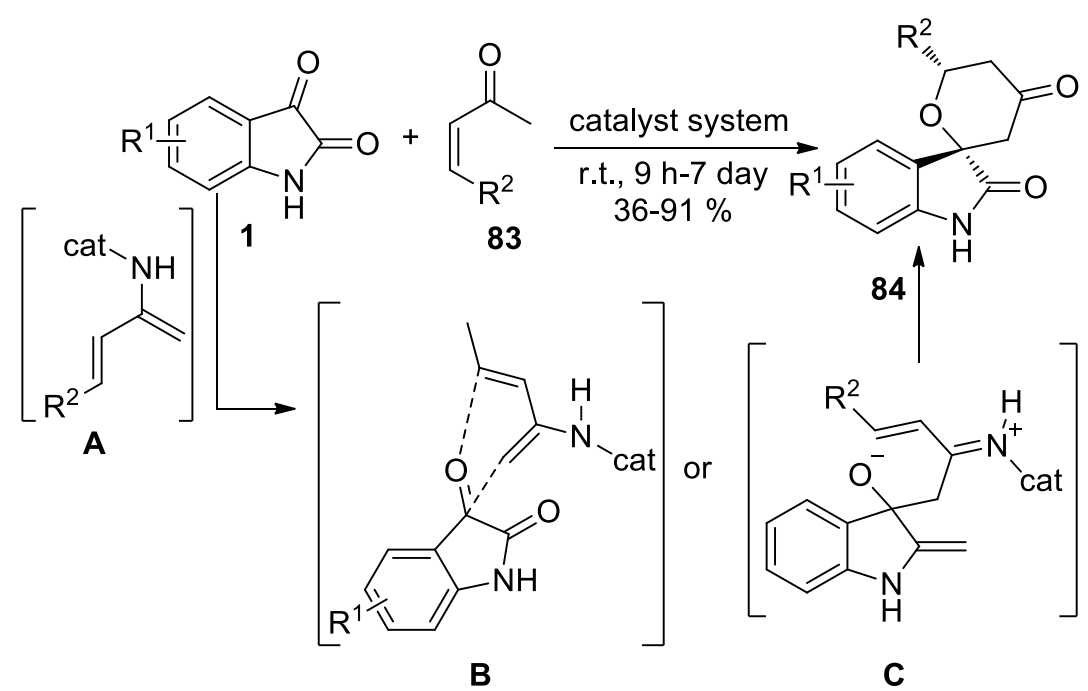

$\mathrm{R}^{1}=4-\mathrm{Cl}, 4-\mathrm{Br}, 5-\mathrm{Br}, 5-\mathrm{Me}, 6-\mathrm{Cl}$<smiles>[R]=CC[R]c1ccccc1</smiles><smiles>C=CC1CC2CCC1C2N(N)c1ccnc2ccccc12</smiles>

\section{Scheme 30}

The enantioselective [ $4+2$ ] assemble of spirolactones 85 through a chiral $\mathbf{N}$-heterocyclic carbene (NHC)catalyzed remote $\gamma$-carbon addition of enals $\mathbf{8 3}$ with isatins $\mathbf{1}$ was reported by Zhou and co-workers (Scheme 31). ${ }^{70}$ Yao and co-workers studied this reaction using the same catalyst and base. ${ }^{71}$

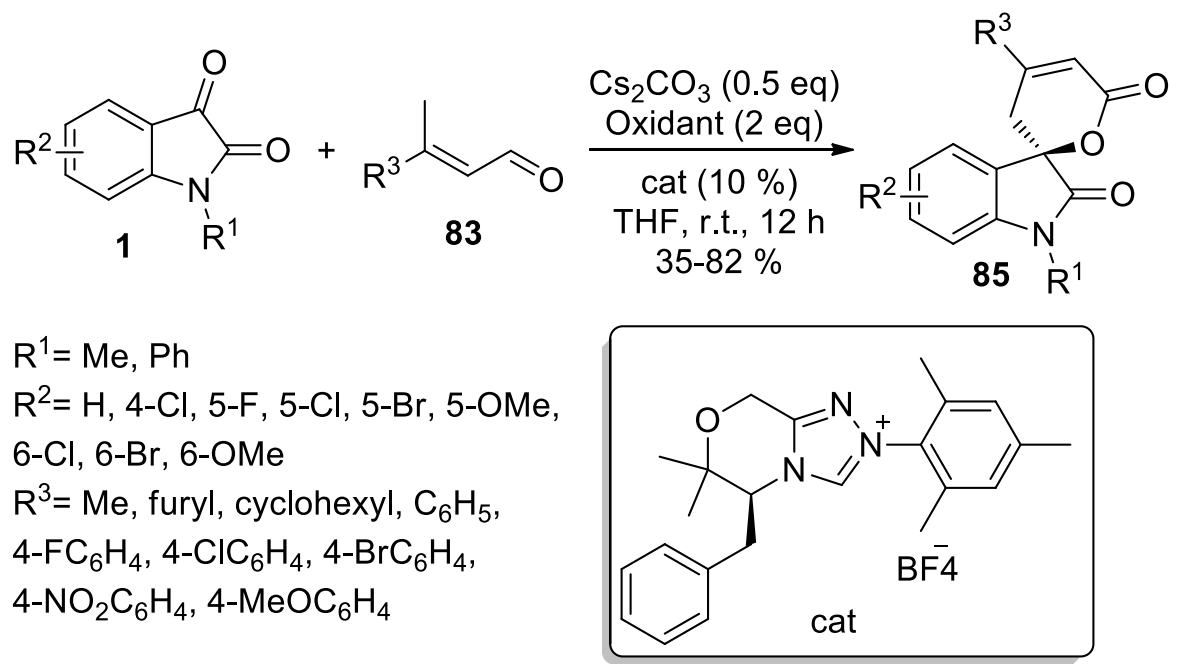

\section{Scheme 31}

The vinylogous aldol-cyclization cascade reaction of 3-alkylidene oxindoles 86 to isatins $\mathbf{1}$ has been achieved by using bifunctional organocatalysts in $\mathrm{CH}_{2} \mathrm{Cl}_{2}$ at room temperature. According to the proposed 
mechanism, first oxindole $\mathbf{8 7}$ was deprotonated by catalyst and generated s-cis enolate $\mathbf{A}$, which then was added through the Si face to isatin $\mathbf{1}$ to give alkoxide intermediate $\mathbf{B}$. After cyclization and protonation of the intermediate $\mathbf{B}$, the desired product $\mathbf{8 7}$ was delivered and catalyst was regenerated (Scheme 32). ${ }^{72}$

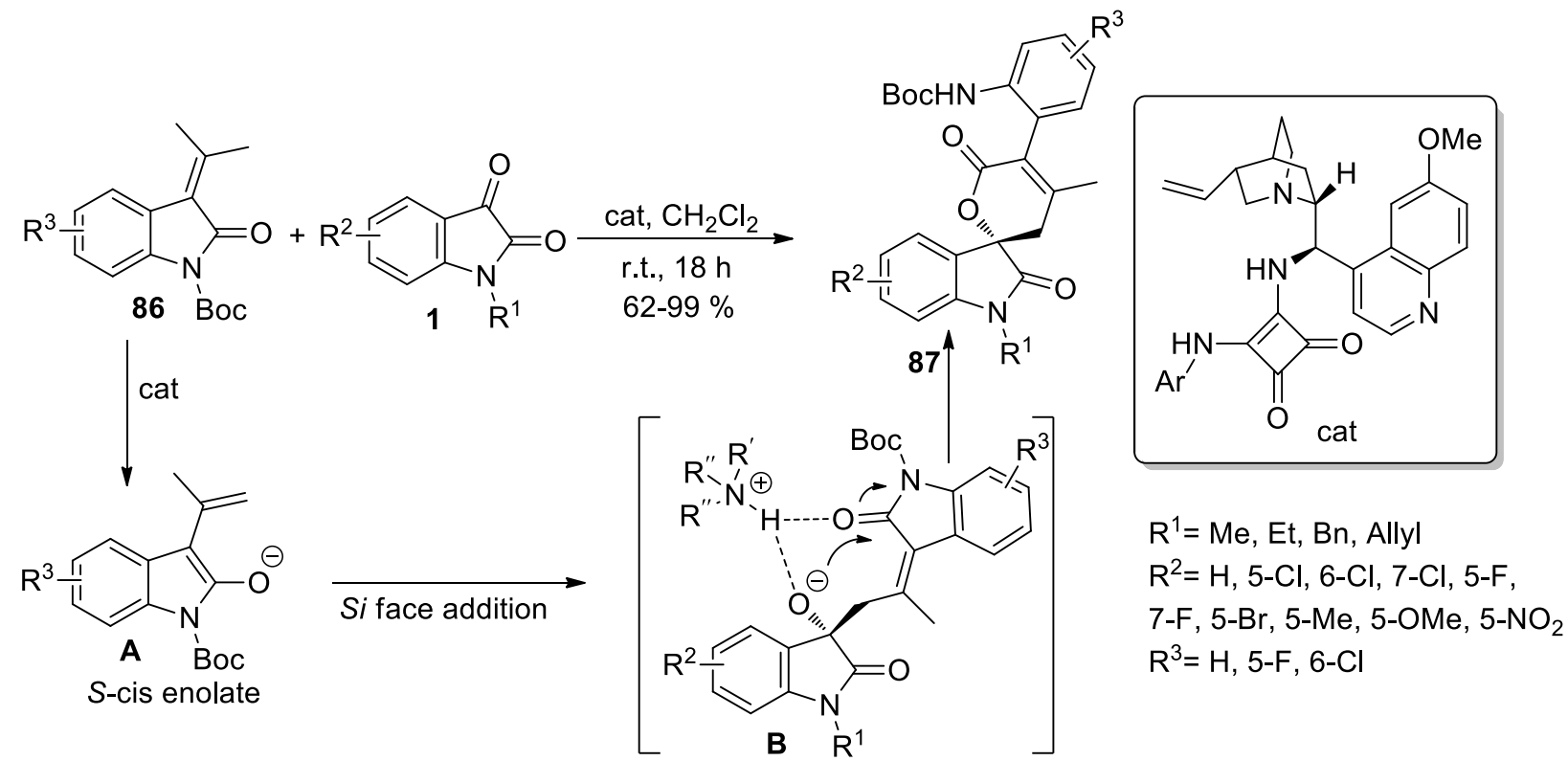

\section{Scheme 32}

The biologically active dihydropyrones $\mathbf{8 9}$ with a high level of enantioselectivities were synthesized from the hetero-Diels-Alder reaction of isatins 1 and glyoxal $\mathbf{8 8}$ in the presence of chiral copper catalyst (Scheme $33) .^{73}$

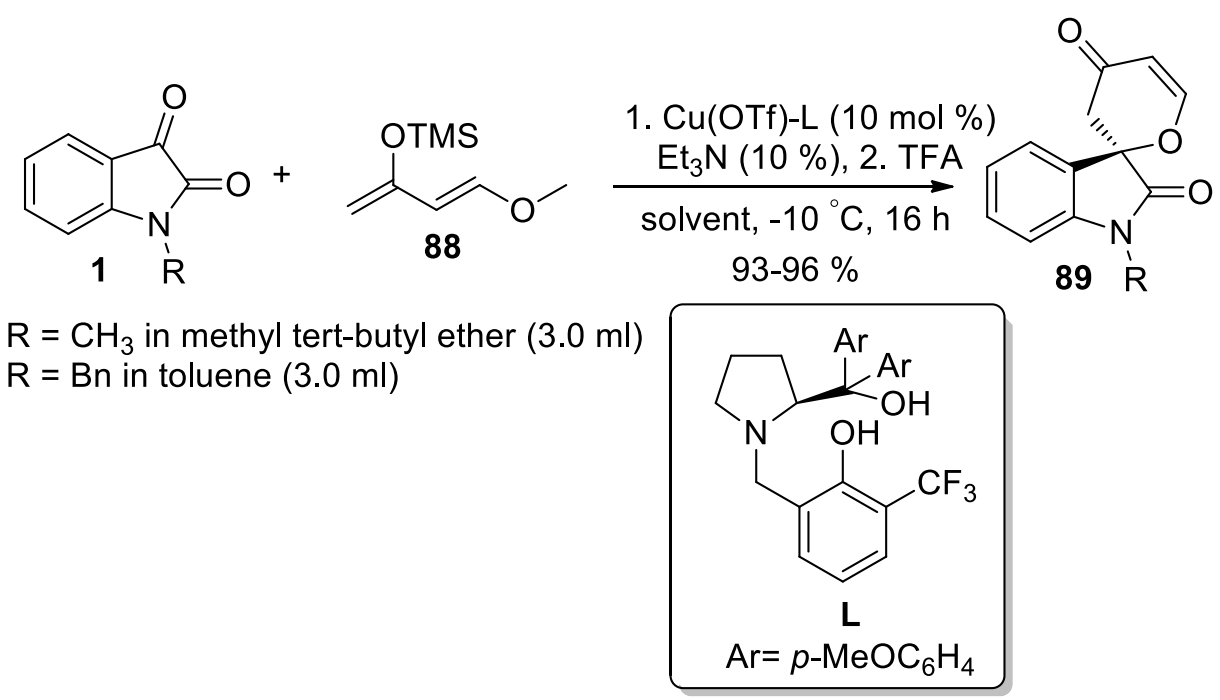

\section{Scheme 33}

The synthesis of 1 - $H$-spiro[isoindoline-1,2' -quinazoline]-3,4'(3'H)-diones 91 has been expediently accomplished by a reaction of isatins 1 and anthranilamide $\mathbf{9 0}$ in the presence of sulfamic acid as an efficient 
catalyst (Scheme 34). ${ }^{74}$ The products were found to be fluorescent with absorption in UV region (302, $362 \mathrm{~nm}$ ) and emission in visible region (413-436 nm) with Stokes shift of 44-72 nm.<smiles>O=c1[nH]c2cc[R]ccc=2c1=[OH+]</smiles>
1

$\mathrm{R}=5-\mathrm{F}, 5-\mathrm{Cl}, 5-\mathrm{Br}, 5-\mathrm{Me}, 5-\mathrm{MeO}, 5,7-\mathrm{Me}_{2}$<smiles>NC(=O)c1ccccc1N</smiles>

90 $76-92 \%$

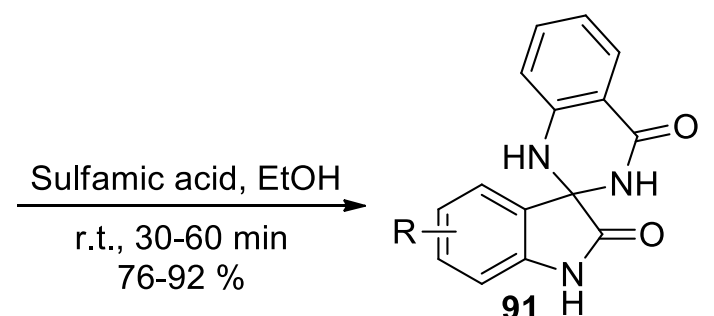

$91 \mathrm{H}$

\section{Scheme 34}

Kumarswamyreddy and Kesavan used the bifunctional squaramide organocatalyst derived from L-proline in the reaction between isatylidine $\beta, \gamma$-unsaturated $\alpha$-ketoesters $\mathbf{9 2}$ and pyrazolones $\mathbf{4 0}$ for the synthesis of dihydrospiro[indoline-3,4'-pyrano[2,3-c]pyrazole] derivatives 93 (Scheme 35). ${ }^{75}$

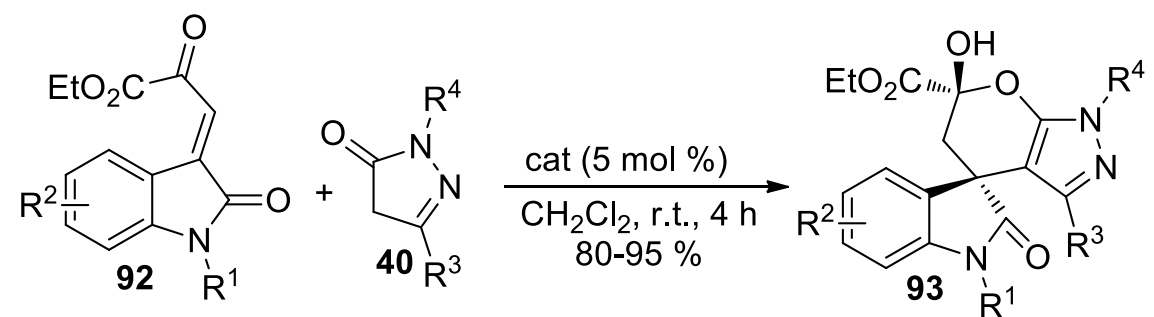

$$
\begin{aligned}
& \mathrm{R}^{1}=\mathrm{H}, \mathrm{Me}, \mathrm{Bn}, \text { Allyl, propargyl } \\
& \mathrm{R}^{2}=\mathrm{H}, 5-\mathrm{F}, 5-\mathrm{Cl}, 5-\mathrm{Br}, 5-\mathrm{I}, \\
& 5-\mathrm{MeO}, 5-\mathrm{CF}_{3} \mathrm{O}, 5,7-\mathrm{Me}_{2} \\
& \mathrm{R}^{3}=\mathrm{Me}, \mathrm{Ph}, \mathrm{CF}_{3}, 4-\mathrm{MeOC}_{6} \mathrm{H}_{4} \\
& \mathrm{R}^{4}=\mathrm{H}, \mathrm{Ph}, 2-\mathrm{FC}_{6} \mathrm{H}_{4}
\end{aligned}
$$

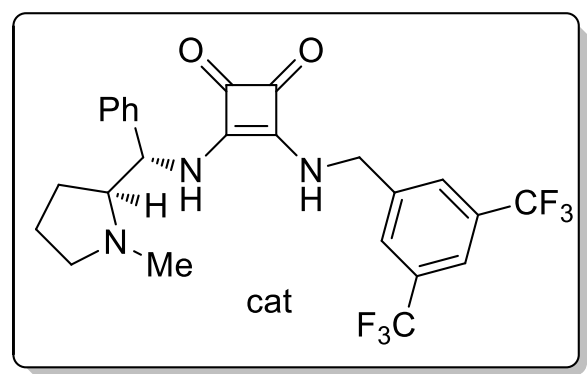

\section{Scheme 35}

An enantioselective Michael-Michael cascade reaction for the synthesis of chiral spirotetrahydrothiopyrans 95 was studied by Wang et al. In this reaction, highly functionalized scaffolds were assembled via the reaction of chiral spiro-tetrahydrothiopyranoxindoles $\mathbf{9 4}$ with trans-enones $\mathbf{8 3}$ using the organocatalyst in excellent diastereo- and enantio-selectivities (>30:1 dr, $\geq 99 \%$ ee) with the creation of four consecutive stereogenic centers. The novel spiro-oxindole scaffolds were validated as a new class of p53-MDM2 proteinprotein interaction inhibitors with good antitumor activity (Scheme 36). ${ }^{76}$ 


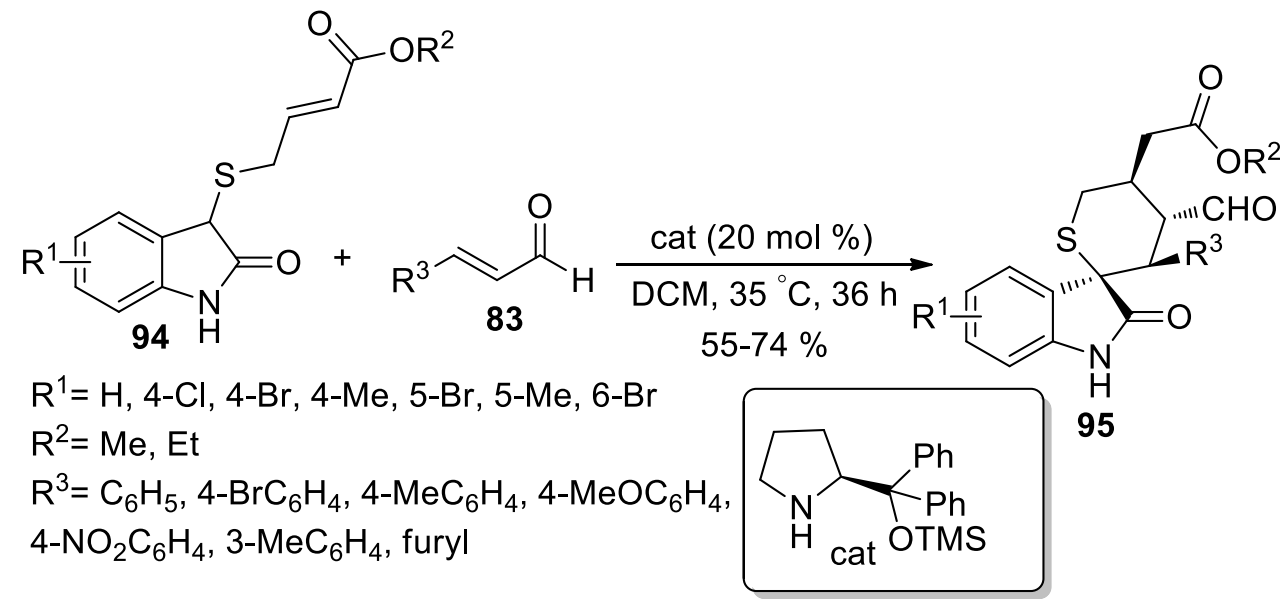

\section{Scheme 36}

Kumar et al. reported the synthesis of 1,3-dihydro-3-ureidoformimido-2H-indol-2-ones 97 and spiro[3Hindole-3, $2^{\prime}\left(1^{\prime} H\right)-(1,3,5)$ triazine]-2,4', $6^{\prime}\left(1 H, 3^{\prime} H, 5^{\prime} H\right)$-triones 98 from the reaction of isatins 1 and biuret 96 (Scheme 37). ${ }^{77}$ The reactions were carried out in two different methods; method A under slightly acidic conditions and method $B$ in the presence of glacial acetic acid as reaction medium. It was observed that under both conditions compound $\mathbf{9 7}$ was obtained as the main product, however method B also resulted in the formation of compound 98 as a minor product.

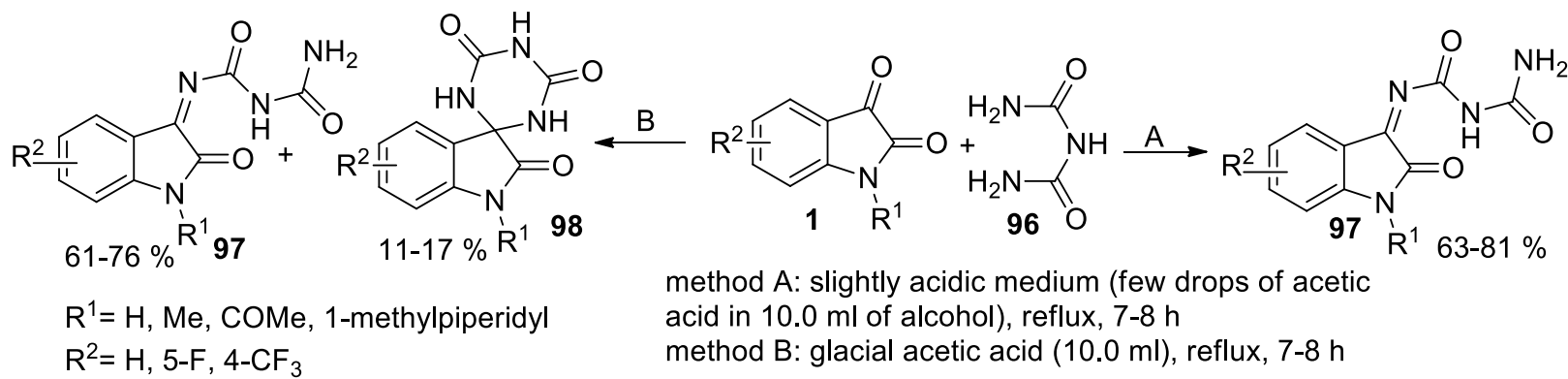

\section{Scheme 37}

3.1.4. Seven- membered heterocycles. The quaternary aza-spirocycloheptane oxindole scaffolds 100 have been synthesized via the [4+3] cycloaddition reaction of $\mathrm{MBH}$ carbonates derived from isatin 71 and $\mathrm{N}$-(ochloromethyl)aryl amides 99 catalyzed by Lewis base and Brønsted base (Scheme 38). According to the proposed mechanism, the nucleophilic reaction of $\mathrm{Bu}_{3} \mathrm{P}$ with $\mathrm{MBH}$ carbonate affords intermediate $\mathbf{A}$ with the concurrent release of $\mathrm{CO}_{2}$. The in situ generated tert-butoxide anion then deprotonates intermediate $\mathbf{A}$ to yield the allylic phosphonium ylids $\mathbf{B}$. Intermediate $\mathbf{D}$ is obtained by a $\boldsymbol{\gamma}$-regioselective Michael type addition between allylic phosphonium ylide $\mathbf{B}$ and aza-o-quinone methide $\mathbf{C}$ generated in situ through the $\mathrm{Cs}_{2} \mathrm{CO}_{3}-$ mediated elimination of 99. Finally, intermediate $\mathbf{D}$ undergoes an intramolecular cyclization process to afford the desired product 100 with the regeneration of $\mathrm{Bu}_{3} \mathrm{P}$ (Scheme 38$){ }^{78}$ 

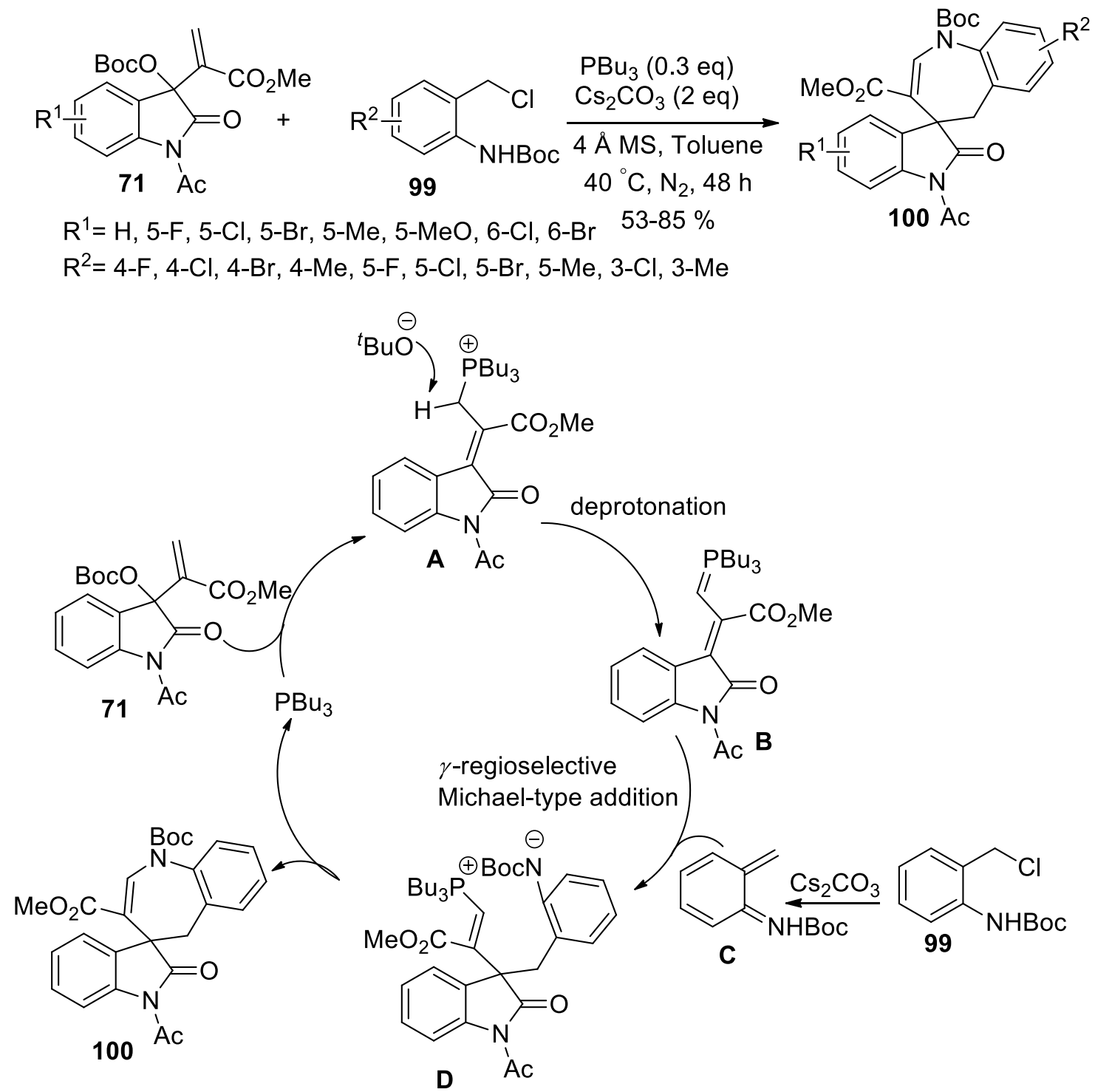

\section{Scheme 38}

\section{Synthesis Involving Multicomponent Reactions}

Reactions involving more than two components are usually referred to as multicomponent reactions (MCRs). Multicomponent reactions have emerged as powerful synthetic strategies because of their efficiency, atom economy, high selectivity and convenient construction of multiple new bonds. ${ }^{79-81}$ These characteristics give rapid access to combinatorial libraries of complex organic molecules for efficient lead structure identification and optimization in drug discovery. ${ }^{82-84}$ This section reviews three-, four and five-component reactions of isatins that have been employed in the synthesis of three- to seven membered spiro-heterocycles bearing one or more heteroatoms.

\subsection{Three-membered heterocycles}

The three-component reaction of isatins 1, N-substituted aziridine 101 and 2-(trimethylsilyl)aryl triflate 102 was carried out for the synthesis of trisubstituted $N$-aryl $\alpha$-amino epoxides 103 (Scheme 39). ${ }^{85}$ 


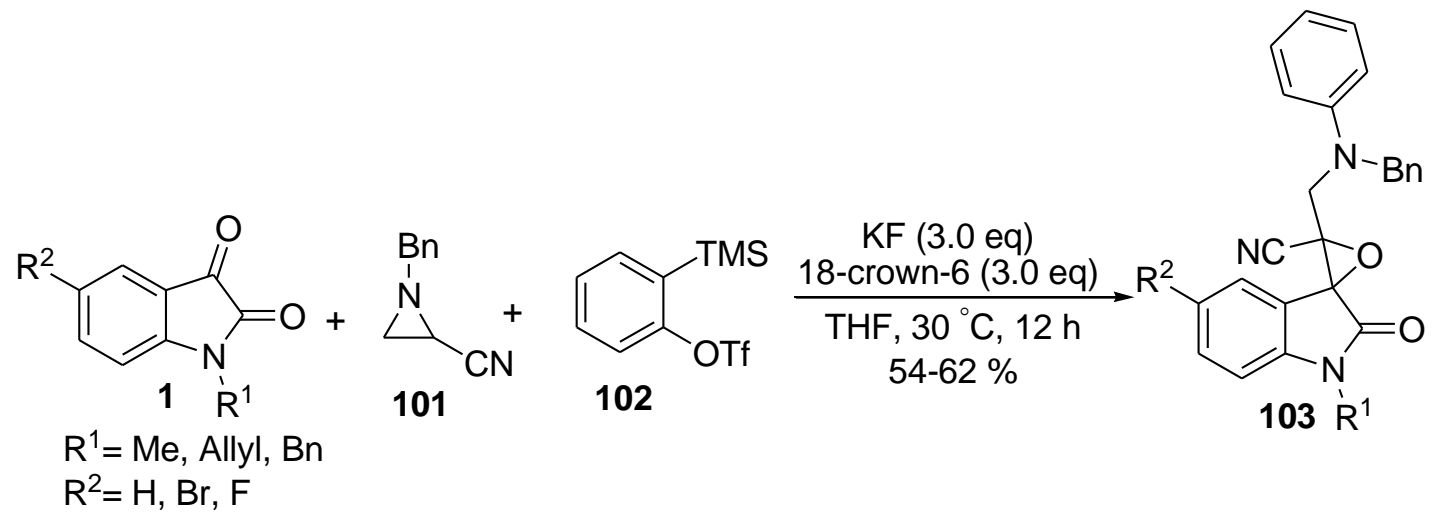

\section{Scheme 39}

\subsection{Five-membered heterocycles}

Kumar and co-workers reported the microwave-assisted three-component 1,3-dipolar cycloaddition reaction of isatin 1, 1-allyl-3,5-bis(4-methoxyphenylmethylidene)piperidin-4-one 104 and thioproline 105 for the regioselective synthesis of dispiro oxindole-pyrrolothiazole-piperidones 106 (Scheme 40). ${ }^{86}$

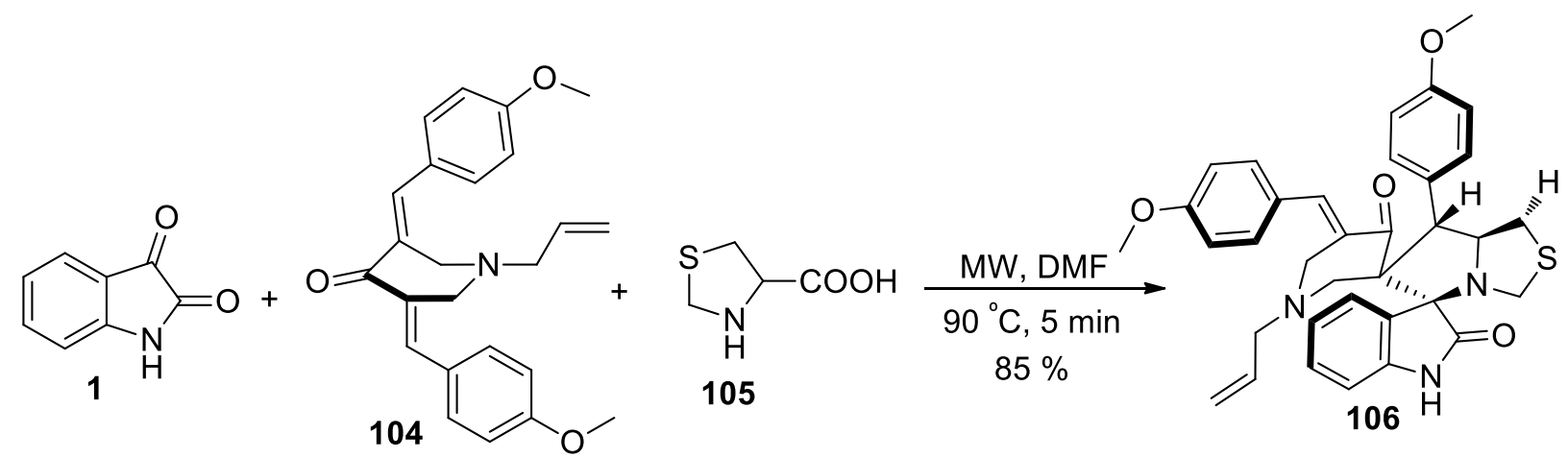

\section{Scheme 40}

Liu et al. developed a method for the synthesis of isoxazole-fused spiropyrrolidine oxindoles 110-112 via a 1,3-dipolar cycloaddition reaction of azomethine ylides (thermally generated in situ from isatin 1 derivatives and proline 107/ thioproline 105/ sarcosine 108) with 3-methyl-4-nitro-5-alkenyl-isoxazoles 109 (Scheme 41). ${ }^{87}$ The products showed considerable cytotoxicities against human prostate cancer cells PC-3, human lung cancer cells A549 and human leukemia cells K562.

The multicomponent 1,3-dipolar cycloaddition reaction of azomethine ylides (generated in situ from isatin derivatives 1 and sarcosine 108) with dienones 113 was carried out and novel turmerone motif fused spiropyrrolidine oxindoles 114 were obtained in high yields and good diastereoselectivity (up to >20:1) (Scheme 42). ${ }^{88}$ The biological activity test results demonstrated that most of the compounds showed considerable cytotoxicities to cell lines of $\mathrm{K} 562$ and A549, showed comparably potent or even more potent than the positive control of cisplatin (up to 5.1 times). 


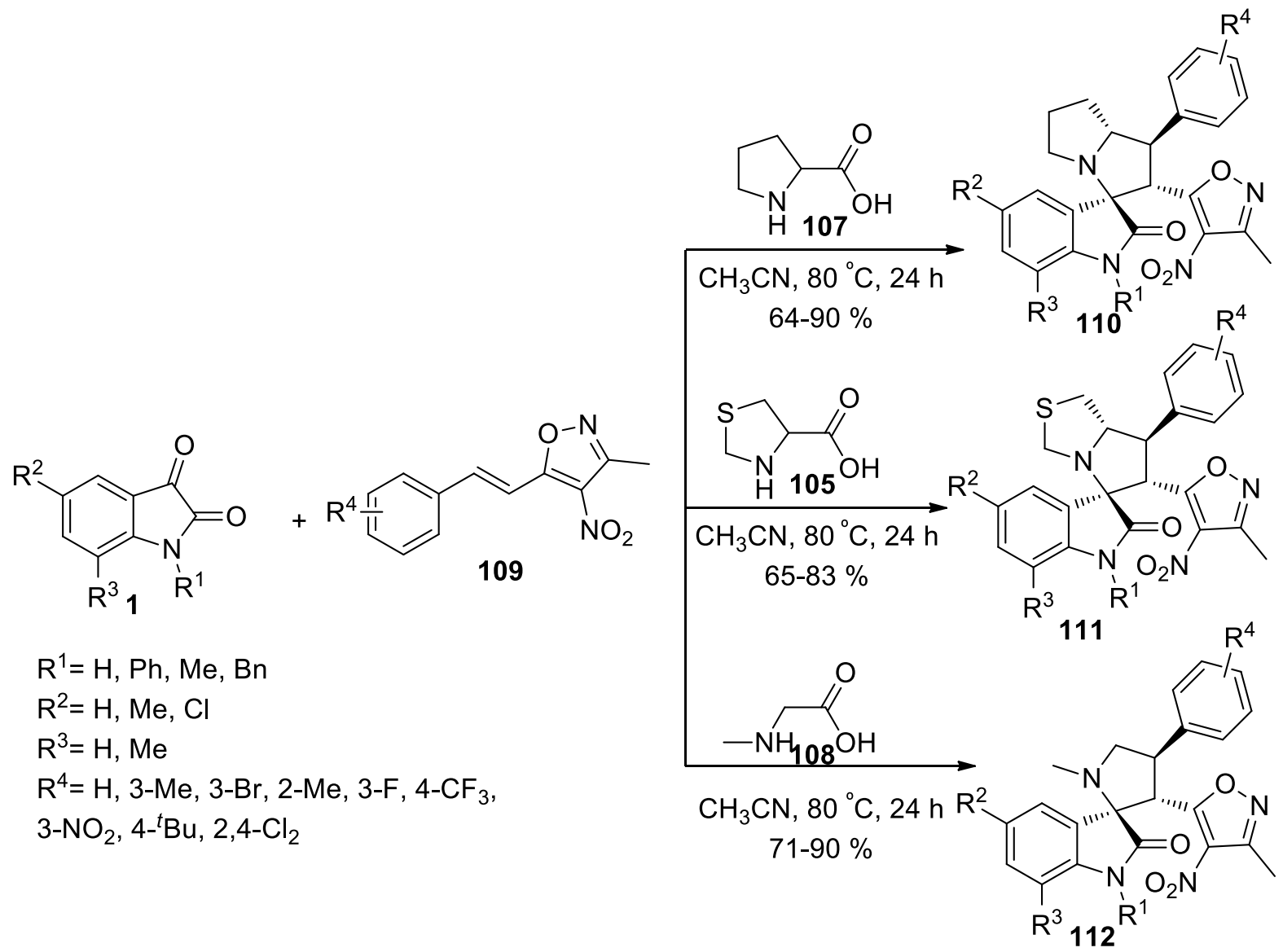

\section{Scheme 41}

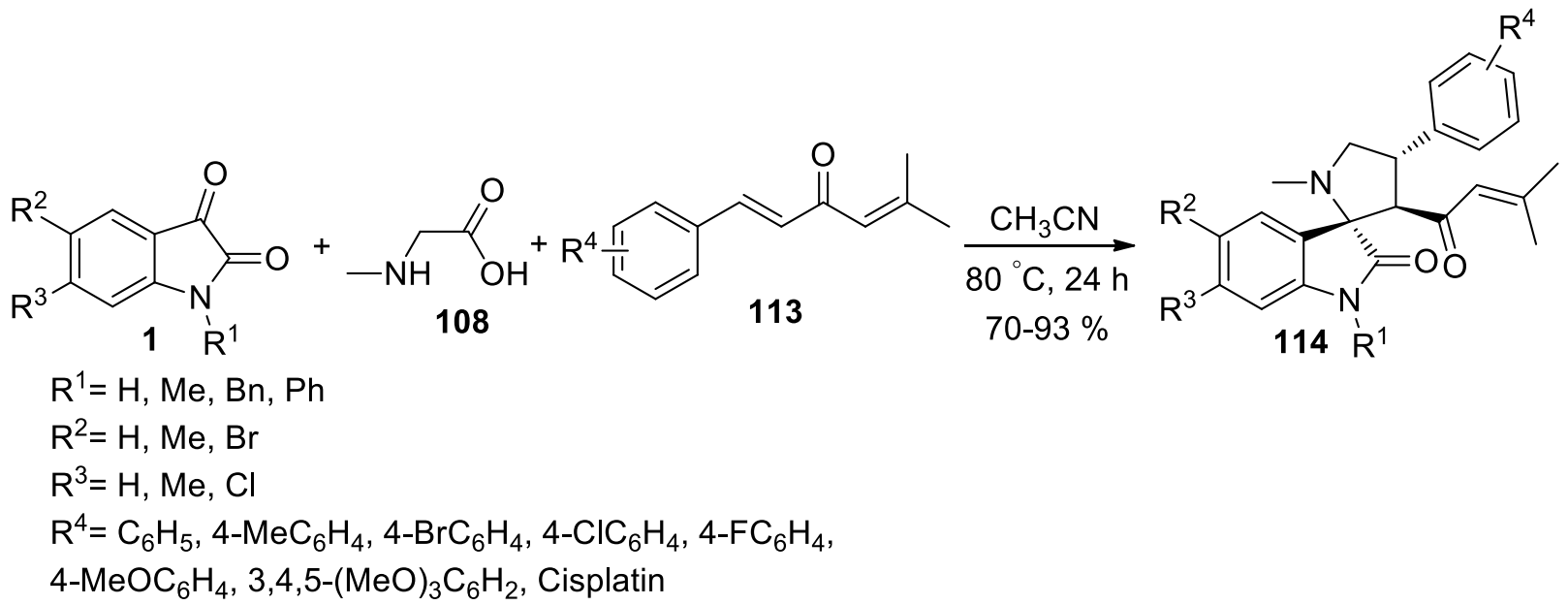

\section{Scheme 42}

Novel spiro-tethered pyrazolo[3,4-b]quinoline hybrids $\mathbf{1 1 7 - 1 1 9}$ from the reaction of isatin $1, \alpha$-amino acids $(108,105,116)$ and 6-arylidene-pyrazolo[3,4-b]quinolin-5-ones 115 , have been synthesized (Scheme 43). ${ }^{89}$ 
<smiles>O=C1Nc2ccccc2C1=O</smiles>

$\mathrm{R}^{1}=\mathrm{H}, \mathrm{Cl}, \mathrm{Me}, \mathrm{CN}$

$\mathrm{R}^{2}=4-\mathrm{Me}, 4-\mathrm{MeO}, 4-\mathrm{F}, 4-\mathrm{Cl}, 2-\mathrm{Cl}, 3-\mathrm{Br}, 2,4-\mathrm{Cl}_{2}$

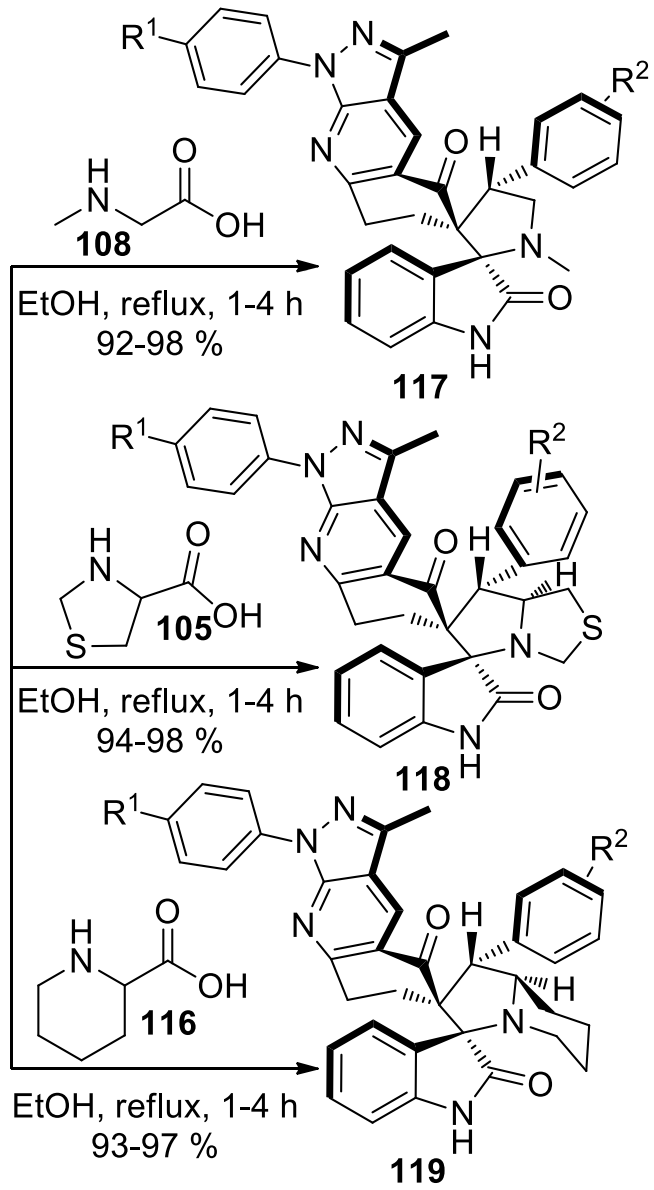

\section{Scheme 43}

A series of novel functionalized dispirooxindoles 121, 122 have been synthesized through 1,3-dipolar cycloaddition of an azomethine ylide formed from isatins 1 and various amino acids such as sarcosine 108 and proline 107 with 4-arylmethylene-2-pyrrolin-5-one 120 under microwave irradiation conditions (Scheme 44). ${ }^{90}$

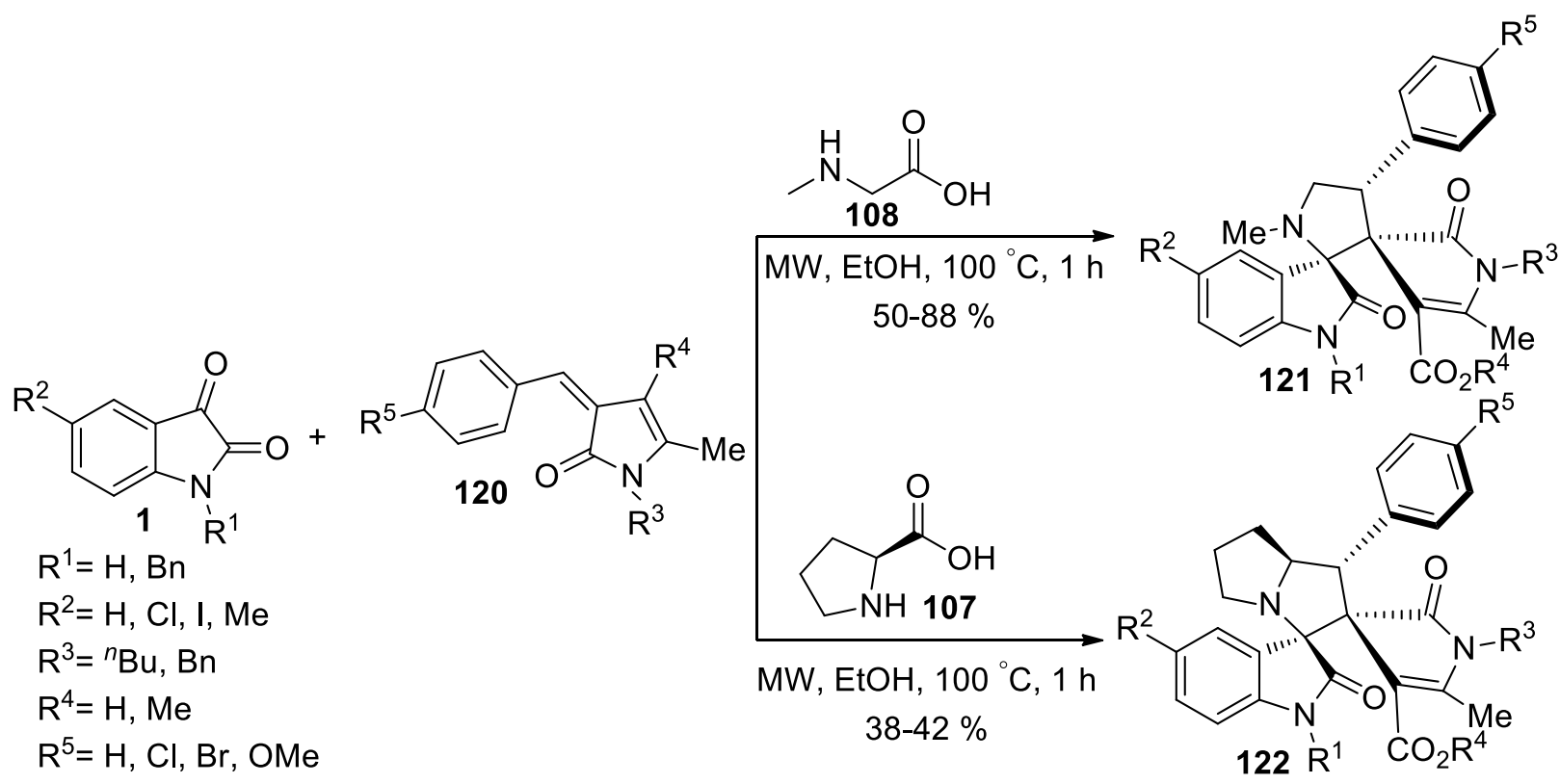

Scheme 44 
The spirooxindole-pyrrolidine/piperidine fused nitrochromanes 124 were synthesized via cycloaddition reaction of isatin 1, proline 107 and nitrochromene $\mathbf{1 2 3}$ (Scheme 45). ${ }^{91}$ The regio- and stereo-chemical results were ascertained by X-ray crystallographic study.

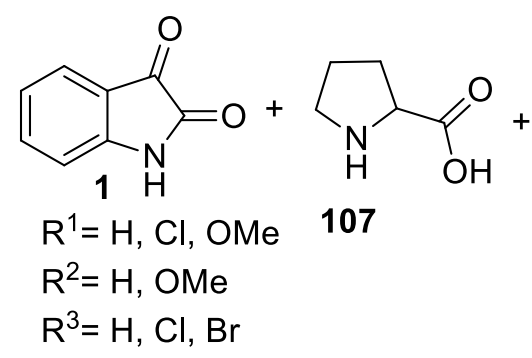<smiles>[R]c1cc2c(c([R])c1[R])OC(c1ccccc1)C([N+](=O)[O-])=C2</smiles>
123

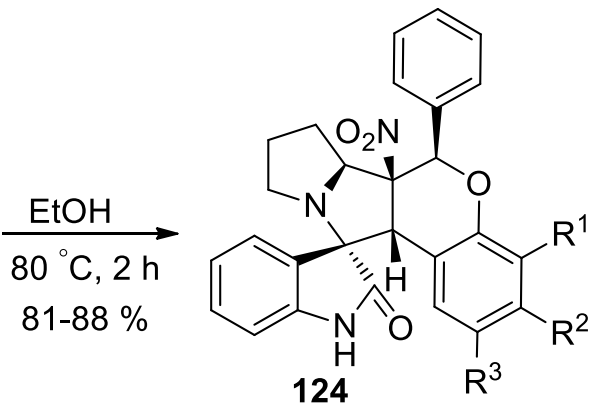

\section{Scheme 45}

The indole-based compounds $\mathbf{1 2 6}$ were obtained through the multi-component reaction of azomethine ylides (generated through condensation of isatins 1 with sarcosine 108) with 1-alkyl-3,5-bis(arylidene)-4piperidones 125 (Scheme 46). ${ }^{92} \mathrm{X}$-ray studies of products provided good support for the regio- and stereoselectivity of the reaction. Many of the synthesized spiro-indoles exhibit antitumor properties against HeLa (cervical cancer) cell line.<smiles>[R]C=C1CN([R2])C/C(=C\[R17])C1=O</smiles>

$\mathrm{R}^{1}=\mathrm{Ph}, 4-\mathrm{ClC}_{6} \mathrm{H}_{4}, 2,4-\mathrm{Cl}_{2} \mathrm{C}_{6} \mathrm{H}_{3}, 4-\mathrm{FC}_{6} \mathrm{H}_{4}, 4-\mathrm{MeC}_{6} \mathrm{H}_{4}$, 4- $\mathrm{MeOC}_{6} \mathrm{H}_{4}, 2,5-(\mathrm{MeO})_{2} \mathrm{C}_{6} \mathrm{H}_{3}$, 2-Thienyl, 3-Pyridinyl $\mathrm{R}^{2}=\mathrm{Me}, \mathrm{Et}, \mathrm{Bn},{ }^{n} \mathrm{Pr}$ $\mathrm{X}=\mathrm{CH}_{2}, \mathrm{NMe}, \mathrm{O}$

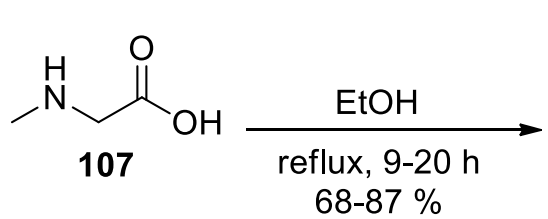

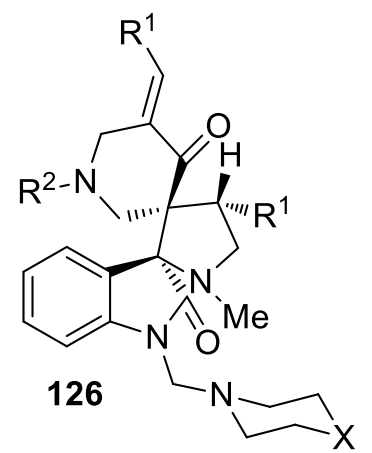

\section{Scheme 46}

The regio- and stereoselective fashion three-component 1,3-dipolar cycloaddition of azomethine ylides generated in situ from the condensation of isatins 1 and secondary amino acids (sarcosine 108/L-thioproline 105) with 3-arylidenethiochroman-4-ones $\mathbf{1 2 7}$ resulted in the formation of a series of novel dispiro compounds containing oxindole pyrrolidine/oxindolopyrrolothiazole-thiochroman-4-one hybrid frameworks 128, 129 (Scheme 47). ${ }^{93}$ 


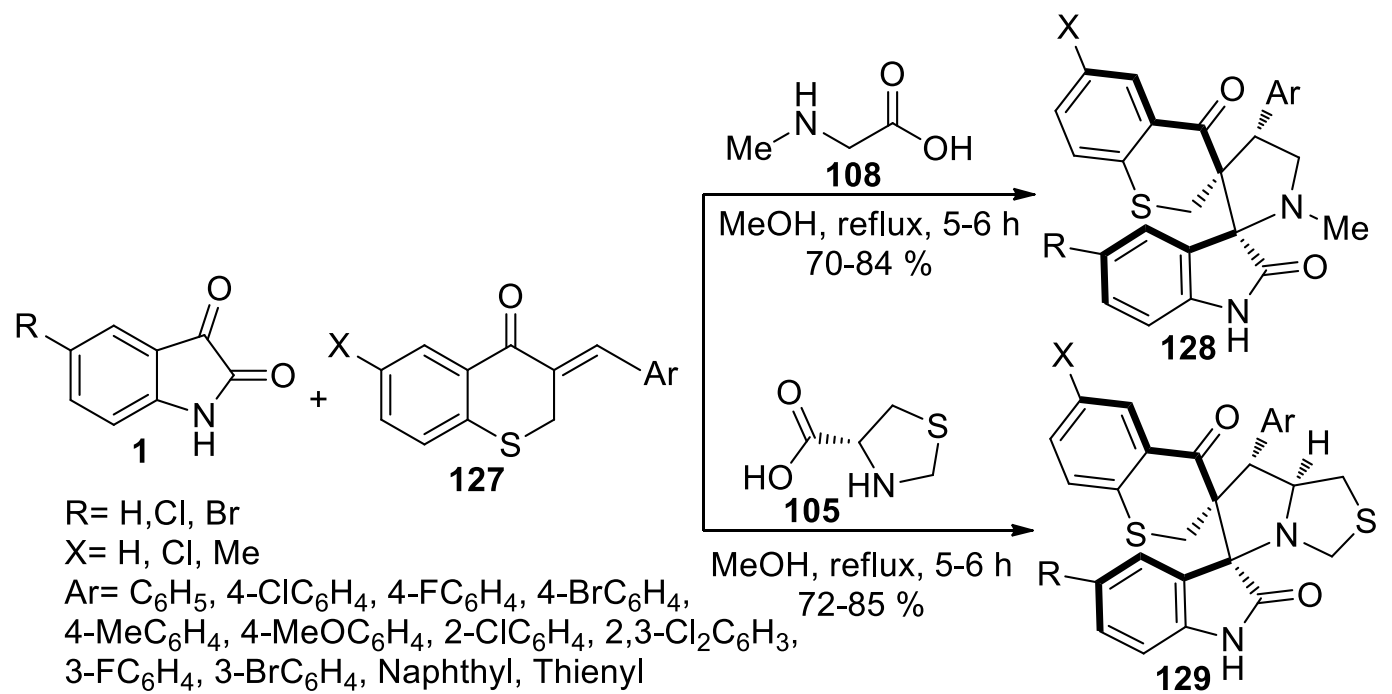

\section{Scheme 47}

Mohan's group described the synthesis of new and highly functionalized regio- and stereoselective bisoxindole-containing dispiropyrrolidinyl/thiapyrrolizidinyl hybrid molecules 131, 132 obtained through 1,3dipolar cycloaddition reactions of azomethines (generated in situ from isatin 1 and sarcosine 108 or thioproline 105) with (E)-3-((2-methoxyquinolin-3-yl)-methylene)indolin-2-one dipolarophiles 130 (Scheme 48). ${ }^{94}$ All synthesized compounds were evaluated for their in vitro antioxidant activities.<smiles>O=C1Nc2ccccc2C1=O</smiles>

$\mathrm{R}^{1}=\mathrm{H}, \mathrm{Me}$ $\mathrm{R}^{2}=\mathrm{H}, \mathrm{Me}, \mathrm{OMe}$<smiles>[R]c1cc([R])c2nc(OC)c(/C=C3/C(=O)Nc4ccccc43)cc2c1</smiles>
130

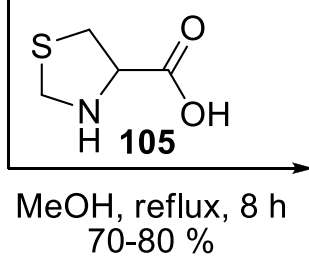

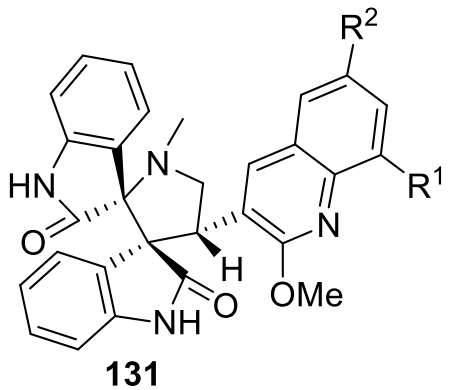

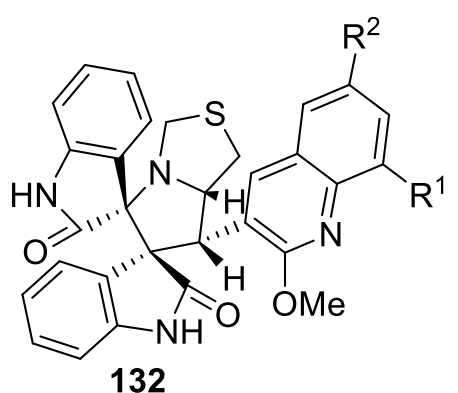

\section{Scheme 48}

Hamama et al. described the azomethine cycloaddition reactions to the synthesis of dispiro[indoline-3,2'pyrrolidine-3', $3^{\prime}$-quinoline] 134 using isatin 1, sarcosine 108, and $\alpha, \beta$-unsaturated ketone 133 (Scheme 49). From the calculations using frontier orbital theory, the authors found that the endo cycloaddition intermediate has a binding energy with $42.9 \mathrm{Kcal} / \mathrm{mol}$ more negative value than the exo cycloaddition intermediate. 
Because the benzene ring of arylidene and the benzene ring of azomethine ylid are parallel to each other, the endo cycloaddition intermediate is more stable than the exo cycloaddition intermediate, and the dispiro endocycloaddition is formed while the dispiro exo-cycloaddition product is not formed by exocycloaddition (Scheme 49). ${ }^{95}$

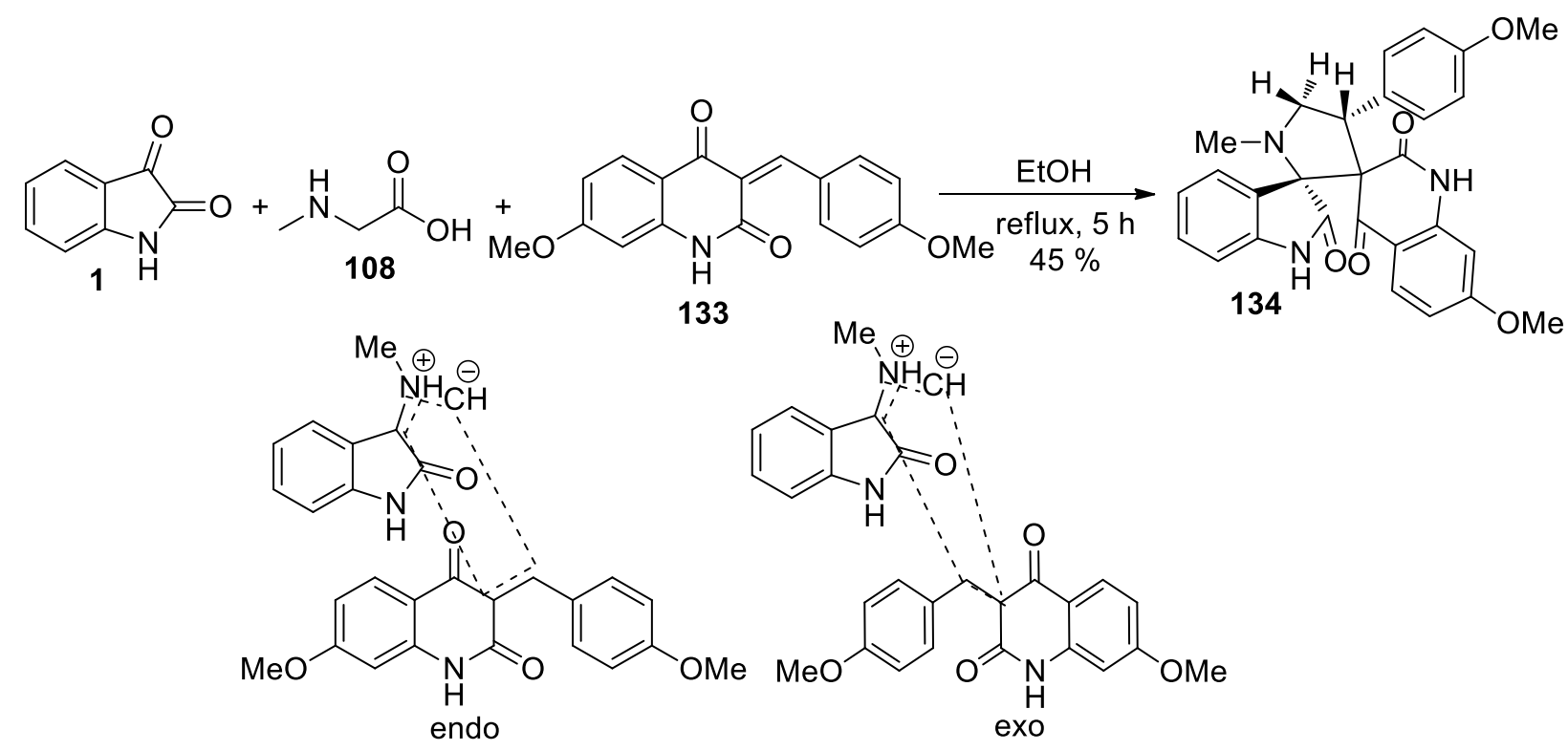

\section{Scheme 49}

The reaction of $(2 E, 4 E)$-ethyl 5-(phenylsulfonyl)penta-2,4-dienoate 135 as a dipolarophile with in situ generated azomethine ylides from isatin 1 and sarcosine 108 derivatives in refluxing 1,4-dioxane furnished the cycloadducts 136 in good yields (Scheme 50). ${ }^{96}$<smiles>O=C/C=C/C=C/S(=O)(=O)c1ccccc1</smiles>

$\mathrm{R}=\mathrm{Me}, \mathrm{Et}, \mathrm{Bn}, \mathrm{Ph}, \mathrm{Tr}$<smiles>O=C1Nc2ccccc2C1=O</smiles>

1

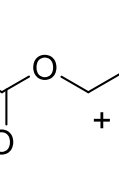

(1)<smiles>[R]NCC(=O)O</smiles><smiles>[R]N1C[C@H](S(=O)(=O)c2ccccc2)[C@@H](/C=C/C(=O)OCC)[C@]12C(=O)Nc1ccccc12</smiles>

\section{Scheme 50}

Through the reaction of isatin derivatives 1, benzyl amines 55 and (Z)-3-(2-oxo-2-phenylethylidene)indolin2-one 137 using ceric ammonium nitrate (CAN), the functionalized spirooxindole-pyrrolidines 138 were synthesized (Scheme 51). ${ }^{97}$ All the synthesized products showed good antimicrobial activity. 
<smiles>[R]c1ccc2c(c1)C(=O)C(=O)N2</smiles><smiles>[R2]c1ccc(CN)cc1</smiles>

$\mathrm{R}^{1}=\mathrm{H}, \mathrm{Cl}, \mathrm{Br}, \mathrm{I}, \mathrm{Me}, \mathrm{OMe}, \mathrm{NO}_{2}$<smiles>O=C1Nc2ccccc2/C1=C/C(=O)c1ccccc1</smiles><smiles>[R2]c1ccc([C@@H]2N[C@]3(C(=O)Nc4ccc([Y15])cc43)[C@H](C(=O)c3ccccc3)[C@@]23C(=O)Nc2ccccc23)cc1</smiles>
$\mathrm{R}^{2}=\mathrm{H}, \mathrm{F}, \mathrm{OMe}$

\section{Scheme 51}

Spiro[indoline-3,2'-pyrrole] derivatives were obtained from the reaction of isatins $1, \alpha$-amino acids 108 and phenylpropiolic acid esters 139 in refluxing isopropanol in high regioselectivity and yields. A plausible mechanism for this multicomponent reaction was proposed (Scheme 52). ${ }^{98}$ First, the condensation of isatin 1 with sarcosine 108 afforded the corresponding azomethine ylide A. Subsequently, the protic solvent of isopropanol would promote the decarboxylation of azomethine ylide $\mathbf{A}$ to form the 1,3-dipole $\mathbf{B}$. Then, the 1,3dipolar cycloaddition of intermediate B with methyl 3-phenylpropiolate 139 results in the final product spiro[indoline-3,2'-pyrrole] 140.

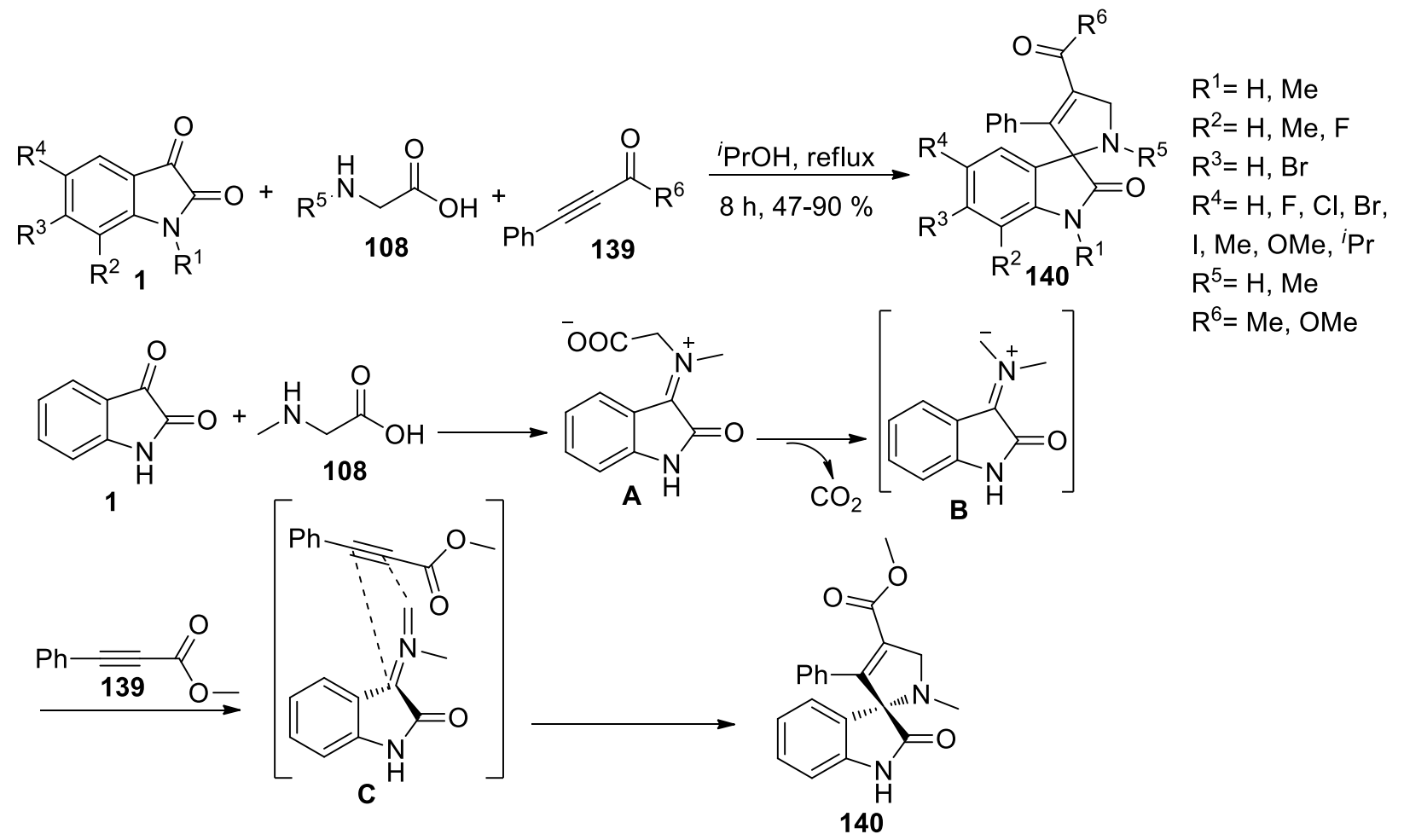

\section{Scheme 52}

Shi and co-workers developed an asymmetric chemoselective 1,3-dipolar cycloaddition of azomethine ylide with imines via the three component reaction of isatin-derived imines 31, aldehydes 11 and amino-ester 
141 in the presence of chiral phosphoric acid. In this reaction, spiro[imidazolidine-2,3'-oxindole] frameworks 142 were obtained with high diastereo and enantioselectivities (97: 3 er, all >95:5 dr) (Scheme 53). ${ }^{99}$

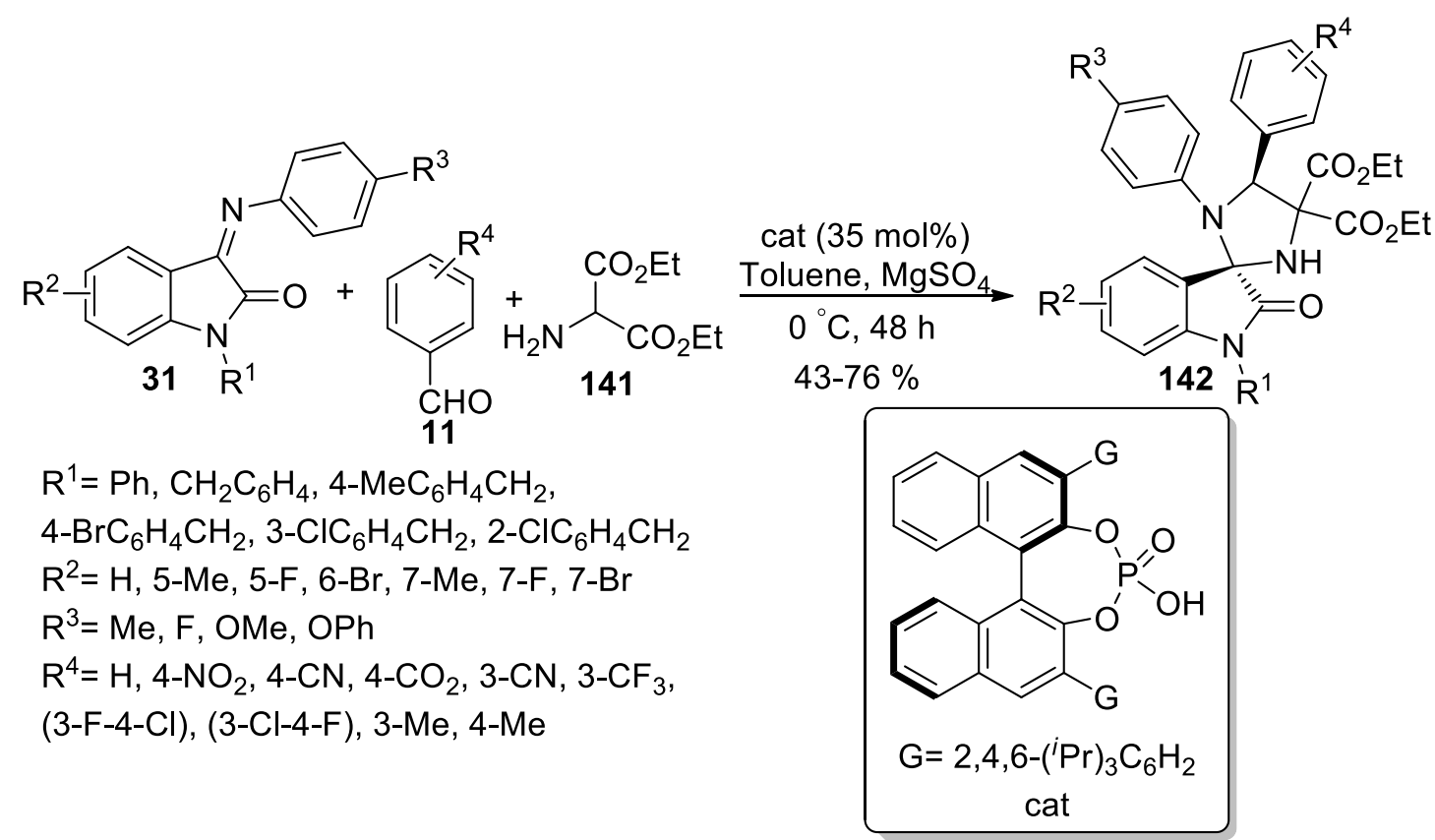

\section{Scheme 53}

Safaei-Ghomi and Zahedi reported application of $\mathrm{Fe}_{3} \mathrm{O}_{4}$-L-proline NPs as a chiral catalyst to achieve high diastereoselectivities in the asymmetric 1,3-dipolar cycloaddition reaction of isatins $1, N$-arylhydroxylamines 143 and enones 83 for the synthesis of spiroisoxazolidines 144 (Scheme 54). ${ }^{100}$

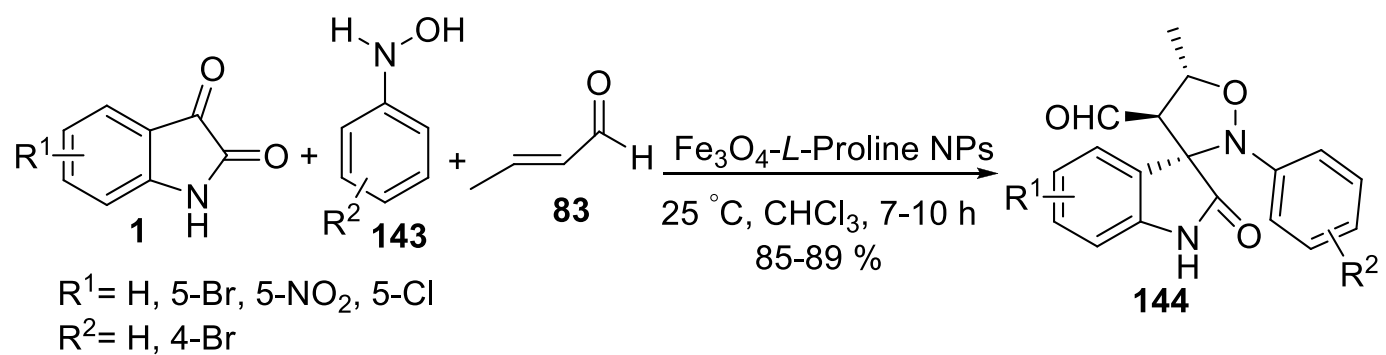

\section{Scheme 54}

DBSA ( $p$-dodecylbenzenesulfonic acid) as an efficient Brønsted acid surfactant combined catalyst facilitated the reaction of isatin derivatives 1 with primary amines $\mathbf{5 5}$ and thioglycolic acid 145 for the synthesis of a series of pharmacologically important spiro[indoline-3,2'-thiazolidinones] 146, 147. First, a reaction of isatin $\mathbf{1}$ and amines $\mathbf{5 5}$ was carried out to generate the corresponding Schiff base intermediate $\mathbf{A}$ and $\mathbf{B}$ which after the addition of thioglycolic acid in the same flask afforded the desired product (Scheme 55). ${ }^{101}$ 


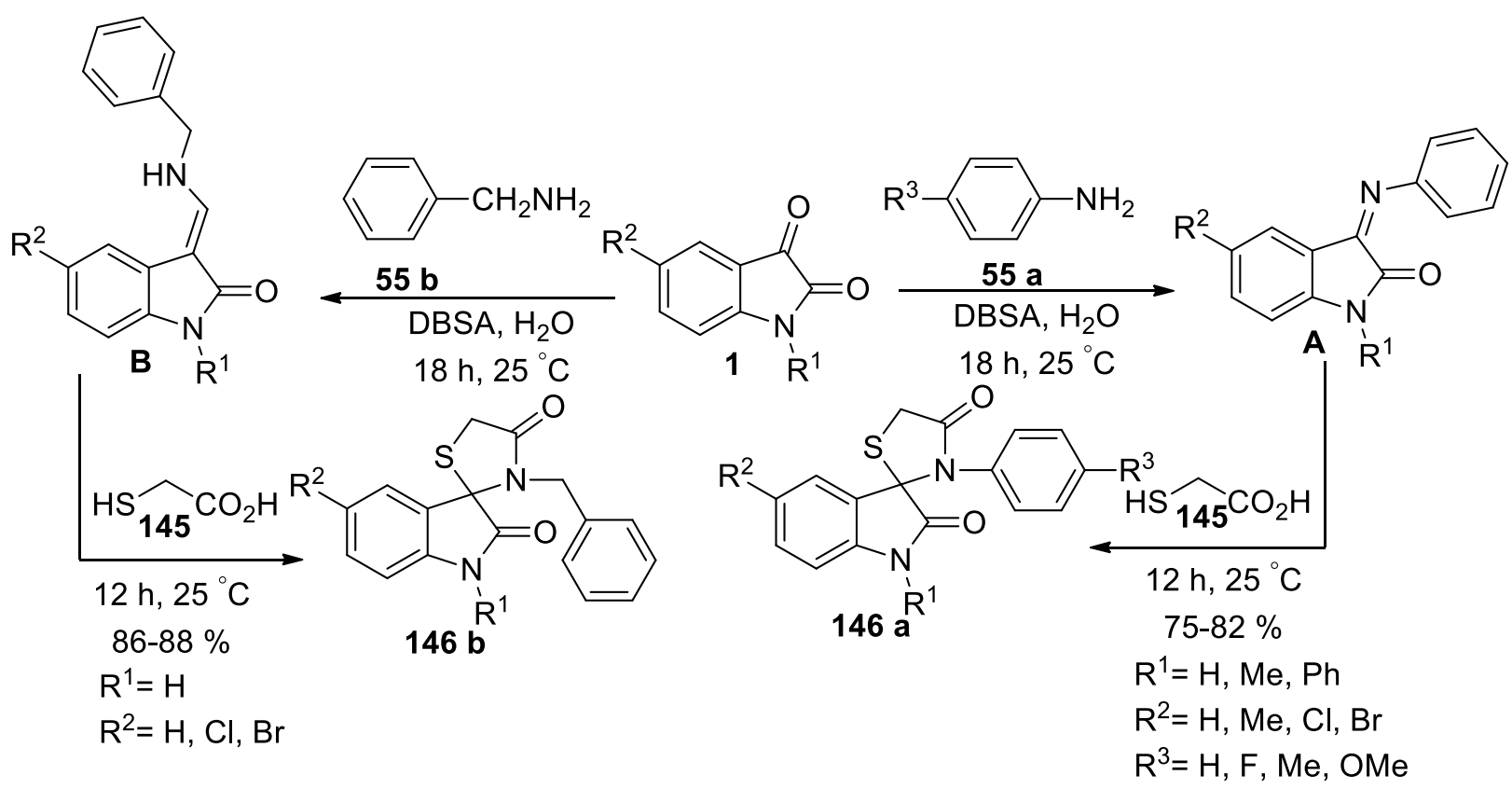

\section{Scheme 55}

Rajeswari et al. employed a one-pot four-component [3 +2 ] cycloaddition process using $N$-propargylated isatin 1, coumarin-3-carboxylic acid 147, L-proline 107/sarcosine 108 and aryl azides 148 with Cu as a catalyst to prepare the selective spirooxindole pyrrolizine linked 1,2,3-triazole conjugates 149, 150 (Scheme 56). ${ }^{102}$

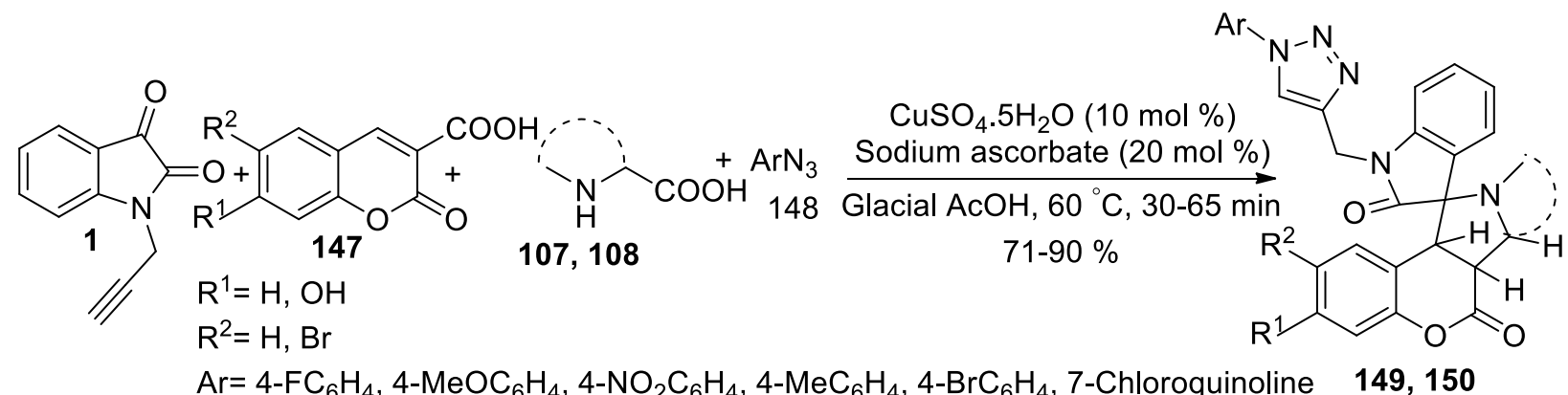

\section{Scheme 56}

Meshram's group have demonstrated an efficient and regioselective synthesis of spirooxindoles 153 from the reaction of isatins 1, $\beta$-nitrostyrenes 151 and benzylamine 55/ $\alpha$-amino acids 152 under microwave irradiation (Scheme 57). ${ }^{103}$ All products were screened for antimicrobial activity and the majority of compounds showed significant activities. 

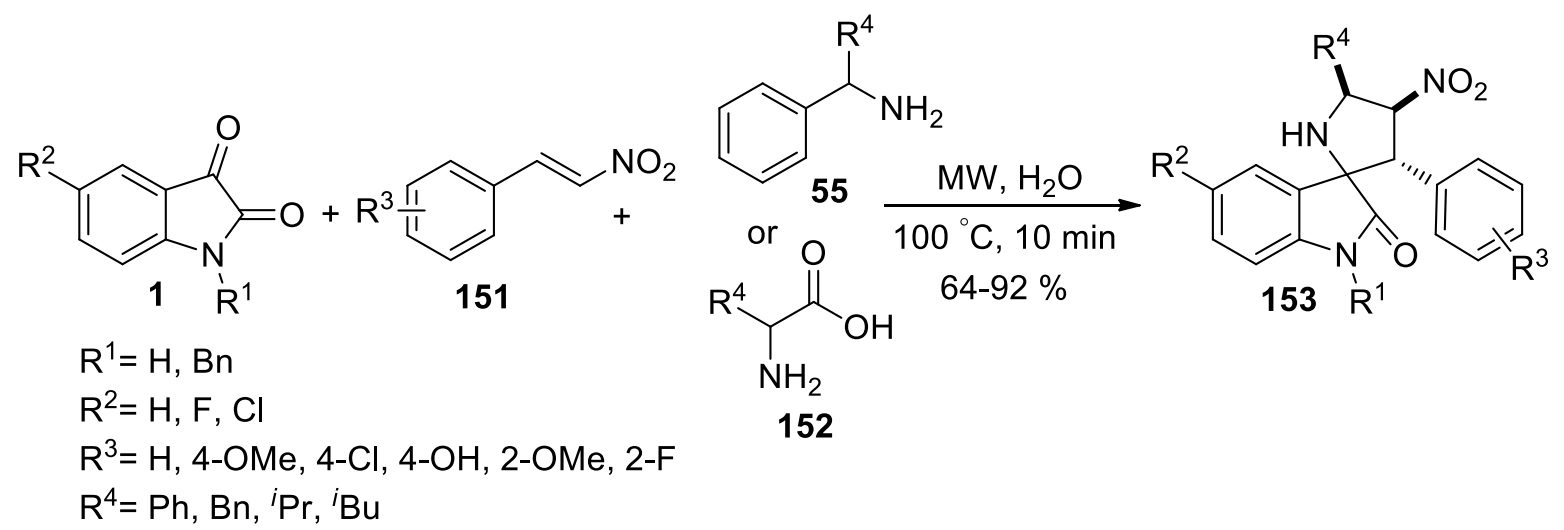

\section{Scheme 57}

Khurana's group reported the synthesis of novel heterocyclic triazolyl spirocyclic oxindoles 155 via the one-pot five component reaction of isatin 1, 1,3-dicarbonyl 154, aryl azides 148, aromatic aldehydes 11, and Lproline 107 using DBU as a catalyst in PEG-400 (Scheme 58). ${ }^{104}$

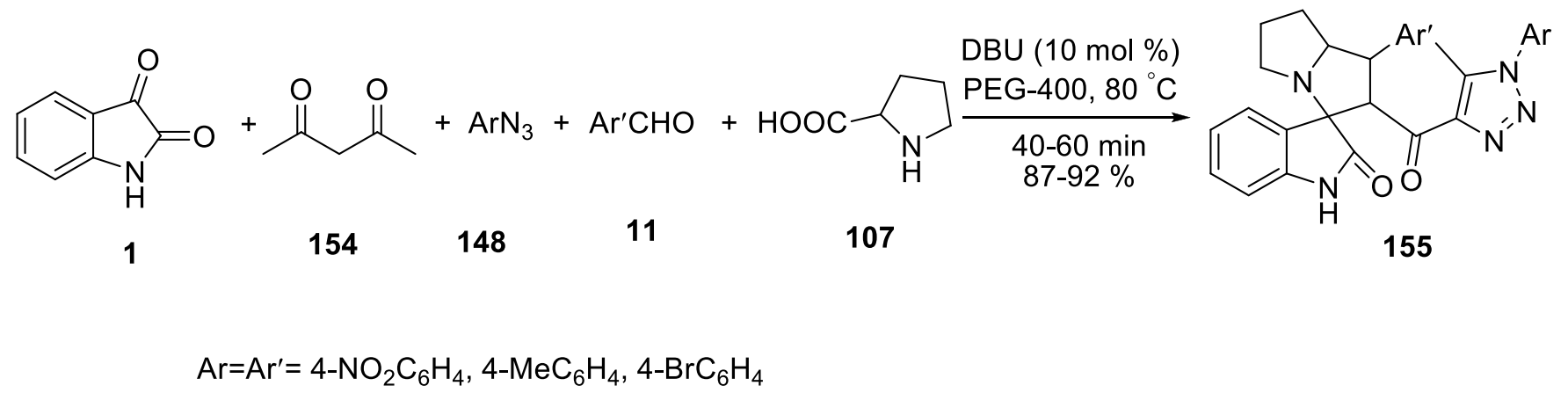

\section{Scheme 58}

\subsection{Six-membered heterocycles}

The spiro-dihydropyridine derivatives 158 were synthesized via a one-pot multicomponent condensation of isatin derivatives 1 and malononitrile 156 with ketene aminals 157 under catalyst-free conditions in PEG-400 as a highly efficient and green biodegradable polymeric medium (Scheme 59). ${ }^{105}$ All compounds showed moderate to high level activity against acetyl and butyrylcholinesterase.

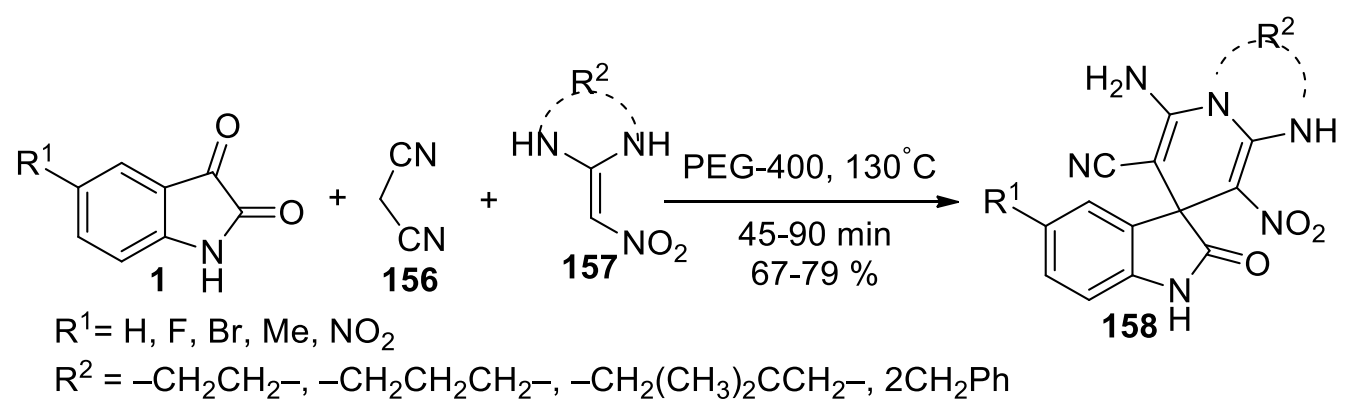

\section{Scheme 59}


Spirooxindoles incorporating a "medicinally privileged" indenopyridine moiety 161 have been synthesized regioselectively via multicomponent reaction of isatins 1, 1,1-dicyanomethylene-3-indanone 159 and malononitrile 156 in the presence of amines 160 (Scheme 60). ${ }^{106}$ The product is a spirooxindole-fused indenopyridine salt that was successfully neutralized by dilute hydrochloric acid.

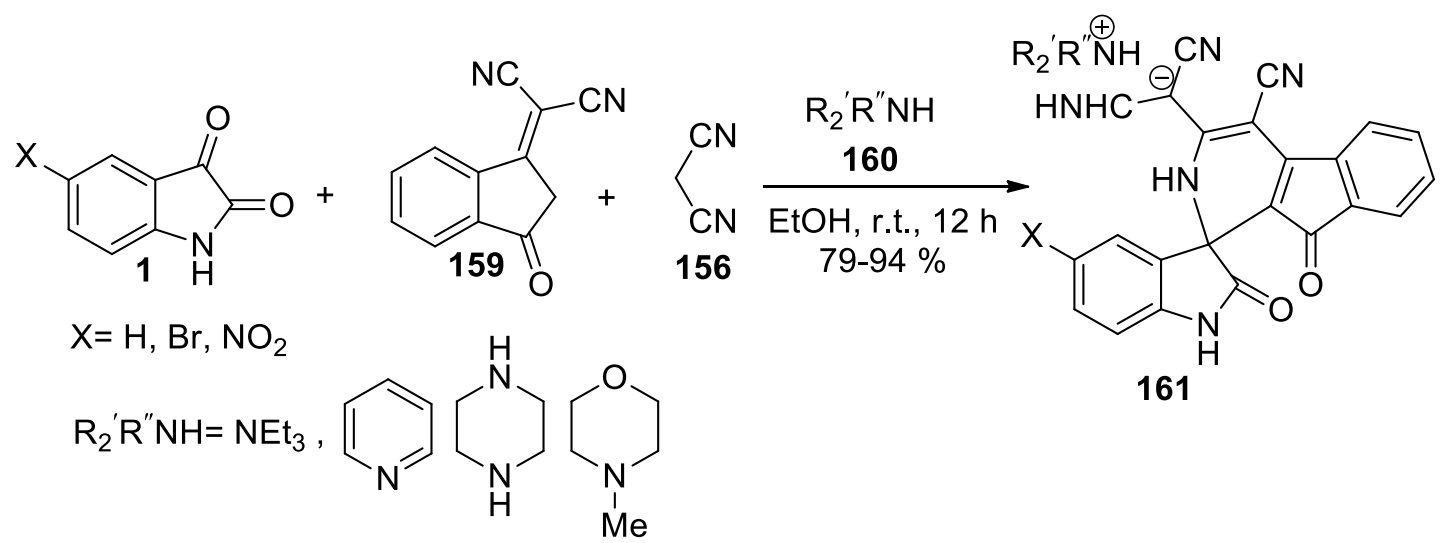

\section{Scheme 60}

Treatment of isatin derivatives 1 and barbituric acids 162 with 6-amino-1,3-dimethyl uracil 163 using SBA$15-\mathrm{Pr}-\mathrm{SO}_{3} \mathrm{H}$ as a heterogeneous nano catalyst in one pot reaction, resulted in the formation of the spirooxindole dipyrimidine derivatives 164 in high yields (Scheme 61). ${ }^{107}$<smiles>[R]c1ccc2c(c1)C(=O)C(=O)N2</smiles>

$\mathrm{R}^{1}=\mathrm{H}, \mathrm{F}, \mathrm{Cl}, \mathrm{Br}, \mathrm{I}, \mathrm{NO}_{2}$<smiles>[X]C1=[N+]([R2])C(=O)CC(=O)N1[R]</smiles>

162

$\mathrm{R}^{2}=\mathrm{H}, \mathrm{Me}$

$\mathrm{X}=\mathrm{O}, \mathrm{S}$<smiles>Cn1c(N)cc(=O)n(C)c1=O</smiles>

163

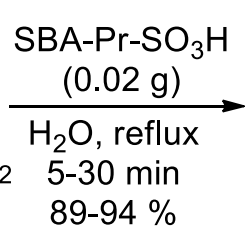
$89-94 \%$<smiles></smiles>

\section{Scheme 61}

In another study, Mohammadi Ziarani and co-workers reported a method for the synthesis of spiro indeno[1,2-b]pyrido[2,3-d]pyrimidine-5,3'-indolines 166 through the condensation reaction of isatins 1 , 6aminouracil 163 and 1,3-indanedione 165 in the presence of SBA-15- $\mathrm{Pr}-\mathrm{SO}_{3} \mathrm{H}$ as a heterogeneous nano catalyst (Scheme 62). ${ }^{108}$ The same authors also reported microwave irradiation condition for this reaction. ${ }^{109}$ 

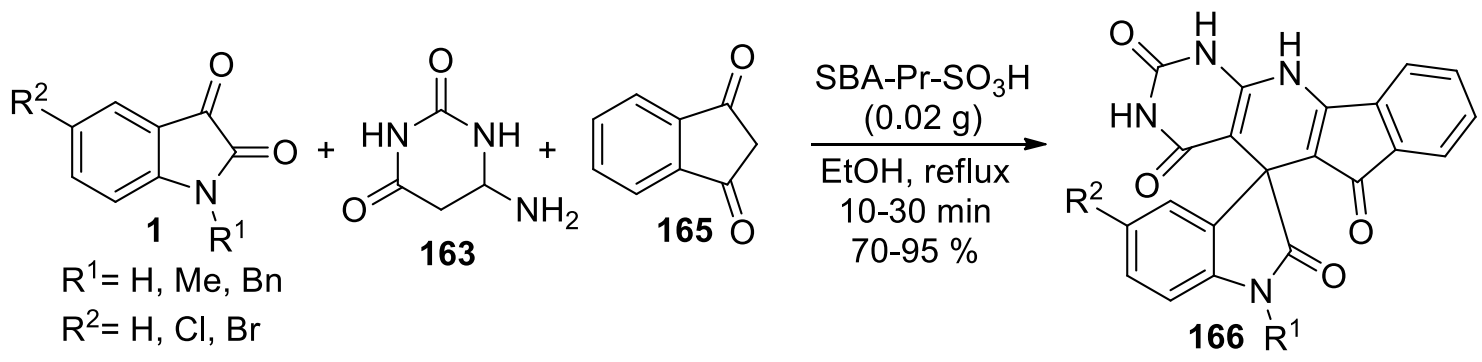

\section{Scheme 62}

Siddiqui's group prepared the pyrazolo-pyridopyrimidines 169 by the four-component reaction of isatins $\mathbf{1}$, 6-amino-1-methyluracil 163, $\beta$-ketoester 167 and hydrazines 168 in the presence of a catalytic amount of iodine (Scheme 63). ${ }^{110}$

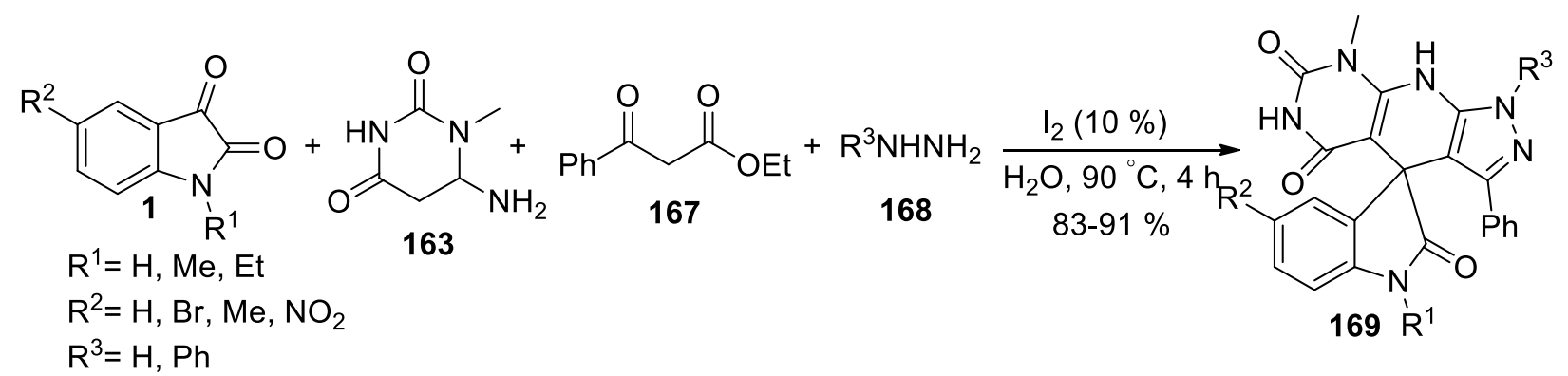

\section{Scheme 63}

An efficient methodology for the synthesis of substituted spiro[indolo-3,10'-indeno[1,2-b]quinoline]2,4,11'-triones 170 by the reaction of isatins 1, 1,3-indanedione 165, and enaminones 50 using La(OTf) 3 as catalyst in PEG-400 under conventional heating and or ultrasonic irradiation was reported by Kumari et al. (Scheme 64). ${ }^{111}$

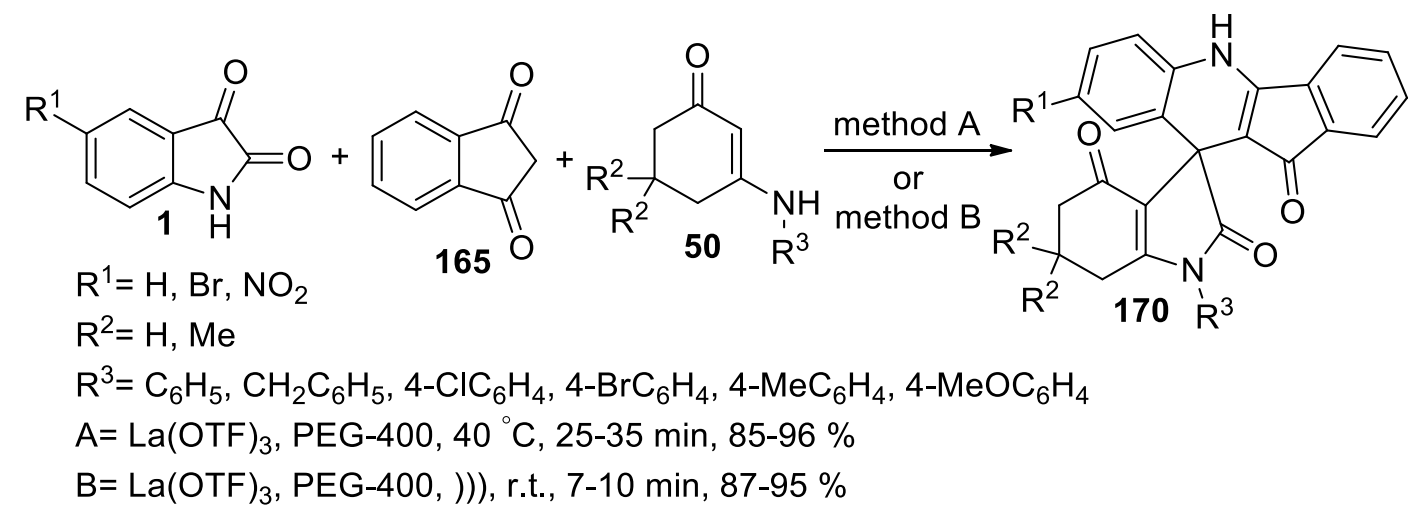

\section{Scheme 64}

Thanikachalam and co-workers prepared a spirooxindole compound namely $2^{\prime}$-amino-6'-(1H-indol-3-yl)-2oxospiro[indole-3,4'-pyran]-3',5'-dicarbonitrile 172, from the reaction of isatin 1, 2-cyanoacetylindole 171 and malononitrile 156 (Scheme 65). ${ }^{112}$ 


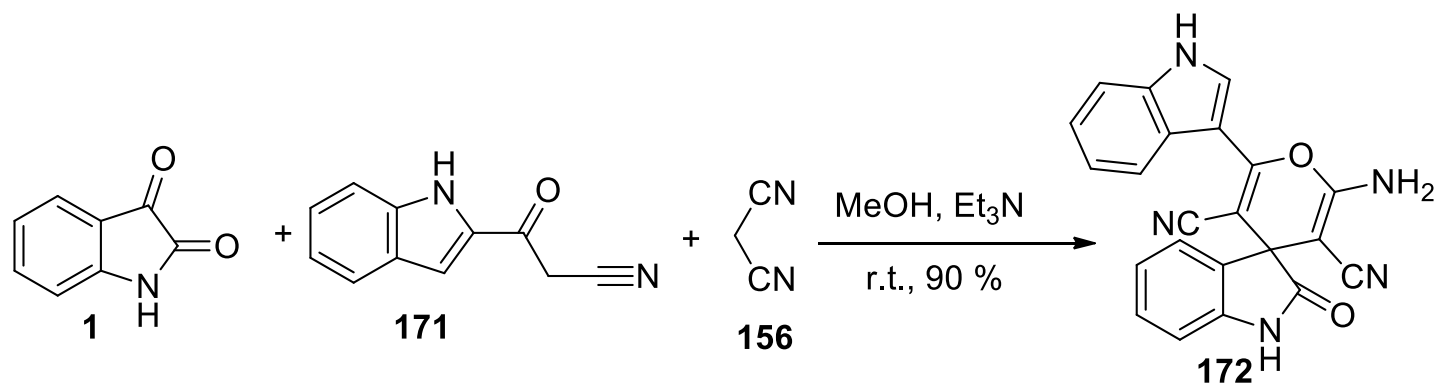

\section{Scheme 65}

The one-pot three-component condensation of isatins 1, $\alpha$ or $\beta$-naphthols 173, 174, and cyclic 1,3dicarbonyl compounds 154 in the presence of $\mathrm{Fe}_{3} \mathrm{O}_{4} @ \mathrm{MCM}-41-\mathrm{SO}_{3} \mathrm{H} @[\mathrm{HMIm}]\left[\mathrm{HSO}_{4}\right]$ as catalyst was successfully established for the synthesis of new derivatives of spiro[benzoxanthene-indoline]diones 175 (Scheme 66). ${ }^{113}$

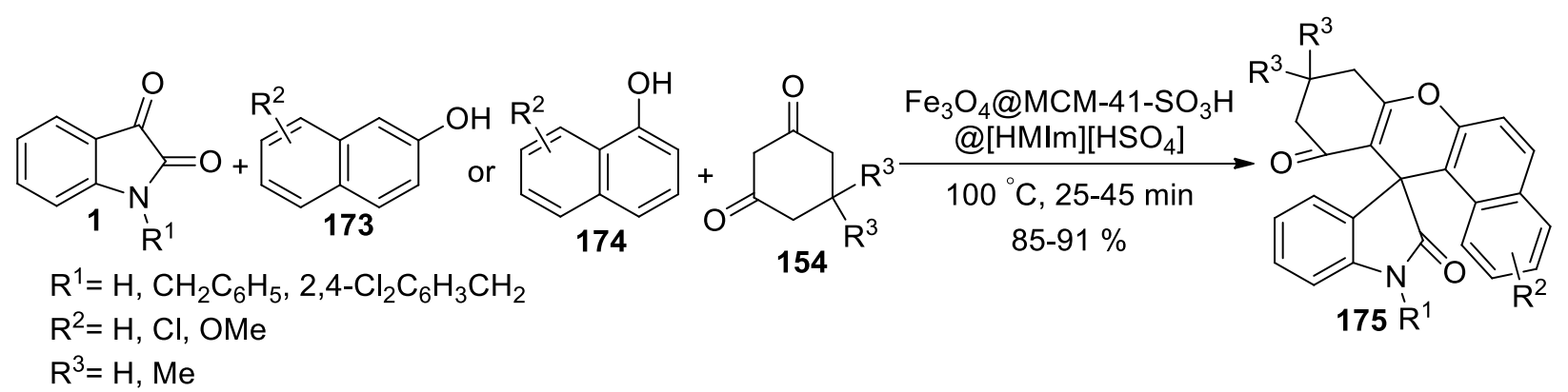

\section{Scheme 66}

Shi and Yan reported a method for the synthesis of functionalized spiro[indoline-3,4'-pyrano[3,2h]quinolines] 178 via the three-component condensation of isatins 1, 8-hydroxyquinoline 176 and malononitrile 156 or ethyl cyanoacetate 177 (Scheme 67)..$^{114}$

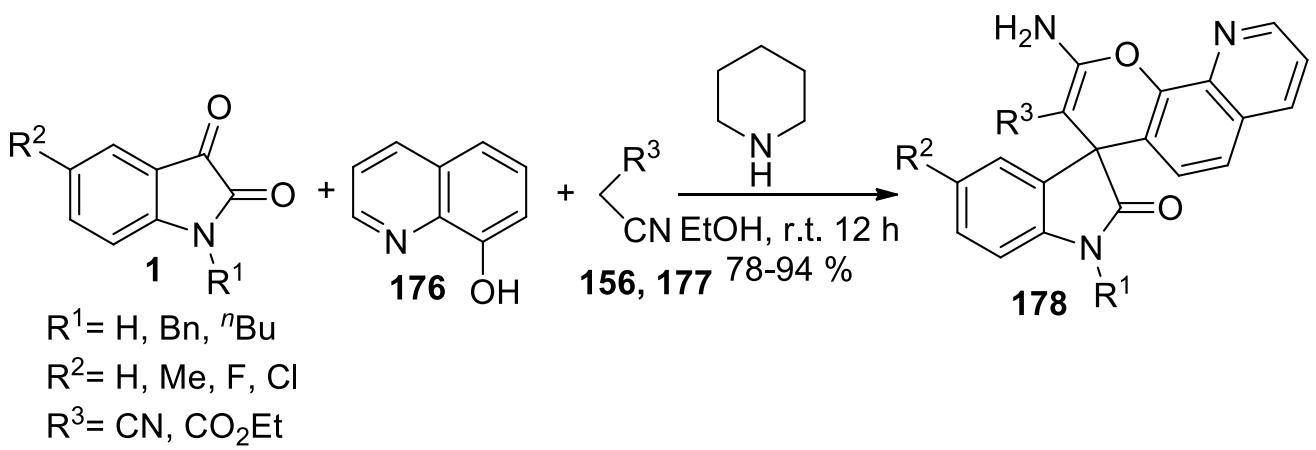

\section{Scheme 67}

A dicationic ionic liquid (IL) and $\mathrm{K}_{2} \mathrm{CO}_{3}$ were used as an efficient catalytic system for the synthesis of $4 \mathrm{H}$ pyrans 179 via the three-component condensation reaction of isatin derivatives 1 , malononitrile 156, and 1,3dicarbonyl compounds 154 in water (Scheme 68). ${ }^{115}$ This reaction has been widely studied and different 
catalysts such as $[\mathrm{Amb}] \mathrm{L}$-prolinate, ${ }^{116}$ tetrabutylammonium bromide (TBAB), ${ }^{117}$ boron nitride supported iron oxide $\left(\mathrm{BN} @ \mathrm{Fe}_{3} \mathrm{O}_{4}\right),{ }^{118} \mathrm{Al}-\mathrm{ITQ}-\mathrm{HB},{ }^{119}[\mathrm{bmim}] \mathrm{OH},{ }^{120} \mathrm{Fe}_{3} \mathrm{O}_{4},{ }^{121}$ carbon nanotube (CNT), ${ }^{122} \mathrm{NaOAc}^{123} \mathrm{CuFe}_{2} \mathrm{O}_{4}$ nanoparticles ${ }^{124}$ and trisodium citrate dihydrate ${ }^{125}$ were used in this reaction.<smiles>[R]c1ccc2c(c1)C(=O)C(=O)N2</smiles>

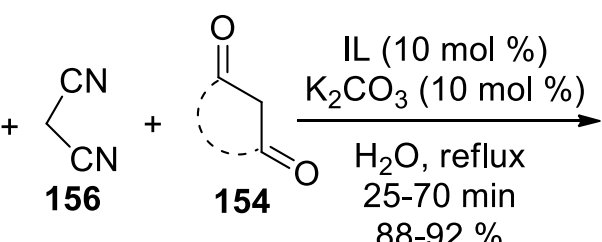<smiles>[R]c1ccc2c(c1)C1(C(=O)N2)C2=C(CCC2=O)OC(N)C1C#N</smiles>
$\mathrm{R}=\mathrm{H}, \mathrm{F}, \mathrm{Cl}, \mathrm{Br}$ $88-92 \%$ 1,3-Dicarbonyl= Dimedone, Barbituric acid, Thiobarbituric acid<smiles></smiles>

\section{Scheme 68}

The preparation of spiropyran derivatives 180 using silica-bonded 1,4-diazabicyclo[2.2.2]octane-sulfonic acid chloride (SBDBSAC) as a catalyst in multicomponent reaction of isatin derivatives $\mathbf{1}$, barbituric acids $\mathbf{1 6 2}$, and 1,3-dicarbonyl compounds 154 was reported by Moosavi-Zare and co-workers (Scheme 69). ${ }^{126}$

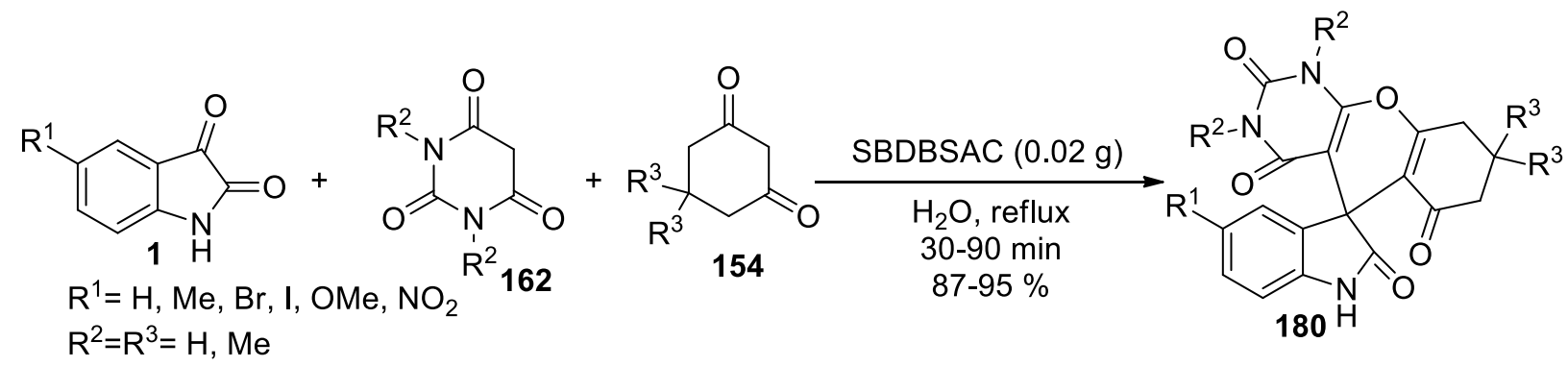

\section{Scheme 69}

The synthesis of chiral, enantioenriched spiro(indoline-pyrimidine)-dione derivatives 182 from the asymmetric, Biginelli-like reaction of $N$-substituted isatins 1 , urea 181 and $\beta$-ketoesters 167 using BINOLderived phosphoric acid as a catalyst has been studied by Stucchi et al. (Scheme 70). ${ }^{127}$ 


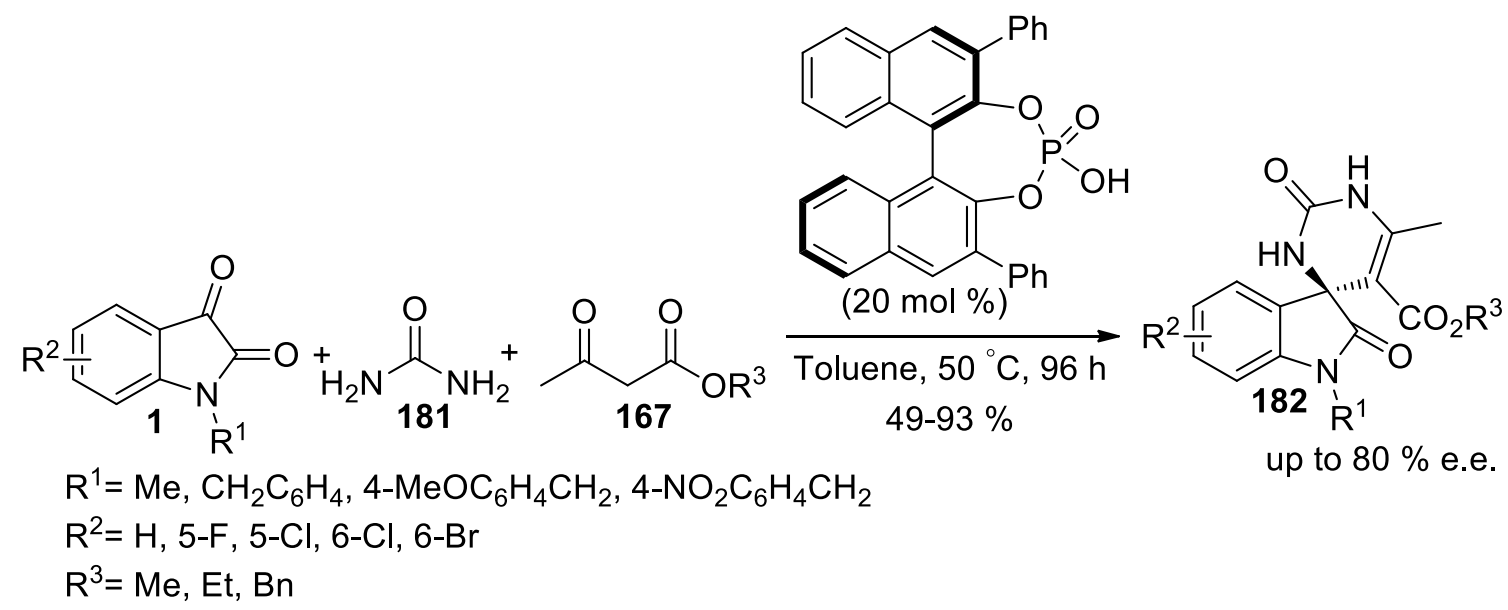

\section{Scheme 70}

A variety of spirooxindole derivatives $\mathbf{1 8 4}$ were synthesized by a facile one pot, three-component protocol using isatin 1, isatoic anhydride 183 and amines $\mathbf{5 5}$ in the presence of CuO-Pd nanoparticles as catalyst. The nucleophilic addition of aniline 55 to isatoic anhydride 183, in the presence of the CuO-Pd NPs, followed by decarboxylation, produced 2-aminobenzamide $\mathbf{A}$. The condensation of $\mathbf{A}$ with isatin $\mathbf{1}$, in the presence of $\mathbf{C u O}-$ Pd NPs, gave imine B, which on intramolecular cyclization gave the final product 184 (Scheme 71). ${ }^{128}$
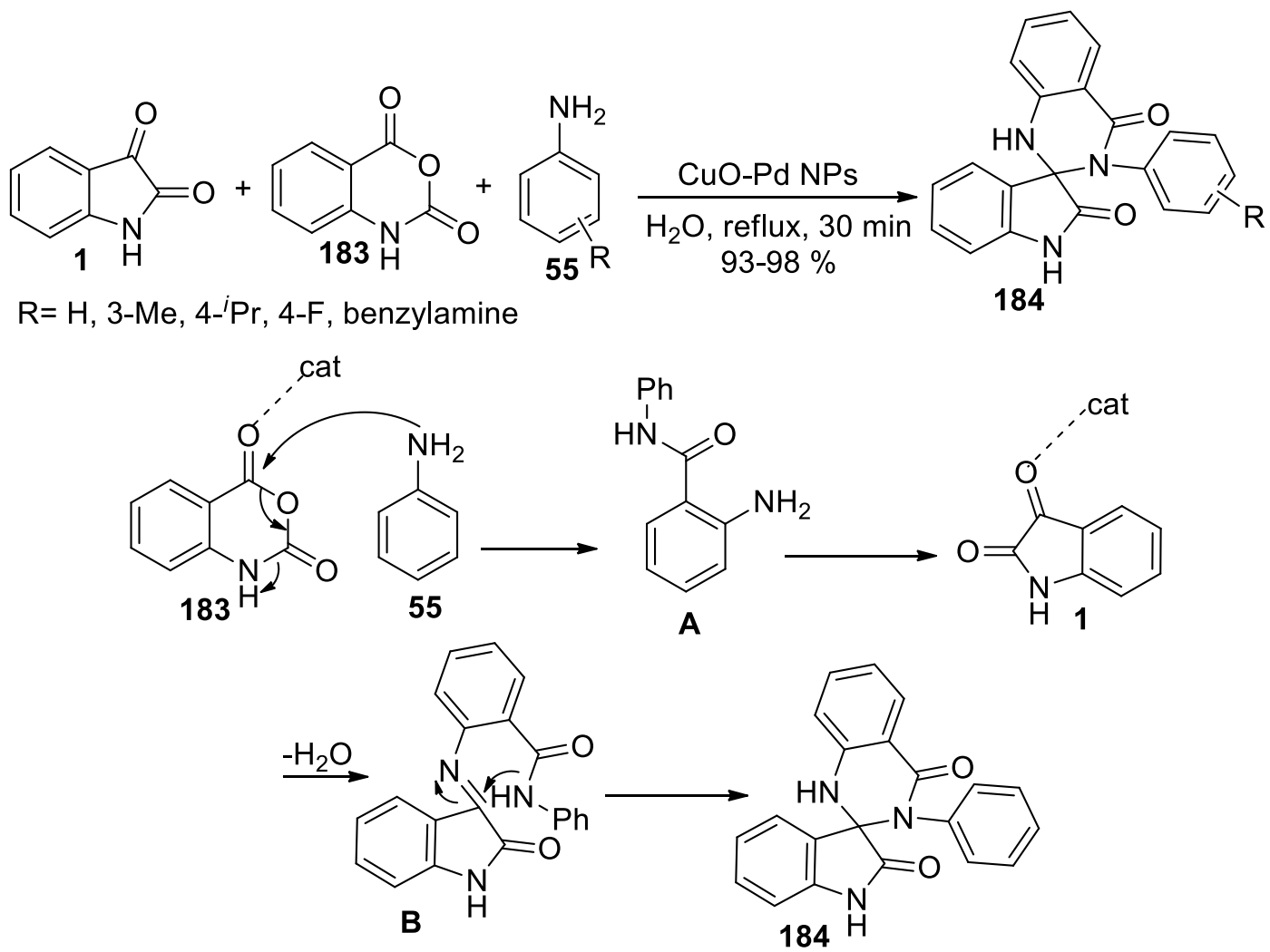

\section{Scheme 71}


Pardasani and co-workers studied a novel three-component reaction for the synthesis of spirobenzimidazoquinazolinones 186 via the reaction of isatins 1, dimedone 154 and 2-aminobenzimidazole 185 under microwave irradiation (Scheme 72). ${ }^{129}$ This one-pot process involves the formation of one $\mathrm{C}-\mathrm{C}$ and two $\mathrm{C}-\mathrm{N}$ bonds during the synthesis of the spiro-compounds as confirmed by $\mathrm{X}$-ray analysis.

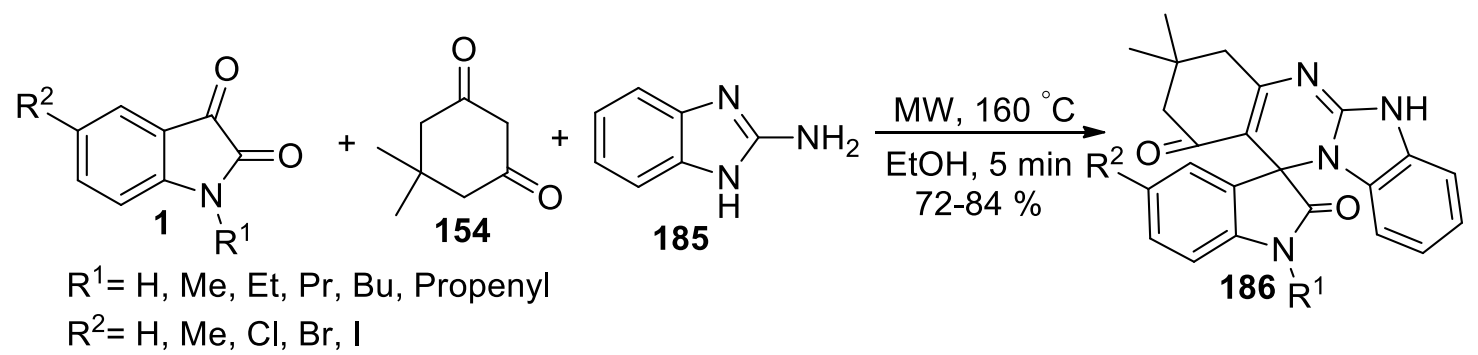

\section{Scheme 72}

Alizadeh and Moafi developed a three-component domino reaction of isatin derivatives 1, 2-aryl-2oxoethyl thiocyanates 187 and hydrazonoyl chlorides 188 that provides a convenient method for the synthesis of $4^{\prime} H$-spiro[indole-3,5'-[1,3,4]thiadiazin]-2(1H)-ones 189 (Scheme 73). ${ }^{130}$

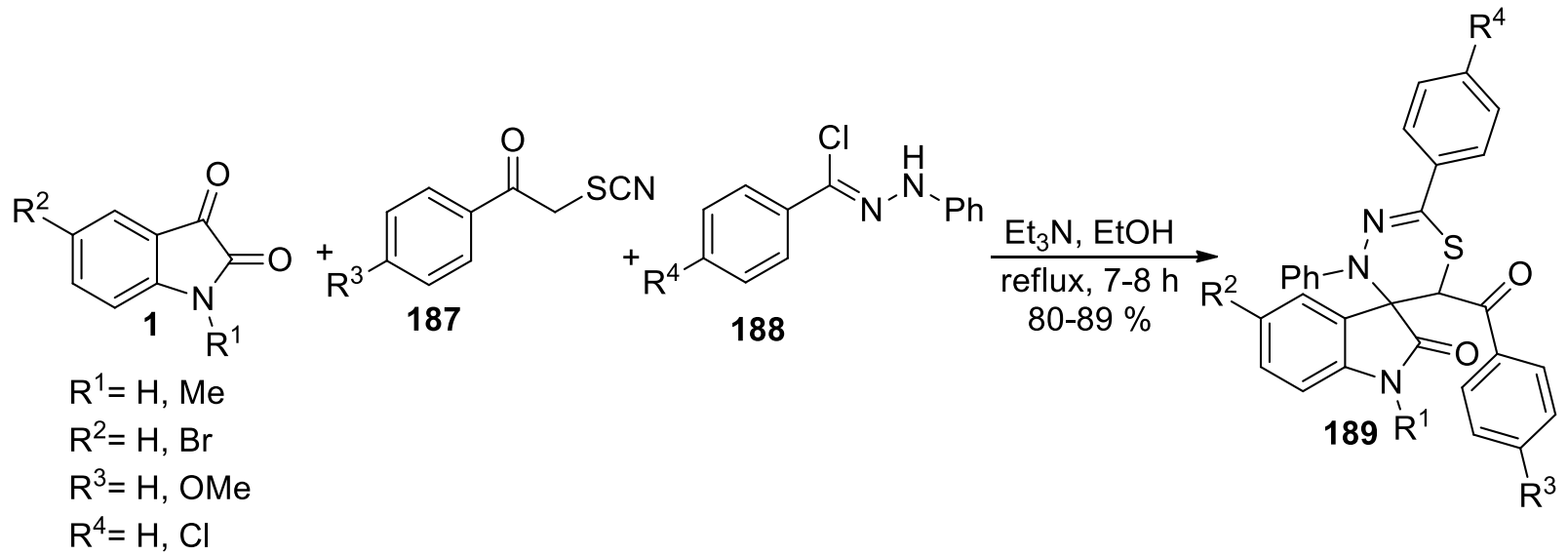

\section{Scheme 73}

Novel steroidal dihydropyridinyl spirooxindoles 192 were synthesized by the multicomponent reaction of isatins 1, pregnenolone (PREG) 190, malononitrile 156 and ammonium acetate 191 (Scheme 74)..$^{131}$ MTT assay indicated that some of these compounds exhibited moderate to excellent cytotoxic activity against the tested cancer cell lines. The cytotoxic activities varied greatly depending on the position and electronic nature of substituents on the isatin nucleus and $N$-benzyl moieties. 


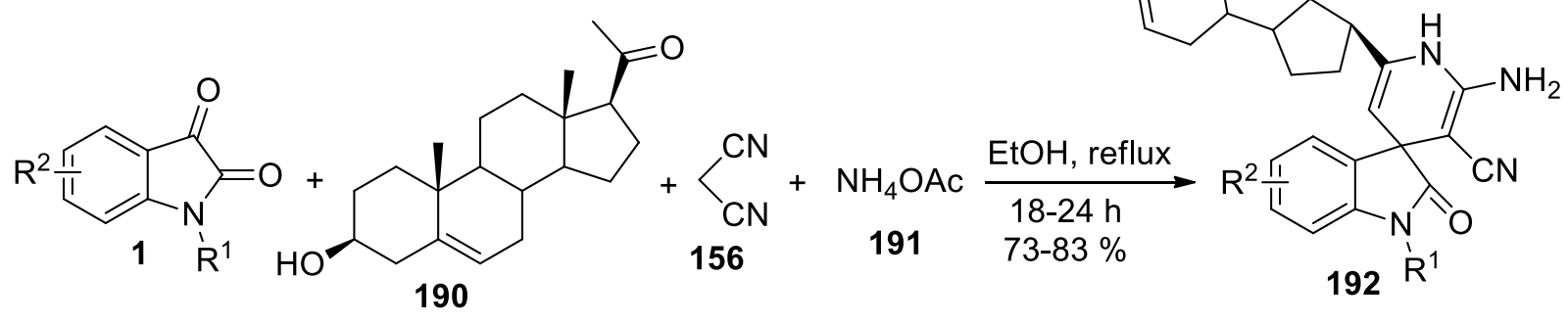

$\mathrm{R}^{1}=\mathrm{H}, 2-\mathrm{MeC}_{6} \mathrm{H}_{4} \mathrm{CH}_{2}, 3-\mathrm{MeC}_{6} \mathrm{H}_{4} \mathrm{CH}_{2}, 4-\mathrm{MeC}_{6} \mathrm{H}_{4} \mathrm{CH}_{2}, 2-\mathrm{ClC}_{6} \mathrm{H}_{4} \mathrm{CH}_{2}, 4-\mathrm{ClC}_{6} \mathrm{H}_{4} \mathrm{CH}_{2}$,

$3,4-\mathrm{Cl}_{2} \mathrm{C}_{6} \mathrm{H}_{3} \mathrm{CH}_{2}, 2-\mathrm{FC}_{6} \mathrm{H}_{4} \mathrm{CH}_{2}, 3-\mathrm{FC}_{6} \mathrm{H}_{4} \mathrm{CH}_{2}, 4-\mathrm{FC}_{6} \mathrm{H}_{4} \mathrm{CH}_{2}$, Propargyl

$\mathrm{R}^{2}=\mathrm{H}, 5-\mathrm{F}, 5-\mathrm{Cl}, 5-\mathrm{Br}, 7-\mathrm{Cl}$

\section{Scheme 74}

Rajanarendar et al. used $p$-toluene sulfonic acid ( $p$-TSA) as an efficient catalyst in the reaction of isatin derivatives 1, 1,3-indanedione 165 and 4-amino-3-methyl-5-styrylisoxazole 193 for the synthesis of isoxazolylspiro [diindeno[1,2- $b ; 2^{\prime}, 1^{\prime}$-e $]$ pyridine-11,3'-indoline]-2',10,12-triones 194 (Scheme 75). ${ }^{132}$<smiles>[R]c1cc([R4])c2c(c1)C(=O)C(=[O+])N2</smiles>

$\mathrm{R}^{1}=\mathrm{H}, \mathrm{Me}, \mathrm{Cl}$

$\mathrm{R}^{2}=\mathrm{H}, \mathrm{Me}, \mathrm{Cl}, \mathrm{Br}, \mathrm{OMe}$

$\mathrm{Ar}=\mathrm{C}_{6} \mathrm{H}_{5}, 4-\mathrm{MeC}_{6} \mathrm{H}_{4}, 4-\mathrm{MeOC}_{6} \mathrm{H}_{4}, 2-\mathrm{BrC}_{6} \mathrm{H}_{4}, 2-\mathrm{ClC}_{6} \mathrm{H}_{4}, 2-\mathrm{MeOC}_{6} \mathrm{H}_{4}$<smiles>[R]c1cc([R1])c2c(c1)C1(C(=O)N2)c2ccccc2-c2c1c1c(n2-c2c(C)noc2/C=C/[Al])-c2ccccc2C1=O</smiles>

\section{Scheme 75}

Oxalic acid dihydrate: proline (LTTM) promoted the synthesis of spiro[diindeno[1,2- $\left.b: 2^{\prime}, 1^{\prime}-e\right]$ pyridine11,3'-indoline]-triones 195 in the reaction of isatins 1, 1,3-indanedione 165 and anilines 55 as starting materials (Scheme 76). ${ }^{133}$

Shaabani et al. studied the synthesis of fully substituted naphthyridines 199 through the domino reaction of isatin derivatives 1, diamines 196, 1,1-bis(methylthio)-2-nitroethylene 197 and 2-aminoprop-1-ene-1,1,3tricarbonitrile 198 using a deep eutectic solvent (DES) (Scheme 77). ${ }^{134}$ 


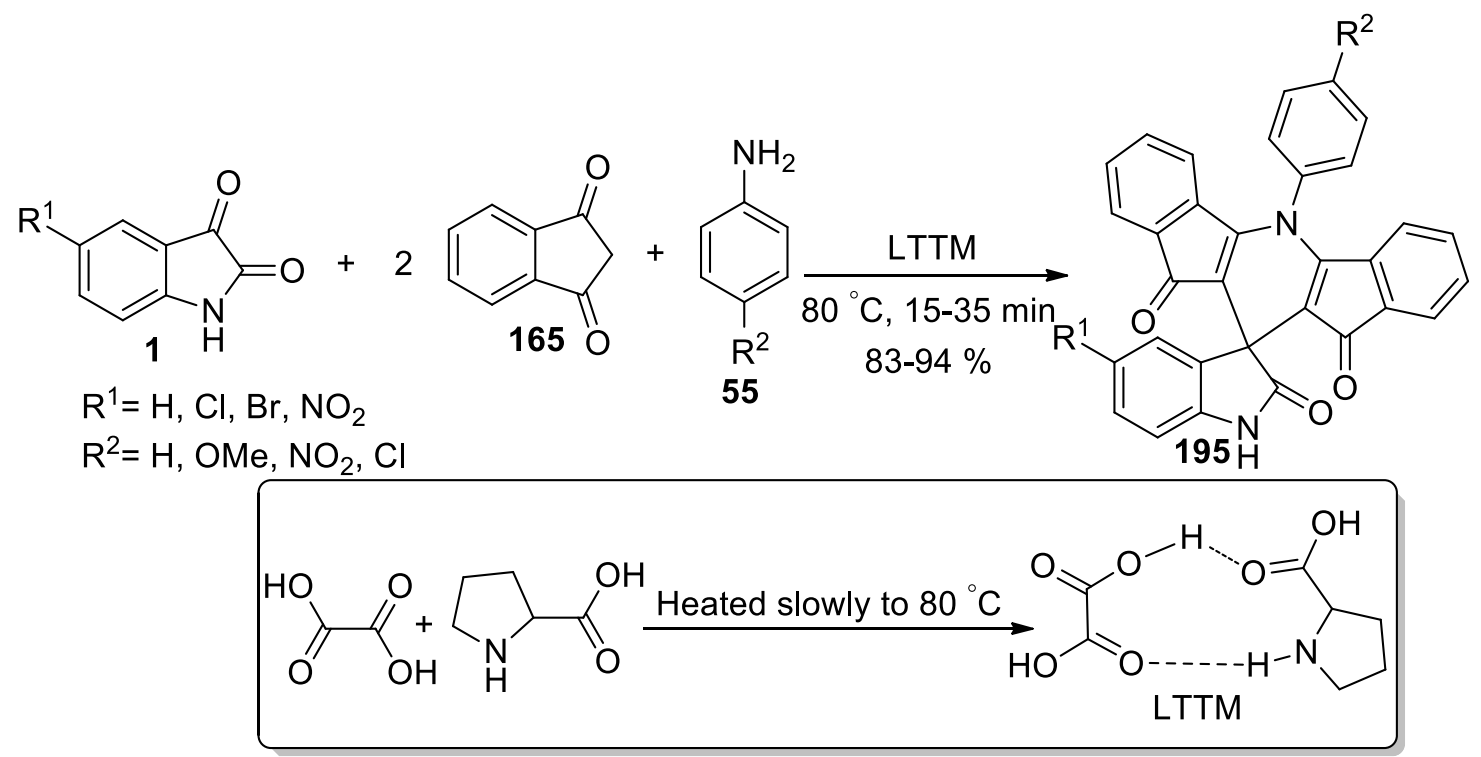

\section{Scheme 76}<smiles>[R]c1ccc2c(c1)C(=O)C(=[OH+])N2</smiles>

\section{Scheme 77}

Shrestha et al. reported a one-pot synthesis of biologically spiro[indoline-3,4'-pyrano[2,3-c]pyrazole] derivatives 200 using $\mathrm{CeO}_{2}$ nanoparticle-catalyzed four-component reaction of isatins $1, \beta$-ketoesters 167, phenylhydrazines 168 and malononitrile 156 in water (Scheme 78). ${ }^{135}$ In another study, $\mathrm{Fe}_{3} \mathrm{O}_{4} @ \mathrm{SiO}_{2}$ was used as the catalyst of this reaction. ${ }^{136}$

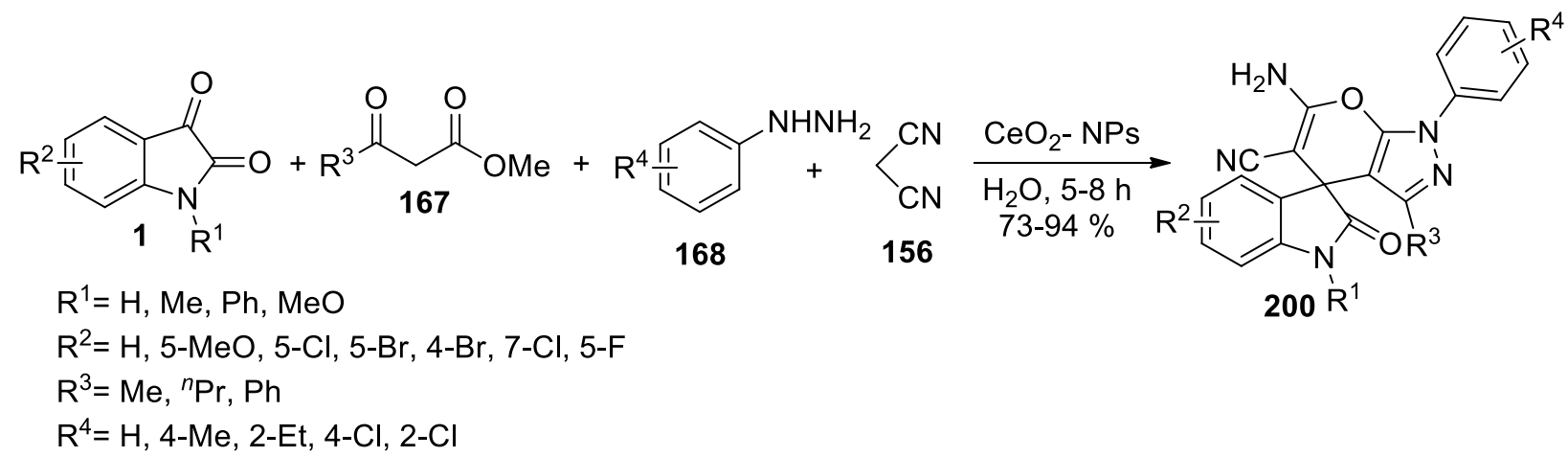

\section{Scheme 78}


The synthesis of 2-hydroxy-3-[(5-methyl-3-oxo-2-phenyl-2,3-dihydro-1H-pyrazol-4-yl)(phenyl)methyl]naphthalene-1,4-dione derivatives 202 has been developed through a one-pot, four-component reaction of isatin 1, 2-hydroxy-1,4-naphthoquinone 201, hydrazine 168 and $\beta$-ketoester 167 catalyzed by $\mathrm{MgCl}_{2}$ in ethylene glycol (Scheme 79). ${ }^{137}$

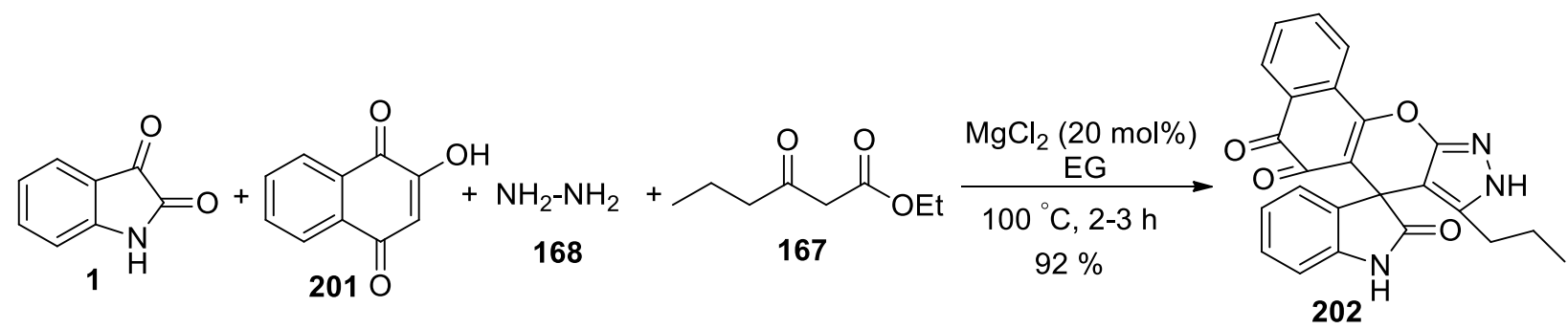

Scheme 79

\subsection{Seven-membered heterocycles}

Condensation of isatin 1 with a C,N-1,6-binucleophile generated in situ from o-aminobenzaldehyde 11 and 2methylindole 57 through a Mannich-type reaction was established for the synthesis of a quinoline-fused 1benzazepine derivative 203 (Scheme 80)..$^{138}$

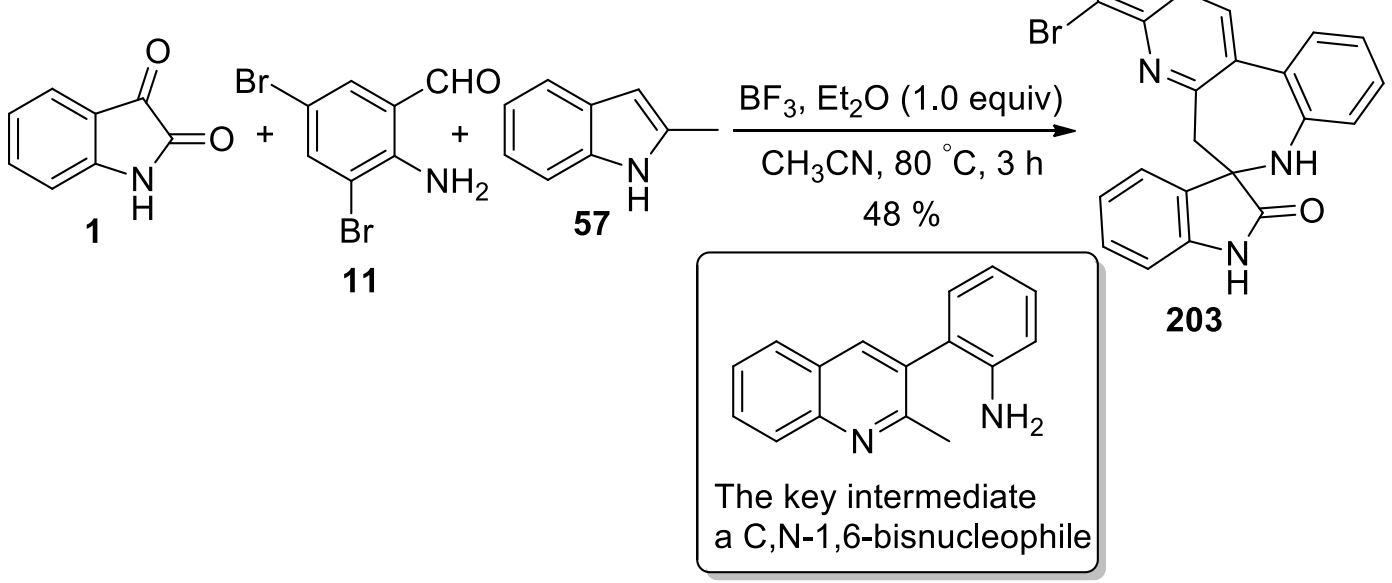

\section{Scheme 80}

\section{Synthesis of Isatin-based Spiro-fused Carbocyclic Frameworks}

Zhan et al. investigated the asymmetric annulation reactions of Morita-Baylis-Hillman carbonates, derived from isatins 71 and 2-alkylidene- $1 H$-indene-1,3(2H)-diones 165, catalyzed by various chiral Lewis bases, which resulted in a switch in chemo- and diastereoselectivity. While [2 +1$]$ reactions catalyzed by chiral tertiary amines, derived from cinchona alkaloids, produced densely substituted cyclopropanes 204, diastereodivergent 
[3 + 2] annulations generated bis(spirocycl)ic oxindoles 205 by employing either a chiral phosphine or a DMAPtype catalyst (Scheme 81)..$^{139}$

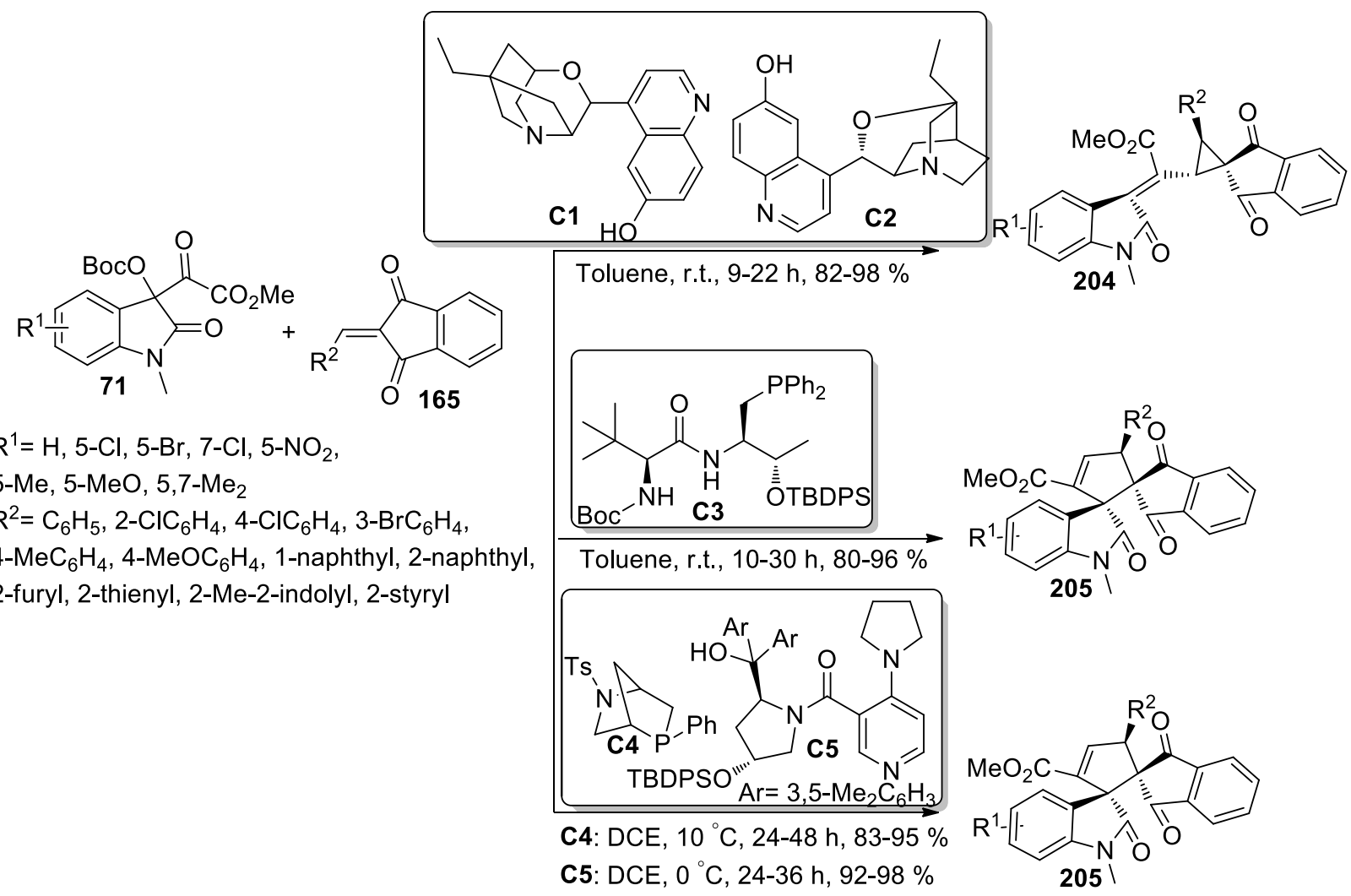

\section{Scheme 81}

Pepsin was used as a biocatalyst in the domino Knoevenagel/Michael/Michael reaction for the synthesis of spirooxindole derivatives in methanol. A wide range of isatins 1 and enones $\mathbf{8 3}$ in reaction with malononitrile 156 provided spirocyclic oxindoles 206 in yields of up to $99 \%$ and oxindoles 207 in trace yields with diastereoselectivity up to $>99: 1 \mathrm{dr}$ (Scheme82). ${ }^{140}$ Reactions with isatins bearing an electron-donating group in the 5-position gave better yields than those bearing a strong electron-withdrawing group in the 5-position. The position of substituents also had effects on the reaction yield. The isatins with a substituent in the 5position gave higher yields than those with a substituent in the 1- or 7-position.

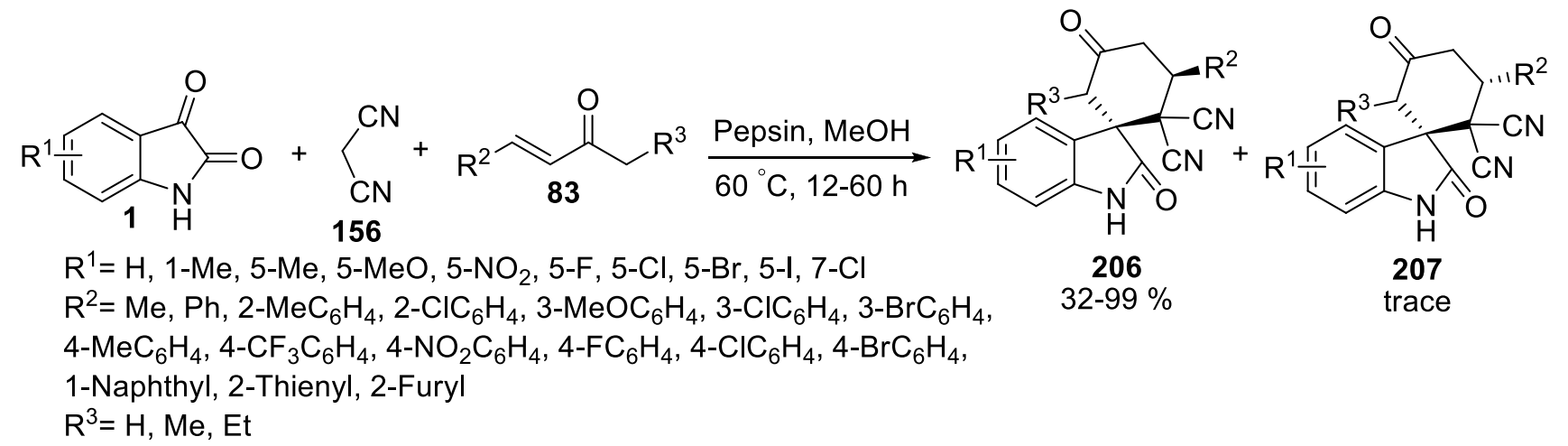

\section{Scheme 82}


Hegade and co-workers developed an organocatalyzed pseudo four-component reaction of isatin derivatives 1, cyclohexanone 208, and malononitrile 156 in the presence of a catalytic amount of DABCO for the synthesis of functionalized spirooxindoles 209 (Scheme 83). ${ }^{141}$

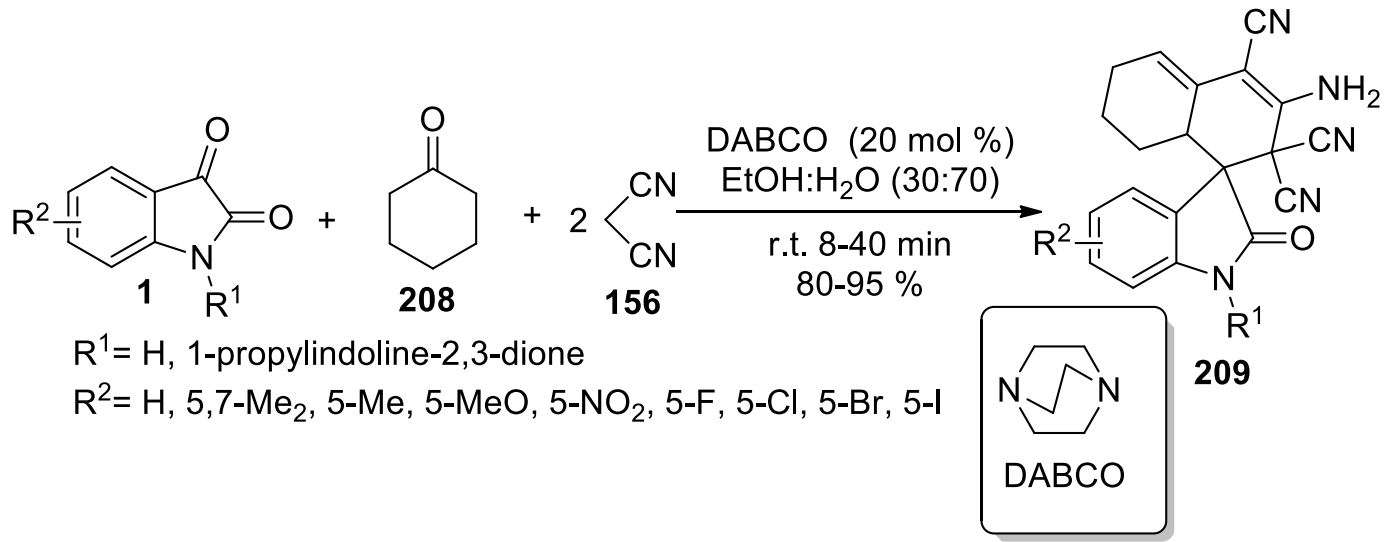

\section{Scheme 83}

\section{Miscellaneous Reactions}

From the reaction of isatin $\mathbf{1}$ and thiosemicarbazide $\mathbf{5 3}$ through multiple steps (involving the intermediates AE) a series of semicarbazones containing 1,3,4-thiadiazino and indole rings 210 were synthesized (Scheme 84). ${ }^{142}$ All the newly synthesized compounds were investigated for anticonvulsant activity.
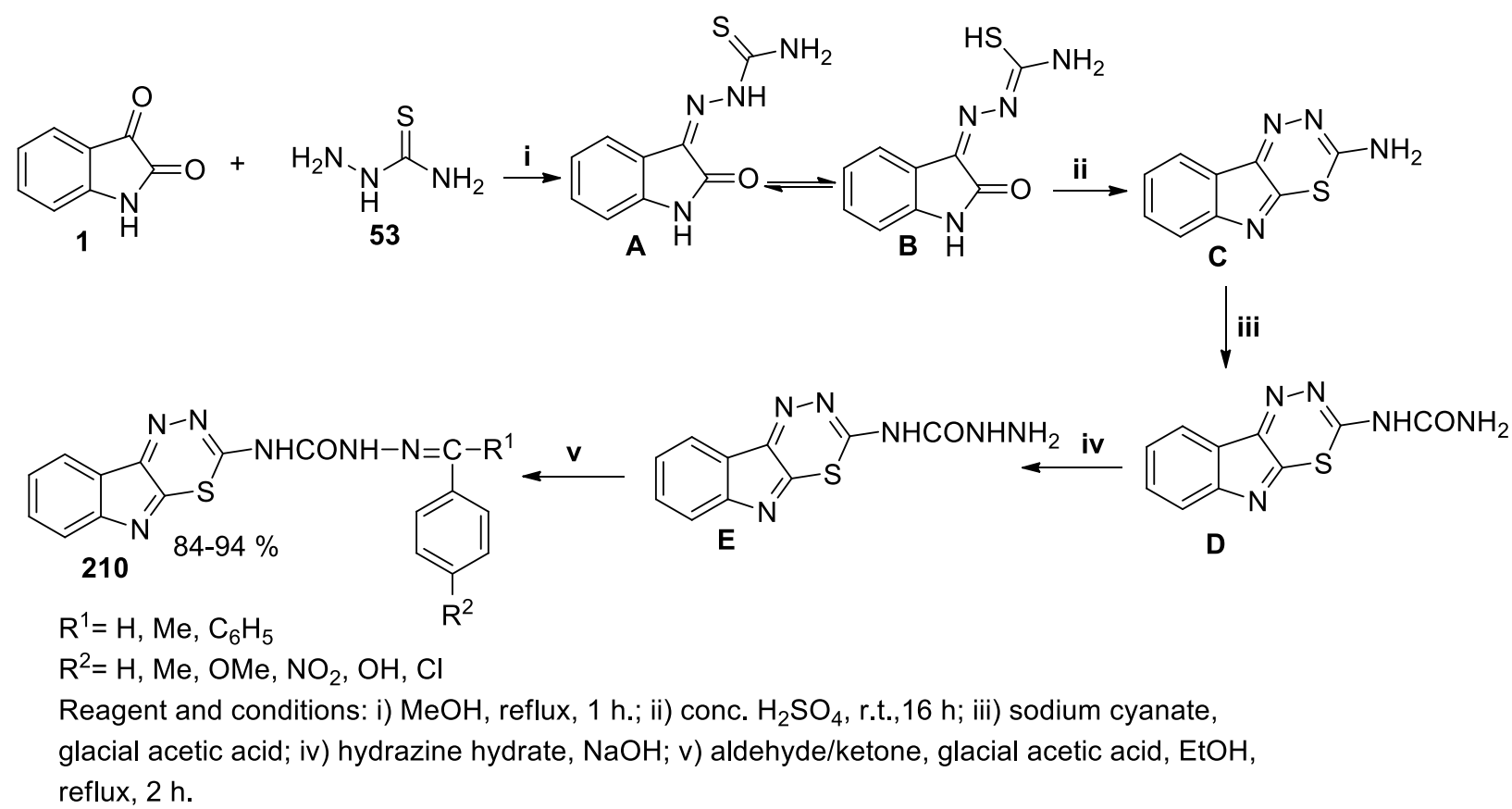

\section{Scheme 84}

A unique two-carbon ring expansion of isatins 1 has been achieved to conveniently construct the functionalized dibenzo[ $b, d]$ azepin-6-one scaffolds $\mathbf{2 1 2}$ while one carbon atom is from the $\mathrm{N}$-substituent of 
pyridinium bromide 211 and the other is from indene-1,3-dione 165. The possible reaction mechanism for two-carbon ring expansion has been shown in scheme 85. Pyridinium bromide $\mathbf{2 1 1}$ was first deprotonated to a pyridinium ylide under the basic conditions. The Michael addition of pyridinium ylide to the condensation product $\mathbf{A}$ resulted in the formation of zwitterion $\mathbf{B}$ without other regio-isomers, and this might have resulted from the more electron-deficient 3-position on the isatin 1 than the 2-position of indan-1,3-dione 165. The following proton transfer gave a new zwitterion $\mathbf{C}$, and the intramolecular nucleophilic addition of the carbon anion to the 2-carbonyl group of the isatinyl moiety afforded a cyclopropyl intermediate D. The less strong electron-withdrawing nature of $\mathrm{R}^{2}$ groups such as $p$-nitrobenzyl makes this transfer hard to occur, and this multi-component reaction stops at this stage. The re-opening of cyclopropane oxide $\mathbf{D}$ leads to the attack of the newly generated carbon anion on the carbonyl group in the indene-1,3-dione 165. The resulting cyclopropyl oxide $\mathbf{E}$ further re-opened and the removal of pyridine afforded cyclopropane $\mathbf{F}$. The following cyclopropane reorganized to the ring-expanded product 212 (Scheme 85). ${ }^{143}$

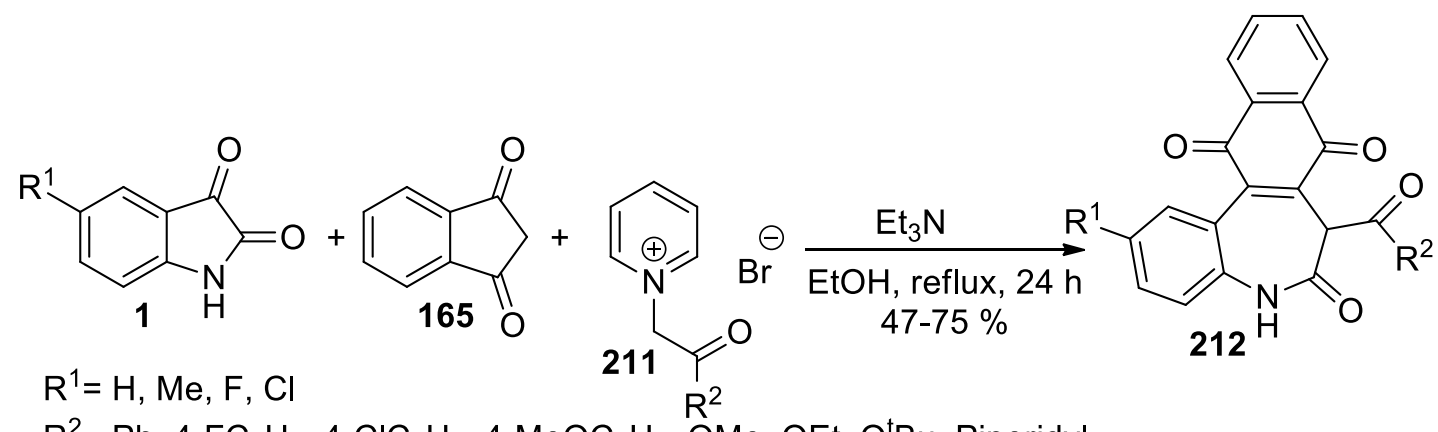

$\mathrm{R}^{2}=\mathrm{Ph}, 4-\mathrm{FC}_{6} \mathrm{H}_{4}, 4-\mathrm{ClC}_{6} \mathrm{H}_{4}, 4-\mathrm{MeOC}_{6} \mathrm{H}_{4}$, OMe, OEt, O'Bu, Piperidyl

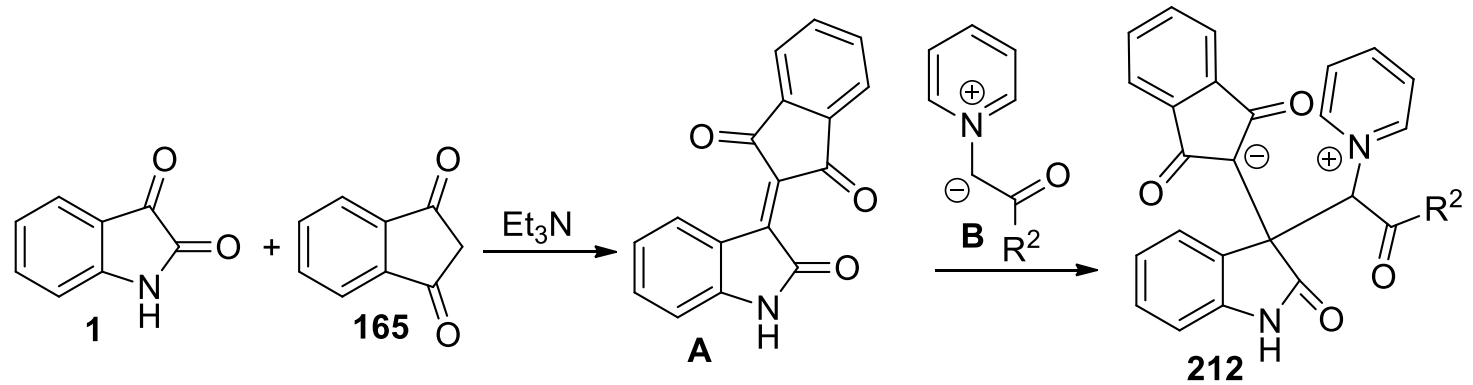<smiles>[R]C(=O)C1C(=O)Nc2ccccc2C2=C1C(=O)c1ccccc1C2=O</smiles>

\section{Scheme 85}


The spiro[pyrrolo-4,10'-indeno[1,2-b]quinolin]-3-carboxylate compounds $\mathbf{2 1 3}$ were obtained from the reaction of isatin derivatives 1 , amines 55, $\beta$-ketoesters 167 and indane-1,3-dione 165 with activated alumina balls (3-5 mm diameter) as a catalyst under neat reaction conditions (Scheme 86). ${ }^{144}$ Except for $n$-butylamine (which resulted in lower yields), the products were obtained in good to excellent yields (72-92\%) whether there is an electron-donating or -withdrawing substituent on the aromatic ring. The substituted isatin derivatives with $\mathrm{Cl}$ and $\mathrm{Br}$ at the 5-position also reacted efficiently to give high yields.

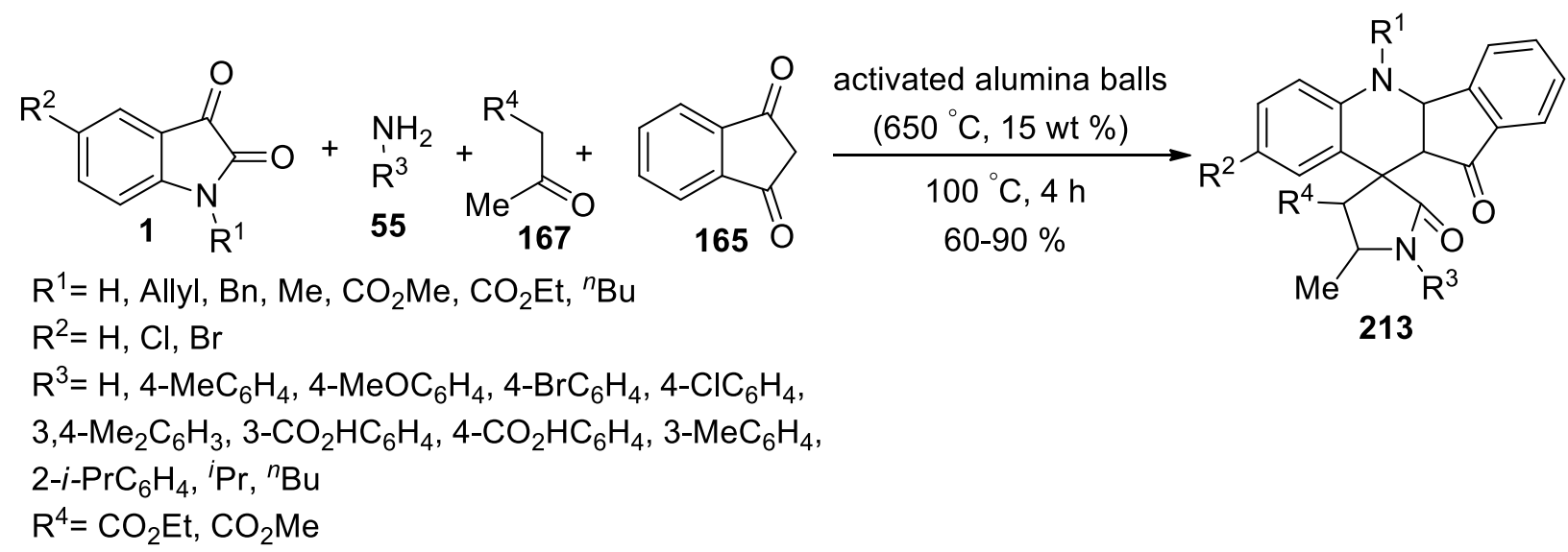

\section{Scheme 86}

\section{Conclusions}

Isatin is one of the important heterocyclic structures with special significance for the synthesis of organic compounds. Schiff bases of isatin, 3,3-disubstituted oxindoles and spirooxindoles are some important structures that can be synthesized using isatin as an starting material. More importantly, most of these compounds exhibit biological and pharmaceutical activities. In recent years, isatin has been widely used in the synthesis of a variety of organic compounds. Due to the widespread use of isatin in organic reactions and pursuant to our previous studies, herein we have an overview of recent applications of isatin in the synthesis of organic compounds up to June 2016.

\section{Acknowledgements}

We are grateful for financial support from the Research Council of Alzahra University.

\section{Abbreviations}

DABCO: diazabicyclooctane

DBU: diazabicycloundecene

DCE: dichloroethane

DCM: dichloromethane

DMF: dimethylformamide

EG: ethylene glycol

MTBE: methyl tertiary-butyl ether 
PEG: polyethylene glycol

TBAF: tetrabutylammonium fluoride

TBSOTf: tert-butyldimethylsilyl trifluoromethanesulfonate

TFA: trifluoroacetic acid

THF: tetrahydrofuran

\section{References}

1. Erdmann, O. L. J. Prakt. Chem. 1840, 19, 321.

http://dx.doi.org/10.1002/ardp.18400720604

2. Laurent, A. Ann. Chim. Phys. 1840, 3, 393.

3. Jarrahpour, A. A.; Khalili, D. Molbank 2005, 4, M437.

http://dx.doi.org/10.3390/M437

4. Fortt, R.; Smith, G.; Awais, R. O.; Luthra, S. K.; Aboagye, E. O. Nucl. Med. Biol. 2012, 39, 1000.

http://dx.doi.org/10.1016/j.nucmedbio.2012.03.004

5. Ermut, G.; Karal, N.; Cetin, I.; Topcul, M.; Birteksoz, S. Marmara Pharm. J. 2013, 17, 147. http://dx.doi.org/10.12991/201317383

6. Kumar, M.; Ramasamy, K.; Mani, V.; Mishra, R. K.; Majeed, A. B. A.; Clercq, E. D.; Narasimhan, B. Arabian J. Chem. 2014, 7, 396.

http://dx.doi.org/10.1016/j.arabjc.2012.12.005

7. Havrylyuk, D.; Zimenkovsky, B.; Vasylenko, O.; Gzella, A.; Lesyk, R. J. Med. Chem. 2012, 55, 8630. http://dx.doi.org/10.1021/jm300789g

8. Kumar, S. B.; Ravinder, M.; Kishore, G.; Rao, V. J.; Yogeeswari, P.; Sriram, D. Med. Chem. Res. 2014, 23, 1934.

http://dx.doi.org/10.1007/s00044-013-0787-x

9. Kumar, K.; Kremer, S. C.; Kremer, L.; Gueerardel, Y.; Biot, C.; Kumar, V. Organomet. 2013, $32,5713$. http://dx.doi.org/10.1021/om301157z

10. Mondal, P.; Jana, S.; Balaji, A.; Ramakrishna, R.; Kanthal, L. J. Young Pharm. 2013, 4, 38.

http://dx.doi.org/10.4103/0975-1483.93574

11. Raj, R.; Singh, P.; Singh, P.; Gut, J.; Rosenthal, P. J.; Kumar, V. Eur. J. Med. Chem. 2013, 62, 590.

http://dx.doi.org/10.1016/j.ejmech.2013.01.032

12. Paul, B. K.; Ray, D.; Guchhait, N. Phys. Chem. Chem. Phys. 2013, 15, 1275.

http://dx.doi.org/10.1039/C2CP42539D

13. Kiran, G.; Maneshwar, T.; Rajeshwar, Y.; Sarangapani, M. J. Chem. 2013, 2013, 1. http://dx.doi.org/10.1155/2013/192039

14. Zhou, F.; Liu, Y.-L.; Zhou, J. Adv. Synth. Catal. 2010, 352, 1381.

http://dx.doi.org/10.1002/adsc.201000161

15. Peddibhotla, S. Curr. Bioact. Compd. 2009, 5, 20.

http://dx.doi.org/10.2174/157340709787580900

16. Badillo, J. J.; Hanhan, N. V.; Franz, A. K. Curr. Opin. Drug Discovery Dev. 2010, 13, 758.

17. Singh, G. S.; Desta, Z. Y. Chem. Rev. 2012, 112, 6104.

http://dx.doi.org/10.1021/cr300135y

18. Borad, M. A.; Bhoi, M. N.; Prajapati, N. P.; Patel, H. D. Synth. Commun. 2014, 44, 897.

http://dx.doi.org/10.1080/00397911.2013.843196 
19. Borad, M. A.; Bhoi, M. N.; Prajapati, N. P.; Patel, H. D. Synth. Commun. 2014, 44, 1043. http://dx.doi.org/10.1080/00397911.2013.858361

20. Ball-Jones, N. R.; Badillo, J. J.; Franz, A. K. Org. Biomol. Chem. 2012, 10, 5165. http://dx.doi.org/10.1039/C2OB25184A

21. Flores, M.; Pena, J.; García, P. G.; Garrido, N. M.; Díez, D. Curr. Org. Chem. 2013, 17, 1957. http://dx.doi.org/10.2174/13852728113179990092

22. Liu, Y.; Wang, H.; Wan, J. Asian J. Org. Chem. 2013, 2, 374. http://dx.doi.org/10.1002/ajoc.201200180

23. Mohammadi Ziarani, G.; Moradi, R.; Lashgari, N. Arkivoc 2016, (i), 1. http://dx.doi.org/10.3998/ark.5550190.p009.385

24. Lashgari, N.; Mohammadi Ziarani, G. Arkivoc 2012, (i), 277. http://dx.doi.org/10.3998/ark.5550190.0013.108

25. Mohammadi Ziarani, G.; Moradi, R.; Lashgari, N. Tetrahedron: Asymmetry 2015, 26, 517. http://dx.doi.org/10.1016/i.tetasy.2015.04.011

26. Yadav, G. D.; Singh, S. Tetrahedron: Asymmetry 2016, 27, 123. http://dx.doi.org/10.1016/i.tetasy.2015.12.005

27. Yadav, G. D.; Singh, S. Tetrahedron: Asymmetry 2016, 27, 463. http://dx.doi.org/10.1016/i.tetasy.2016.04.008

28. Sanjeeva Kumar, A.; Santosh Kumar, G.; Babu Nanubolu, J. RSC Adv. 2016, 6, 1705. http://dx.doi.org/10.1039/C5RA14714J

29. Huang, Y.; Huang, R.-Z.; Zhao, Y. J. Am. Chem. Soc. 2016, 138, 6571. http://dx.doi.org/10.1021/jacs.6b02372

30. Chen, Q.; Tang, Y.; Huang, T.; Liu, X.; Lin, L.; Feng, X. Angew. Chem., Int. Ed. 2016, 55, 5286. http://dx.doi.org/10.1002/anie.201600711

31. Singh, V. K.; Upadhyay, A.; Singh, R. K. P. Tetrahedron Lett. 2017, 58, 156. http://dx.doi.org/10.1016/j.tetlet.2016.11.124c

32. Pandey, G.; Khamrai, J. Asian J. Chem. 2016, 5, 621.

http://dx.doi.org/10.1002/ajoc.201600101

33. Xu, N.; Gu, D.-W.; Zi, J.; Wu, X.-Y.; Guo, X.-X. Org. Lett. 2016, 18, 2439. http://dx.doi.org/10.1021/acs.orglett.6b00971

34. Wang, G.; Liu, X.; Chen, Y.; Yang, J.; Li, J.; Lin, L.; Feng, X. ACS Catal. 2016, 6, 2482. http://dx.doi.org/10.1021/acscatal.6b00294

35. He, Q.; Zhan, G.; Du, W.; Chen, Y. C. Beilstein J. Org. Chem. 2016, 12, 309. http://dx.doi.org/10.3762/bjoc.12.33

36. Senwar, K. R.; Reddy, T. S.; Thummuri, D.; Sharma, P.; Naidu, V. G. M.; Srinivasulu, G.; Shankaraiah, N. Eur. J. Med. Chem. 2016, 118, 34. http://dx.doi.org/10.1016/j.ejmech.2016.04.025

37. Shaker, S. A.; Marzouk, M. I. Molecules 2016, 21, 155. http://dx.doi.org/10.3390/molecules21020155

38. Kondoh, A.; Takei, A.; Terada, M. Synlett 2016, 27, 1848. http://dx.doi.org/10.1055/s-0035-1561859

39. Nazish, M.; Jakhar, A.; Noor-ul, H. K.; Verma, S.; Kureshy, R. I.; Abdi, S. H.; Bajaj, H. C. Appl. Catal., A 2016, $515,116$. 
http://dx.doi.org/10.1016/j.apcata.2015.12.037

40. Su, L.; Xu, M.-H. Synthesis 2016, 48, 2595.

http://dx.doi.org/10.1055/s-0035-1561426

41. Menapara, T.; Choudhary, M. K.; Tak, R.; Kureshy, R. I.; Noor-ul, H. K.; Abdi, S. H. J. Mol. Catal. A: Chem. 2016, 421, 161.

http://dx.doi.org/10.1016/j.molcata.2016.05.021

42. Amr, F. I.; Vila, C.; Blay, G.; Muñoz, M. C.; Pedro, J. R. Adv. Synth. Catal. 2016, 358, 1583. http://dx.doi.org/10.1002/adsc.201600036

43. Vila, C.; Amr, F. I.; Blay, G.; Muñoz, M. C.; Pedro, J. R. Chem. Asian J. 2016, 11, 1532. http://dx.doi.org/10.1002/asia.201600325

44. Yanagisawa, A.; Yamafuji, S.; Sawae, T. Synlett 2016, 27, 2019.

http://dx.doi.org/10.1055/s-0035-1561450

45. Chen, T.; Cai, C. Org. Biomol. Chem. 2016, 14, 5019. http://dx.doi.org/10.1039/C60B00551A

46. He, Q.; Wu, L.; Kou, X.; Butt, N.; Yang, G.; Zhang, W. Org. Lett. 2016, 18, 288. http://dx.doi.org/10.1021/acs.orglett.5b03458

47. Li, X.; Su, J.; Liu, Z.; Zhu, Y.; Dong, Z.; Qiu, S.; Wang, J.; Lin, L.; Shen, Z.; Yan, W. Org. Lett. 2016, 18, 956. http://dx.doi.org/10.1021/acs.orglett.5b03566

48. Elghamry, I.; Al-Faiyz, Y. Tetrahedron Lett. 2016, 57, 110.

http://dx.doi.org/10.1016/i.tetlet.2015.11.070

49. Yogi, P.; Ashid, M.; Hussain, N.; Khan, S.; Joshi, A. Asian J. Chem. 2016, 28, 927. http://dx.doi.org/10.14233/ajchem.2016.19603

50. Kumar, M.; Kaur, B. P.; Chimni, S. S. Chem. Eur. J. 2016, 22, 9948.

http://dx.doi.org/10.1002/chem.201601222

51. Sharma, S.; Banerjee, B.; Brahmachari, G.; Kant, R.; Gupta, V. K. Crystallogr. Rep. 2016, 61, 225. http://dx.doi.org/10.1107/S2052520616005060

52. Nikoofar, K.; Khalili, Z. Z. Naturforsch. B Chem. Sci. 2016, 71, 31.

http://dx.doi.org/10.1515/znb-2015-0111

53. Hassani, H.; Nasseri, M. A.; Zakerinasab, B.; Rafiee, F. Appl. Organomet. Chem. 2016, 30, 408. http://dx.doi.org/10.1002/aoc.3447

54. Cheng, D.; Ling, F.; Zheng, C.; Ma, C. Org. Lett. 2016, 18, 2435. http://dx.doi.org/10.1021/acs.orglett.6b00964

55. Bejjam, M. B.; Kumar, G. S.; Swetha, A.; Meshram, H. RSC Adv. 2016, 6, 13820. http://dx.doi.org/10.1039/C5RA24127H

56. Williams, R. M.; Cox, R. J. Acc. Chem. Res. 2003, 36, 127. http://dx.doi.org/10.1021/ar020229e

57. Cui, C.-B.; Kakeya, H.; Osada, H. J. Antibiot. 1996, 49, 832. http://dx.doi.org/10.7164/antibiotics.49.832

58. Fischer, C.; Meyers, C.; Carreira, E. M. Helv. Chim. Acta 2000, 83, 1175. http://dx.doi.org/10.1002/1522-2675(20000607)83:6<1175::AID-HLCA1175>3.0.CO;2-D

59. Alper, P. B.; Meyers, C.; Lerchner, A.; Siegel, D. R.; Carreira, E. M. Angew. Chem., Int. Ed. 1999, $38,3186$. http://dx.doi.org/10.1002/(SICI)1521-3773(19991102)38:21<3186::AID-ANIE3186>3.0.CO;2-E

60. Ashimori, A.; Bachand, B.; Overman, L. E.; Poon, D. J. J. Am. Chem. Soc. 1998, 120, 6477. 
http://dx.doi.org/10.1021/ja980786p

61. Hajra, S.; Aziz, S. M.; Jana, B.; Mahish, P.; Das, D. Org. Lett. 2016, 18, 532.

http://dx.doi.org/10.1021/acs.orglett.5b03564

62. Pace, V.; Castoldi, L.; Mamuye, A. D.; Langer, T.; Holzer, W. Adv. Synth. Catal. 2016, 358, 172. http://dx.doi.org/10.1002/adsc.201500840

63. Wang, K.-K.; Jin, T.; Huang, X.; Ouyang, Q.; Du, W.; Chen, Y.-C. Org. Lett. 2016, 18, 872. http://dx.doi.org/10.1021/acs.orglett.6b00189

64. Zhao, B.-L.; Du, D.-M. Chem. Commun. 2016, 52, 6162.

http://dx.doi.org/10.1039/C6CC00705H

65. Zhao, K.; Zhi, Y.; Li, X.; Puttreddy, R.; Rissanen, K.; Enders, D. Chem. Commun. 2016, 52, 2249. http://dx.doi.org/10.1039/C5CC10057G

66. Kumar, K.; Sankar, M. G.; Garcia-Castro, M.; Golz, C.; Strohman, C. RSC Adv. 2016, 6, 56537. http://dx.doi.org/10.1039/C6RA12387B

67. Cheng, P.; Guo, W.; Chen, P.; Liu, Y.; Du, X.; Li, C. Chem. Commun. 2016, 52, 3418. http://dx.doi.org/10.1039/C5CC10292H

68. Cui, H.-L.; Chouthaiwale, P. V.; Yin, F.; Tanaka, F. Org. Biomol. Chem. 2016, 14, 1777. http://dx.doi.org/10.1039/C5OB02393A

69. Cui, H. L.; Chouthaiwale, P. V.; Yin, F.; Tanaka, F. Asian J. Org. Chem. 2016, 5, 153. http://dx.doi.org/10.1002/ajoc.201500412

70. Rong, X.; Yao, H.; Xia, W.; Du, Y.; Zhou, Y.; Liu, H. ACS Comb. Sci. 2016, 18, 220. http://dx.doi.org/10.1021/acscombsci.5b00197

71. Zhu, L.; Yu, C.; Li, T.; Wang, Y.; Lu, Y.; Wang, W.; Yao, C. Org. Biomol. Chem. 2016, 14, 1485. http://dx.doi.org/10.1039/C5OB02160J

72. Han, J. L.; Chang, C. H. Chem. Commun. 2016, 52, 2322. http://dx.doi.org/10.1039/C5CC08883F

73. Li, Y.; Hu, Y.; Zhang, S.; Sun, J.; Li, L.; Zha, Z.; Wang, Z. J. Org. Chem. 2016, 81, 2993. http://dx.doi.org/10.1021/acs.joc.5b02780

74. Mane, M. M.; Pore, D. M. J. Chem. Sci. 2016, 128, 657. http://dx.doi.org/10.1007/s12039-016-1047-7

75. Kumarswamyreddy, N.; Kesavan, V. Org. Lett. 2016, 18, 1354. http://dx.doi.org/10.1021/acs.orglett.6b00287

76. Wang, S.; Jiang, Y.; Wu, S.; Dong, G.; Miao, Z.; Zhang, W.; Sheng, C. Org. Lett. 2016, 18, 1028. http://dx.doi.org/10.1021/acs.orglett.6b00155

77. Kumar, D.; Sharma, L. K.; Sharma, K.; Jain, R. J. Heterocycl. Chem. 2017, 54, 570. http://dx.doi.org/10.1002/jhet.2623

78. Liu, J.-Y.; Lu, H.; Li, C.-G.; Liang, Y.-M.; Xu, P.-F. Synlett 2016, 27, 1287.

http://dx.doi.org/10.1055/s-0035-1560600

79. Domling, A.; Wang, W.; Wang, K. Chem. Rev. 2012, 112, 3083. http://dx.doi.org/10.1021/cr100233r

80. González-López, M.; Shaw, J. T. Chem. Rev. 2009, 109, 164. http://dx.doi.org/10.1021/cr8002714

81. Rotstein, B. H.; Zaretsky, S.; Rai, V.; Yudin, A. K. Chem. Rev. 2014, 114, 8323. http://dx.doi.org/10.1021/cr400615v 
82. Sunderhaus, J. D.; Martin, S. F. Chem. Eur. J. 2009, 15, 1300.

http://dx.doi.org/10.1002/chem.200802140

83. Guillena, G.; Ramon, D. J.; Yus, M. Tetrahedron: Asymmetry 2007, 18, 693.

http://dx.doi.org/10.1016/i.tetasy.2007.03.002

84. Liu, H.; Dou, G.; Shi, D. J. Comb. Chem. 2010, 12, 292.

http://dx.doi.org/10.1021/cc900195t

85. Roy, T.; Thangaraj, M.; Gonnade, R. G.; Biju, A. Chem. Commun. 2016, 52, 9044.

http://dx.doi.org/10.1039/c6cc00057f

86. Parmar, B. D.; Sutariya, T. R.; Brahmbhatt, G. C.; Parmar, N. J.; Kant, R.; Gupta, V. K. J 2016, 81, 4955. http://dx.doi.org/10.1021/acs.joc.6b00107

87. Liu, X.-W.; Yao, Z.; Yang, J.; Chen, Z.-Y.; Liu, X.-L.; Zhao, Z.; Lu, Y.; Zhou, Y.; Cao, Y. Tetrahedron 2016, 72, 1364.

http://dx.doi.org/10.1016/i.tet.2016.01.029

88. Liu, X.-L.; Yang, C.; Zhang, W.-H.; Zhou, G.; Ma, X.-T.; Lin, B.; Zhang, M.; Zhou, Y.; Feng, T.-T. Tetrahedron Lett. 2016, 57, 1385.

http://dx.doi.org/10.1016/i.tetlet.2016.02.074

89. Sumesh, R. V.; Muthu, M.; Almansour, A. I.; Suresh Kumar, R.; Arumugam, N.; Athimoolam, S.; Jeya Yasmi Prabha, E. A.; Kumar, R. R. ACS Comb. Sci. 2016, 18, 262.

http://dx.doi.org/10.1021/acscombsci.6b00003

90. Cores, Á.; Estévez, V.; Villacampa, M.; Menéndez, J. C. RSC Adv. 2016, 6, 39433.

http://dx.doi.org/10.1039/C6RA06317A

91. Nayak, S.; K Mishra, S.; Bhakta, S.; Panda, P.; Baral, N.; Mohapatra, S.; S Purohit, C.; Satha, P. Lett. Org. Chem. 2016, 13, 11.

http://dx.doi.org/10.2174/1570178612666151030213735

92. George, R. F.; Panda, S. S.; Shalaby, E. S. M.; Srour, A. M.; Farag, I. S. A.; Girgis, A. S. RSC Adv. 2016, 6, 45434.

http://dx.doi.org/10.1039/C6RA07061B

93. Uma Rani, G.; Vivek Kumar, S.; Bharkavi, C.; Menéndez, J. C.; Perumal, S. ACS Comb. Sci. 2016, $18,337$. http://dx.doi.org/10.1021/acscombsci.6b00011

94. Mathusalini, S.; Arasakumar, T.; Lakshmi, K.; Lin, C.-H.; Mohan, P. S.; Ramnath, M. G.; Thirugnanasampandan, R. New J. Chem. 2016, 40, 5164.

http://dx.doi.org/10.1039/c6nj00534a

95. Hamama, W. S.; Hassanien, A. E.; El-Fedawy, M. G.; Zoorob, H. H. J. Heterocycl. Chem. 2017, $54,859$. http://dx.doi.org/10.1002/ihet.2646

96. Sankar, U.; Surya Kumar, C. V.; Subramanian, V.; Balasubramanian, K. K.; Mahalakshimi, S. J. Org. Chem. 2016, 81, 2340.

http://dx.doi.org/10.1021/acs.joc.5b02845

97. Ramesh, P.; Rao, K. S.; Trivedi, R.; Kumar, B. S.; Prakasham, R.; Sridhar, B. RSC Adv. 2016, 6, 26546. http://dx.doi.org/10.1039/C6RA00613B

98. Shi, G.; He, X.; Shang, Y.; Xie, M. RSC Adv. 2016, 6, 10412. http://dx.doi.org/10.1039/c5ra23860a

99. Wang, Y.-M.; Zhang, H.-H.; Li, C.; Fan, T.; Shi, F. Chem. Commun. 2016, 52, 1804. http://dx.doi.org/10.1039/C5CC07924A 
100. Safaei-Ghomi, J.; Zahedi, S. Tetrahedron Lett. 2016, 57, 1071.

http://dx.doi.org/10.1016/j.tetlet.2016.01.073

101. Preetam, A.; Nath, M. Tetrahedron Lett. 2016, 57, 1502.

http://dx.doi.org/10.1016/j.tetlet.2016.02.079

102. Rajeswari, M.; Kumari, S.; Khurana, J. M. RSC Adv. 2016, 6, 9297. http://dx.doi.org/10.1039/C5RA26093K

103. Mali, P. R.; Rao, L. C.; Bangade, V. M.; Shirsat, P. K.; George, S. A.; Babu, N. J.; Meshram, H. M. New J. Chem. 2016, 40, 2225.

http://dx.doi.org/10.1039/C5NJ02126J

104. Kumari, S.; Singh, H.; Khurana, J. M. Tetrahedron Lett. 2016, 57, 3081.

http://dx.doi.org/10.1016/j.tetlet.2014.11.046

105. Maryamabadi, A.; Hasaninejad, A.; Nowrouzi, N.; Mohebbi, G.; Asghari, B. Bioorg. Med. Chem. 2016, 24, 1408.

http://dx.doi.org/10.1016/i.bmc.2016.02.019

106. Shakibaei, G. I.; Bazgir, A. RSC Adv. 2016, 6, 22306.

http://dx.doi.org/10.1039/C6RA00869K

107. Mohammadi Ziarani, G.; Aleali, F.; Lashgari, N.; Badiei, A. R. Iran. J. Chem. Chem. Eng. 2016, 35, 17.

108. Mohammadi Ziarani, G.; Asadi, S.; Badiei, A. R.; Sharifi, A.; Amanlou, M. Iran. J. Pharm. Res. 2016, $15,55$.

109. Mohammadi Ziarani, G.; Hassanzadeh, Z.; Gholamzadeh, P.; Soorki, A. A. Rev. Roum. Chim. 2016, 61, 77.

110. Sagir, H.; Rai, P.; Tiwari, S.; Siddiqui, I. J. Heterocycl. Chem. 2017, 54, 397.

http://dx.doi.org/10.1002/ihet.2596

111. Kumari, S.; Rajeswari, M.; Khurana, J. M. Synth. Commun. 2016, 46, 387. http://dx.doi.org/10.1080/00397911.2016.1141427

112. Nalini, G.; Jayachandramani, N.; Thanikachalam, V.; Jayabharath, J.; Manikandan, G.; Suresh, R. Can. Chem. Trans. 2016, 4, 62.

http://dx.doi.org/10.13179/canchemtrans.2016.04.01.0248

113. Kefayati, H.; Bazargard, S. J.; Vejdansefat, P.; Shariati, S.; Kohankar, A. M. Dyes Pigm. 2016, $125,309$. http://dx.doi.org/10.1016/j.dyepig.2015.10.034

114. Shi, R.-G.; Yan, C.-G. Chin. Chem. Lett. 2016, 27, 575.

http://dx.doi.org/10.1016/i.cclet.2016.02.016

115. Niknam, K.; Khataminejad, M.; Zeyaei, F. Tetrahedron Lett. 2016, 57, 361. http://dx.doi.org/10.1016/i.tetlet.2015.12.034

116. Keshavarz, M. J. Iran. Chem. Soc. 2016, 13, 553.

http://dx.doi.org/10.1007/s13738-015-0765-y

117. Ramadoss, H.; Saravanan, D.; Sudhan, S. P. N.; Sheik Mansoor, S. Der Pharma Chemica 2016, 8, 94.

118. Molla, A.; Hussain, S. RSC Adv. 2016, 6, 5491.

http://dx.doi.org/10.1039/C5RA21969H

119. Garcia-Garcia, P.; Moreno, J. M.; Diaz, U.; Bruix, M.; Corma, A. Nat. Commun. 2016, 7, 10835. http://dx.doi.org/10.1038/ncomms10835

120. Padvi, S. A.; Tayade, Y. A.; Wagh, Y. B.; Dalal, D. S. Chin. Chem. Lett. 2016, 27, 714. http://dx.doi.org/10.1016/i.cclet.2016.01.016

121. Molla, A.; Hussain, S. Synfacts 2016, 12, 0426.

http://dx.doi.org/10.1055/s-0035-1561789 
122. Rashidi, A.; Tavakoli, Z.; Tarak, Y.; Khodabakhshi, S.; Abbasabadi, M. K. J. Chin. Chem. Soc. 2016, 63, 399. http://dx.doi.org/10.1002/iccs.201500508

123. Elinson, M. N.; Ryzhkov, F. V.; Zaimovskaya, T. A.; Egorov, M. P. Monatsh. Chem. 2016, 147, 755. http://dx.doi.org/10.1007/s00706-015-1617-2

124. Baghernejad, M.; Khodabakhshi, S.; Tajik, S. New J. Chem. 2016, 40, 2704. http://dx.doi.org/10.1039/C5NJ03027G

125. Brahmachari, G.; Banerjee, B. Asian J. Org. Chem. 2016, 5, 271. http://dx.doi.org/10.1002/ajoc.201500465

126. Moosavi-Zare, A. R.; Zolfigol, M. A.; Noroozizadeh, E.; Moratab, R. S.; Zarei, M. J. Mol. Catal. A: Chem. 2016, 420, 246. http://dx.doi.org/10.1016/j.molcata.2016.04.021

127. Stucchi, M.; Lesma, G.; Meneghetti, F.; Rainoldi, G.; Sacchetti, A.; Silvani, A. J. Org. Chem. 2016, 81, 1877. http://dx.doi.org/10.1021/acs.joc.5b02680

128. Mishra, K.; Basavegowda, N.; Lee, Y. R. RSC Adv. 2016, 6, 27974. http://dx.doi.org/10.1039/C6RA03883B

129. Maloo, P.; Roy, T. K.; Sawant, D. M.; Pardasani, R. T.; Salunkhe, M. M. RSC Adv. 2016, 6, 41897. http://dx.doi.org/10.1039/C6RA05322J

130. Alizadeh, A.; Moafi, L. Synlett 2016, 27, 595. http://dx.doi.org/10.1055/s-0035-1560905

131. Zhang, Y.-L.; Li, Y.-F.; Wang, J.-W.; Yu, B.; Y.-K., S.; Liu, H.-M. Steroids 2016, 109, 22. http://dx.doi.org/10.1016/j.steroids.2016.03.005

132. Rajanarendar, E.; Thirupathaiah, K.; Ramakrishna, S.; Nagaraju, D.; Kishore, B. J. Heterocycl. Chem. 2017, $54,889$. http://dx.doi.org/10.1002/jhet.2650

133. Chandam, D. R.; Mulik, A. G.; Patil, D. R.; Patravale, A. P.; Kumbhar, D. R.; Deshmukh, M. B. J. Mol. Liq. 2016, 219, 573.

http://dx.doi.org/10.1016/i.molliq.2016.02.101

134. Shaabani, A.; Hooshmand, S. E.; Tabatabaei, A. T. 2016, 57, 351. http://dx.doi.org/10.1016/j.tetlet.2015.12.017

135. Shrestha, R.; Sharma, K.; Lee, Y. R.; Wee, Y.-J. Mol. Divers. 2016, 20, 847. http://dx.doi.org/10.1007/s11030-016-9670-2

136. Alemi-Tameh, F.; Safaei-Ghomi, J.; Mahmoudi-Hashemi, M.; Teymuri, R. Res. Chem. Intermed. 2016, 42, 6391.

http://dx.doi.org/10.1007/s11164-016-2470-6

137. Fu, Z.; Qian, K.; Li, S.; Shen, T.; Song, Q. Tetrahedron Lett. 2016, 57, 1104. http://dx.doi.org/10.1016/j.tetlet.2016.01.089

138. Min, L.; Pan, B.; Gu, Y. Org. Lett. 2016, 18, 364. http://dx.doi.org/10.1021/acs.orglett.5b03287

139. Zhan, G.; Shi, M. L.; He, Q.; Lin, W. J.; Ouyang, Q.; Du, W.; Chen, Y. C. Angew. Chem., Int. Ed. 2016, 55, 2147.

http://dx.doi.org/10.1002/anie.201510825

140. He, Y.-H.; He, T.; Guo, J.-T.; Li, R.; Xiang, Y.; Yang, D.-C.; Guan, Z. Catal. Sci. Tech. 2016, 6, 2239. http://dx.doi.org/10.1039/C5CY00987A 
141. Hegade, P. G.; Chinchkar, S. D.; Pore, D. M. Monatsh. Chem. 2016, 147, 1243. http://dx.doi.org/10.1007/s00706-015-1637-y

142. Deshmukh, R.; S Thakur, A.; K Jha, A.; Kumar, P. Cent. Nerv. Syst. Agents Med. Chem. 2016, 16, 29. http://dx.doi.org/10.2174/1871524915666150623091716

143. Shi, R.-G.; Wang, X.-H.; Liu, R.; Yan, C.-G. Chem. Commun. 2016, 52, 6280.

http://dx.doi.org/10.1039/C6CC00525J

144. Mondal, A.; Banerjee, B.; Bhaumik, A.; Mukhopadhyay, C. Chem. Cat. Chem. 2016, 8, 1185. http://dx.doi.org/10.1002/cctc.v8.6

\section{Authors Biographies}

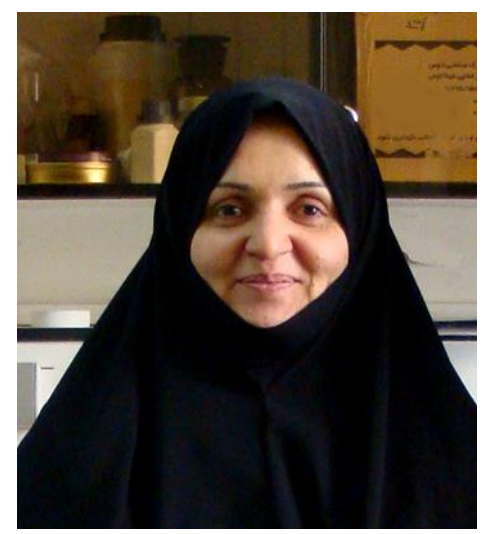

Ghodsi Mohammadi Ziarani was born in Iran, in 1964. She received her B.Sc. degree in Chemistry from Teacher Training University, Tehran, Iran, in 1987, her M.Sc. degree in Organic Chemistry from the Teacher Training University, Tehran, Iran, under the supervision of Professor Jafar Asgarin and Professor Mohammad Ali Bigdeli in 1991 and her Ph.D. degree in asymmetric synthesis (Biotransformation) from Laval University, Quebec, Canada under the supervision of Professor Chenevert, in 2000. She is Full Professor in the Science faculty of Alzahra University. Her research interests include organic synthesis, heterocyclic synthesis, asymmetric synthesis, natural products synthesis, synthetic methodology and applications of nanoheterogeneous catalysts in multicomponent reactions.

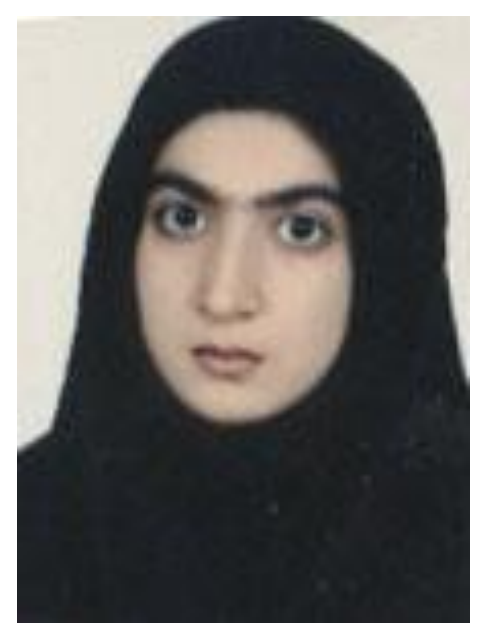


Razieh Moradi was born in 1990 in Lorestan, Iran. She obtained her B.Sc. degree in Chemistry from the University of Lorestan (2012) and her M.Sc. degree in Organic Chemistry at Alzahra University under the supervision of Dr Ghodsi Mohammadi Ziarani. She is currently Ph.D. student in Organic Chemistry at Alzahra University under the supervision of $\mathrm{Dr}$ Ghodsi Mohammadi Ziarani. Her research field is on the synthesis of heterocyclic compounds based on isatin and application of nano-heterogeneous catalysts in organic synthesis and multicomponent reactions.

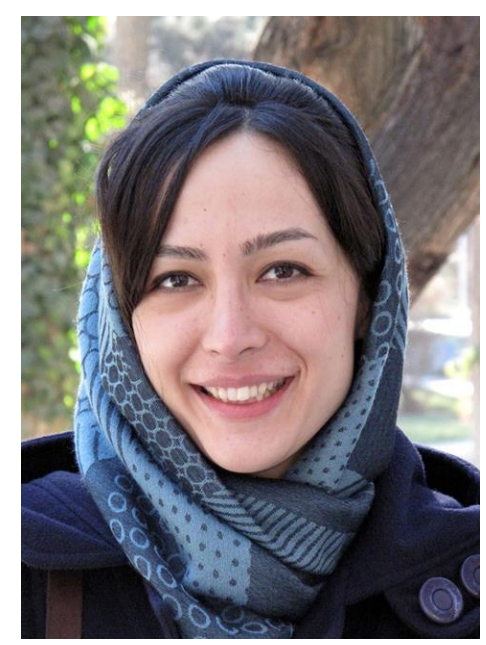

Negar Lashgari was born in 1985 in Tehran, Iran. She received her B.Sc. degree in Applied Chemistry from Teacher Training University, Tehran, Iran (2008) and her M.Sc. degree in Organic Chemistry at Alzahra University, Tehran, Iran (2011) under the supervision of Dr Ghodsi Mohammadi Ziarani. She is currently working towards her Ph.D. in Nano-Chemistry at University of Tehran under the supervision of Dr Alireza Badiei and Dr Ghodsi Mohammadi Ziarani. Her research field is synthesis and application of nanoheterogeneous catalysts in multicomponent reactions. 